\author{
UNIVERSIDADE DE SÃO PAULO \\ ESCOLA POLITÉCNICA \\ DEPARTAMENTO DE ENGENHARIA DE PRODUÇÃO
}

ANGELO VARANDAS JUNIOR

\title{
ESTUDO EXPLORATÓRIO NO DESENVOLVIMENTO DE NOVOS PRODUTOS EM EMPRESAS DO SEGMENTO DE AÇOS PLANOS DO SETOR SIDERÚRGICO: UMA ABORDAGEM NO PROJETO DO PROCESSO
}




\section{ESTUDO EXPLORATÓRIO NO DESENVOLVIMENTO DE NOVOS PRODUTOS EM EMPRESAS DO SEGMENTO DE AÇOS PLANOS DO SETOR SIDERÚRGICO: UMA ABORDAGEM NO PROJETO DO PROCESSO}

Dissertação apresentada à Escola Politécnica da Universidade de São Paulo para obtenção do título de Mestre em Engenharia de Produção. 


\title{
ESTUDO EXPLORATÓRIO NO DESENVOLVIMENTO DE NOVOS PRODUTOS EM EMPRESAS DO SEGMENTO DE AÇOS PLANOS DO SETOR SIDERÚRGICO: UMA ABORDAGEM NO PROJETO DO PROCESSO
}

\begin{abstract}
Dissertação apresentada à Escola Politécnica da Universidade de São Paulo para obtenção do título de Mestre em Engenharia de Produção.
\end{abstract}

Área de concentração: Qualidade e Engenharia do Produto.

Orientador: Paulo A. Cauchick Miguel Professor Associado 
Este exemplar foi revisado e alterado em relação à versão original, sob responsabilidade única do autor e com a anuência de seu orientador.

São Paulo, de junho de 2008.

Assinatura do autor

Assinatura do orientador

\section{FICHA CATALOGRÁFICA}

Varandas Junior, Angelo

Estudo exploratório no desenvolvimento de novos produtos em empresas do segmento de aços planos do setor siderúrgico : uma abordagem no projeto do processo / A. Varandas Junior. -ed.rev. -- São Paulo, 2008.

$149 \mathrm{p}$.

Dissertação (Mestrado) - Escola Politécnica da Universidade de São Paulo. Departamento de Engenharia de Produção.

1.Desenvolvimento de produtos 2.Indústria siderúrgica 3.Aço 4.Projeto do processo I.Universidade de São Paulo. Escola Politécnica. Departamento de Engenharia de Produção II.t. 
À Danielle, minha esposa, minha amiga, meu grande amor. 


\section{AGRADECIMENTOS}

Agradeço inicialmente ao orientador deste trabalho, Prof. Dr. Paulo Augusto Cauchick Miguel, pela grande atenção dedicada durante esta trajetória.

A Profa. Dra. Marly Monteiro de Carvalho e ao Prof. Dr. Ricardo Manfredi Naveiro, pela grande contribuição dada ao trabalho durante o exame de qualificação.

Aos amigos da Pós Graduação, pela enorme ajuda, paciência, e amizade.

A Universidade de São Paulo, Escola Politécnica, pela oportunidade de cursar 0 Mestrado nesta respeitada instituição.

As empresas COSIPA e USIMINAS, por permitir e incentivar a realização desta jornada acadêmica.

À minha família, em especial a minha mãe, por me apoiar nas decisões tomadas durante a minha vida pessoal e profissional.

À Danielle, minha grande companheira, pelo carinho e compreensão nos bons e nos maus momentos.

A todos que de alguma maneira contribuíram para a realização deste trabalho de pesquisa, e não foram citados. 
"Para adquirir conhecimento é preciso estudar, mas para adquirir sabedoria, é preciso observar."

Marilyn vos Savant 


\section{RESUMO}

VARANDAS, A. Jr. (2008). Estudo exploratório no desenvolvimento de novos produtos em empresas do segmento de aços planos do setor siderúrgico: uma abordagem no projeto do processo. 2008. 149p. Dissertação (Mestrado) - Escola Politécnica, Universidade de São Paulo, São Paulo, 2008.

A demanda pela introdução de novos produtos tem sido intensificada no setor siderúrgico, justificando uma preocupação maior com a eficiência e a eficácia do Processo de Desenvolvimento de Produtos (PDP), cujo desempenho depende de vários fatores relevantes citados na literatura. No caso da indústria siderúrgica, um fator relevante é o projeto do processo, não somente pela característica de ser um processo contínuo mas também por, geralmente, envolver investimentos significativos na preparação da produção. Nesse contexto, o presente trabalho tem como objetivo realizar uma análise exploratória da fase de projeto do processo no desenvolvimento de novos produtos em duas unidades de análise do setor siderúrgico. Pretende-se, por meio da abordagem de estudo de caso, identificar práticas organizacionais, com base na literatura, focando na parte do desenvolvimento industrial e suas respectivas interfaces organizacionais, envolvendo as áreas de marketing, engenharia do produto e manufatura. Também é abordado a forma de integração dos times multidisciplinares, a tomada de decisão e os critérios utilizados para avaliação dos resultados do processo de desenvolvimento de produtos. O trabalho conclui que as empresas analisadas utilizam-se de práticas que estruturam o PDP e a integração interfuncional das áreas envolvidas é o que destaca-se como fator de sucesso na condução do desenvolvimento de novos produtos.

Palavras-chave: Processo de desenvolvimento de produtos. Projeto do processo. Setor siderúrgico. 


\section{ABSTRACT}

VARANDAS, A. Jr. (2008). Study research of the process project of new product development process in a Brazilian steel industry. 2008. 149p. M. Sc. Dissertation - Escola Politécnica, Universidade de São Paulo, São Paulo, 2008.

The demand for introducing new products has intensely increase in the metal industry. This justifies a growing concern with effectiveness of New Product Development (NPD) process, from which the performance depend on various relevant factors from the literature. In the case of the metal industry, one of the relevant factors is the manufacturing process design not only because is a continuous process but also because it involves significant investments to prepare production. In this context, this paper aims at performing a exploratory analysis of process design stage in two industrial units from metal industry. It intends to identify organizational practices e their respective interfaces, involving areas of marketing, product engineering and manufacturing. It also deals with the way multifunctional teams are integrated, decision making process, and criteria used to evaluate the results from NPD. The paper concludes that the two companies adopt organizational practices that create a framework for NPD and the integration of functional areas is one of the success factor for developing new products.

Key Words: Product development process. Process project. Steel industry. 


\section{LISTA DE FIGURAS}

Figura 1 - Etapas para elaboração do referencial teórico.

Figura 2 - Tópicos encontrados na varredura horizontal

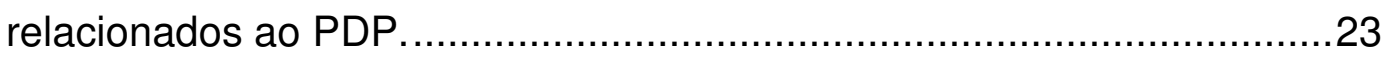

Figura 3 - Fases do desenvolvimento de novos produtos. ...................................26

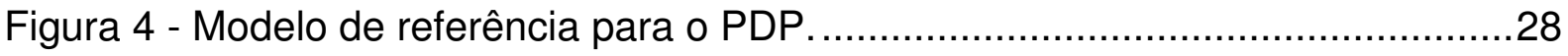

Figura 5 - Atualização do modelo de referência para o PDP. ..................................29

Figura 6 - Processo de revisão de fases no PDP................................................29

Figura 7 - Funil de desenvolvimento de novos produtos...........................................

Figura 8 - Tipos de projetos baseados na inovação no PDP. ..................................32

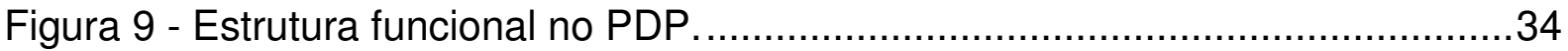

Figura 10 - Estrutura autônoma ou por projeto no PDP. ...........................................35

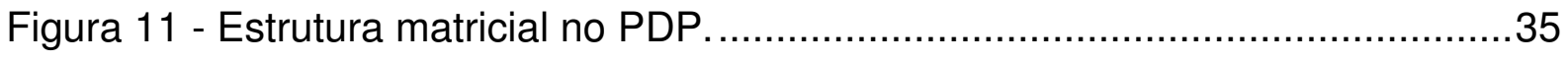

Figura 12 - Estrutura referencial para compreensão do PDP.................................45

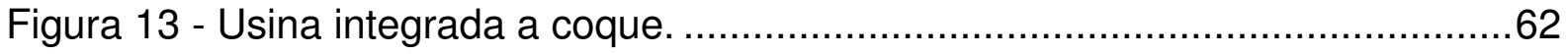

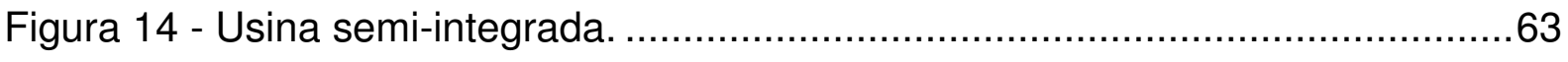

Figura 15 - Produtos planos distribuídos por características e

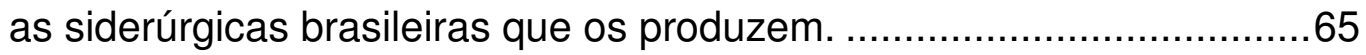

Figura 16 - Produtos longos distribuídos por características e as siderúrgicas brasileiras que os produzem. ......................................66

Figura 17 - Produtos trefilados distribuídos por características e as siderúrgicas brasileiras que os produzem. ....................................67

Figura 18 - Estrutura metodológica do trabalho. ................................................ 76

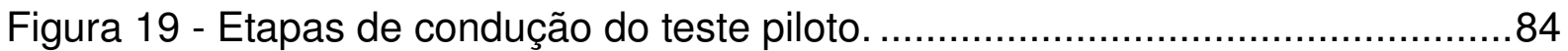

Figura 20 - Estrutura organizacional e times do PDP

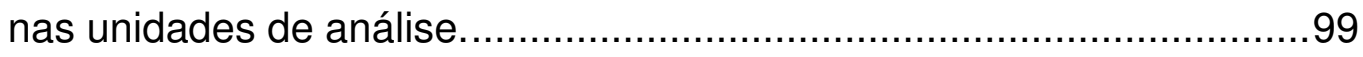

Figura 21 - Distribuição de projetos por área de negócios nas unidades de análise em 2006-2007........................................101

Figura 22 - Fluxograma do PDP nas unidades de análise. ....................................102

Figura 23 - Os deliverables de passagem de fase no PDP das unidades de análise. 


\section{LISTA DE TABELAS}

Tabela 1 - Abordagens do processo de desenvolvimento de novos produtos. .........25

Tabela 2 - Tipos de arranjos organizacionais para o PDP.....................................36

Tabela 3 - Principais indicadores de sucesso no PDP...........................................

Tabela 4 - Indicadores de desempenho utilizados por empresas no PDP................38

Tabela 5 - Indicadores utilizados por empresas para medir a

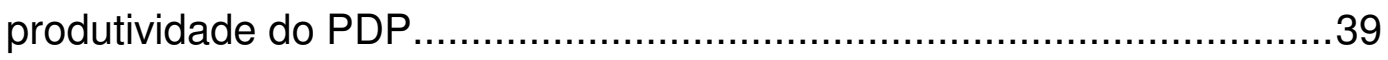

Tabela 6 - Atividades funcionais de integração interfuncional no PDP. ....................40

Tabela 7 - Principais abordagens metodológicas encontradas na

varredura vertical relacionados ao projeto do processo.

Tabela 8 - Variáveis encontradas na varredura vertical relacionadas

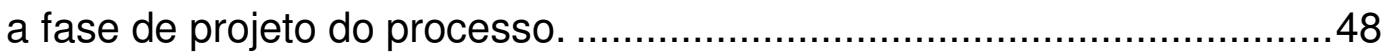

Tabela 9 - Produção siderúrgica brasileira por tipo de produto. .................................56

Tabela 10 - Produção de aço bruto por empresa no Brasil. ......................................57

Tabela 11 - Produção de laminados planos por empresa no Brasil. .........................59

Tabela 12 - Produção de aço bruto da América latina. ............................................68

Tabela 13 - Investimentos do setor siderúrgico por área de aplicação. .....................69

Tabela 14 - Síntese das principais características metodológicas do trabalho.

Tabela 15 - Síntese dos principais tipos de instrumentos de coleta e análise de dados utilizados no trabalho.

Tabela 16 - Principais documentos complementares utilizados na análise documental.

Tabela 17 - Aplicação dos instrumentos de coleta de dados nas unidades de análise.

Tabela 18 - Participação das unidades de análise no mercado interno de produtos laminados planos.

Tabela 19 - Síntese dos principais indicadores das unidades de análise selecionadas para pesquisa.

Tabela 20 - Principais áreas envolvidas no processo de fabricação de aços planos. 
Tabela 21 - Estrutura de funcionários envolvidos no PDP das unidades de análise.

Tabela 22 - Projetos de desenvolvimento de novos produtos das unidades de análise

Tabela 23 - Uma visão da organização do trabalho no PDP das unidades de análise.

Tabela 24 - As principais variáveis relacionadas ao PDP na visão das áreas envolvidas no desenvolvimento de novos produtos.

Tabela 25 - As principais variáveis relacionadas ao projeto do processo na visão das áreas envolvidas no PDP. 116

Tabela 26 - Análise das principais variáveis selecionadas na literatura com o projeto do processo das unidades de análise 


\section{LISTA DE ABREVIATURAS E DE SIGLAS}

ABNT Associação Brasileira de Normas Técnicas

AÇOMINAS Aços Minas Gerais

AISI

American Iron and Steel Institute

ANPEI

Associação Nacional de Pesquisa, Desenvolvimento e Engenharia das Empresas Inovadoras

API

American Petroleum Institute

ASTM

American Society of Testing and Materials

AV/EV

Análise de Valor ou Engenharia de Valor

COSIPA

Companhia Siderúrgica Paulista

CSN

Companhia Siderúrgica Nacional

CST

Companhia Siderúrgica de Tubarão

DFA

Design for Assembly - Projeto para Montagem

DFM

Design for Manufacturing - Projeto para Manufatura

DIP

Desenvolvimento Integrado de Produtos

FMEA

Failure Mode and Effect Analysis - Análise dos Modos de Falha e seus Efeitos

FTA

Fault Tree Analysis - Análise da Árvore de Falhas

GDP

Gestão do Desenvolvimento de Produtos

GEI2

Grupo de Engenharia Integrada e de Integração

IBGE

Instituto Brasileiro de Geografia e Estatística

IBS

Instituto Brasileiro de Siderurgia

INPI

Instituto Nacional de Propriedade Industrial

ISO

International Organization for Standardization

ISO TS

International

Organization for Standardization

Technical

Specification

JIS

Japanese Industrial Standard

MIT

Massachussetts Institute of Technology

NPD

New Product Development

NUMA

Núcleo de Manufatura Avançada 
PDCA Plan, Do, Check, Act - Planejamento, Execução, Verificação e Ação

P\&D Pesquisa e Desenvolvimento

PDBP Product Development Business Process

PDMA Product Development \& Management Association

PDP Processo de Desenvolvimento de Produtos

PES Porsche Engineering Services Inc.

PINTEC Pesquisa de Inovação Tecnológica

PVP Plano de Venda e Produção

QFD Quality Function Deployment

RAE Roteiro de Acompanhamento de Experiência

ROI Return On Investment

SAE Society of Automotive Engineers

SIDERBRAS Siderurgia Brasileira S.A

TIR Taxa Interna de Retorno

ULSAC Ultra Light Steel Auto Closures

ULSAB Ultra Light Steel Auto Body

USIBA Usina Siderúrgica da Bahia

USIMINAS Usinas Siderúrgicas de Minas Gerais 


\section{SUMÁRIO}

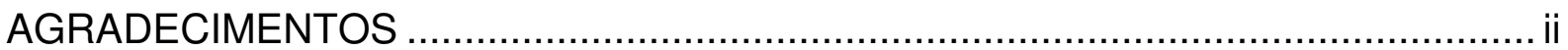

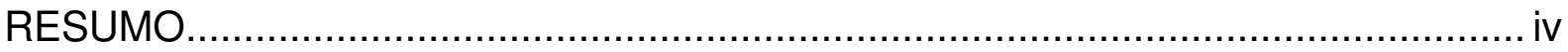

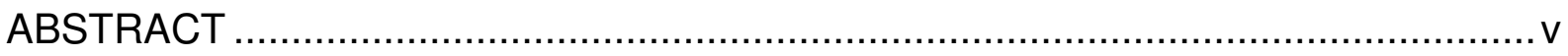

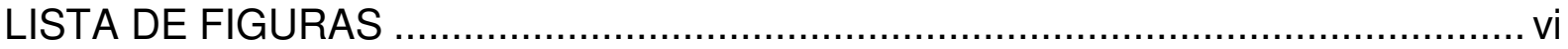

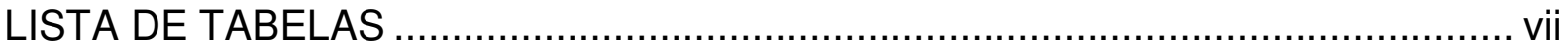

LISTA DE ABREVIATURAS E DE SIGLAS ...................................................... ix

1 INTRODUÇÃO

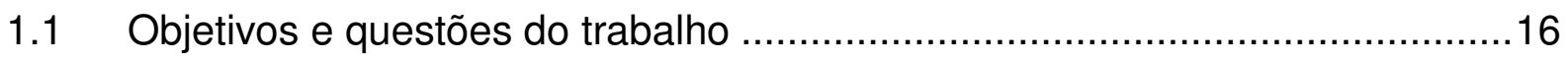

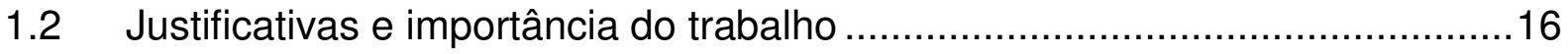

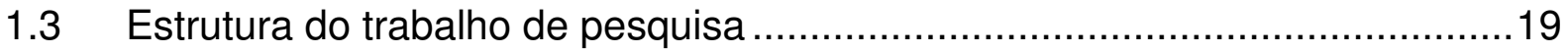

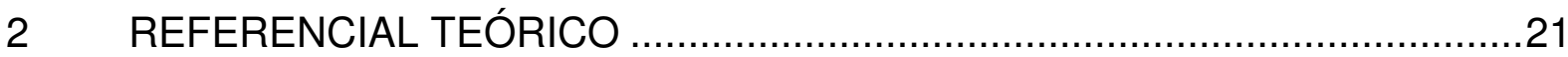

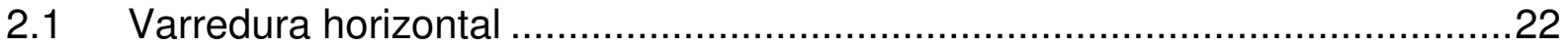

2.1.1 Processo de Desenvolvimento de Produtos (PDP) .....................................24

2.1.2 A importância da integração interfuncional no PDP .......................................39

2.1.3 Utilização de métodos e técnicas de suporte ao PDP …..............................42

2.1.4 Estrutura referencial para compreensão do PDP …....................................45

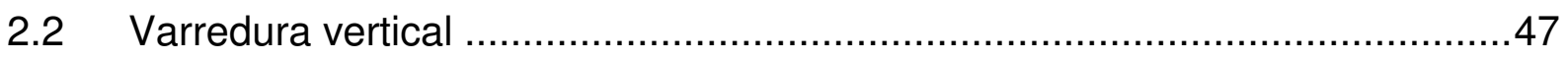

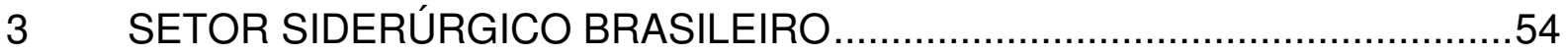

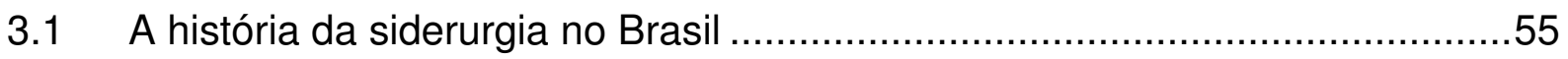

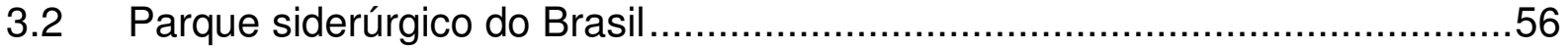

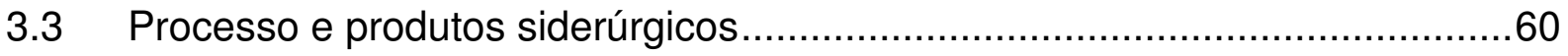

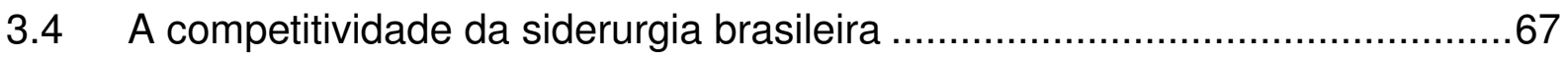

3.5 Inovação tecnológica da siderurgia brasileira ............................................71

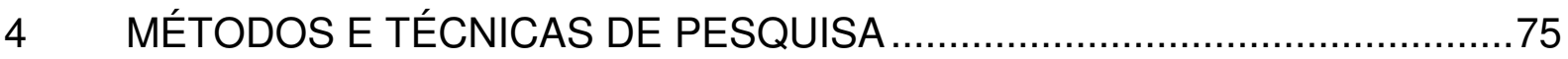

4.1 Fases para realização do trabalho de pesquisa ..........................................76

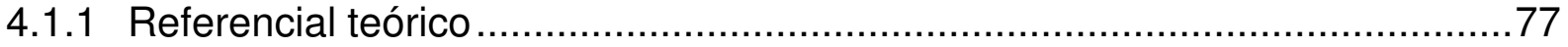

4.1.2 Investigação empírica: planejar o caso ..................................................77 
4.1.2.1 Investigação empírica: métodos e técnicas de pesquisa

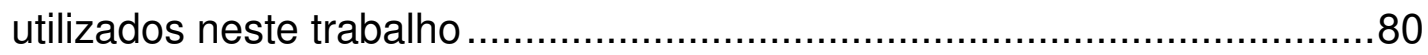

4.1.2.2 Investigação empírica: conduzir teste piloto ............................................ 83

4.1.3 Comparação das unidades de análise: estudo

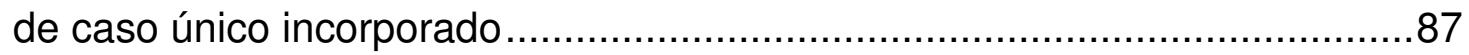

4.1.3.1 Comparação das unidades de análise: coletar os dados ...........................88

4.1.3.2 Comparação das unidades de análise: analisar os dados .........................89

5 ESTUDO DE CASO - DESCRIÇÃO E RESULTADOS …...........................90

5.1 Seleção e caracterização das unidades de análise ......................................90

5.2 Descrição sobre a estrutura do PDP das unidades de análise .......................96

5.3 Análise da fase de projeto do processo no PDP das unidades de análise

6 CONCLUSÕES E SUGESTÕES PARA TRABALHOS FUTUROS ..............122

6.1 Sugestões para trabalhos futuros ........................................................127

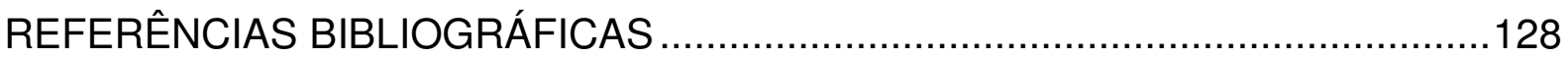

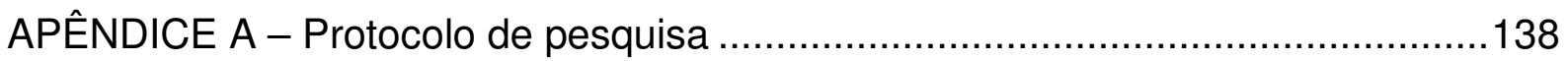

APÊNDICE B - Questionário para compreensão do Processo de

Desenvolvimento de Produtos (PDP)

APÊNDICE C - Tabela para avaliação das principais variáveis

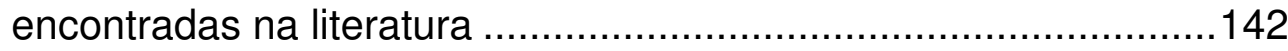

APÊNDICE D - Roteiro de entrevista não-estruturada .......................................145

APÊNDICE E - Questionário para análise da fase de projeto do processo no PDP 146

ANEXO A - Etapas do processo de fabricação de aços planos

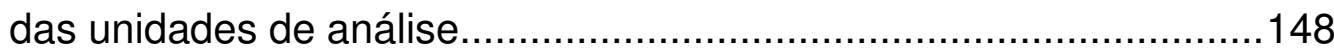

ANEXO B - Roteiro de Acompanhamento de Experiência (RAE) ...........................149 


\section{INTRODUÇÃO}

O processo de desenvolvimento de produto (PDP) é essencial na construção e sustentação da vantagem competitiva, considerando uma das mais importantes atividades nas empresas no fortalecimento da posição no mercado. Este processo consiste de um conjunto de atividades que são executadas na definição de novos produtos, incluindo o levantamento de informações do mercado até a homologação final do produto, do processo e a transmissão das informações sobre o projeto e o produto para todas as áreas funcionais da empresa, considerando que alternativas são identificadas e avaliadas com critérios definidos (ROZENFELD et al., 2006). Sua função é integrar todos esses critérios e otimizá-los, considerando as restrições (CLARK; FUJIMOTO, 1991).

De um modo geral, a demanda pela introdução de novos produtos tem aumentado intensamente, justificando uma preocupação maior com a eficiência e a eficácia do PDP (ROZENFELD et al., 2006). Esse desempenho depende da gestão do PDP, que deve ir além da busca pelo menor custo, sendo também condições desejáveis para a competitividade a colocação do produto no mercado o mais rapidamente possível, a manufaturabilidade do produto e a criação e 0 fortalecimento, a cada projeto, das capacitações requeridas para o PDP no futuro (PORTER, 1989; MUNDIM et al., 2002).

Acompanhando essas mudanças nos produtos, o PDP vem sofrendo uma evolução, que atualmente está dividida em três eras (ROZENFELD et al., 2006): desenvolvimento seqüencial de produtos, que tinha como foco principal à divisão de tarefas, especialização e ênfase nas áreas funcionais; desenvolvimento integrado de produtos, que se caracteriza por englobar as abordagens de engenharia simultânea, do funil de desenvolvimento de Clark e Wheelwright (1992) e do stage-gates de Cooper (1993); e novas abordagens para desenvolvimento integrado de produtos, que engloba o desenvolvimento lean, o design for six sigma e os modelos de maturidade (CUNHA, 2004).

Seguindo essa evolução, os trabalhos de Clark e Fujimoto (1991), Clark e Wheelwright (1992; 1993), Clausing (1994), Pugh (1996), Prasad (1997) e Rozenfeld et al. (2000) destacam que o PDP é constituído por quatro macros tópicos interrelacionados: estratégico, que compreende a gestão do portfólio, desempenho do processo, condução de alianças e parcerias, condução de relações interfuncionais e 
interdepartamentais; organizacional, que engloba a gestão da estrutura organizacional, liderança e capacitação dos funcionários; atividades e informações, que se preocupam com as etapas operacionais e com a normalização e controle das informações geradas; e recursos, que são as técnicas, métodos e ferramentas de apoio.

Além destes quatro macros tópicos inter-relacionados, a visão atual do PDP é de um processo de negócio que foca o cliente final, integrando as pessoas e áreas funcionais em uma busca de simultaneidade na realização das tarefas (CARTER; BAKER, 1992; CLAUSING, 1994; ROZENFELD, 1996; CHENG, 2000; AMARAL, 2002; TONIOLI, 2003). A partir deste conceito de processo, diversos autores dividem o PDP em fases distintas visando sua melhor operacionalização, como Clark e Wheelwright (1992) que dividem o PDP em quatro fases: desenvolvimento do conceito, planejamento do produto, engenharia do produto/processo e produção piloto/aumento da produção, intercalados por uma revisão de fases, que consiste em um ponto de decisão gerencial que avalia a possibilidade de continuidade do projeto e os riscos envolvidos nesta decisão (COOPER, 1993).

As duas fases iniciais do PDP incluem informações sobre as oportunidades de mercado, as possibilidades técnicas e o levantamento dos requisitos de produção. $\mathrm{Na}$ fase de engenharia do produto/processo ocorre o desenvolvimento do projeto, a construção de protótipos e a criação de ferramentas para produção. A fase de produção piloto compreende a construção e teste dos meios de produção, e a última fase do PDP compreende o aumento do volume de produção, que envolve o refinamento dos parâmetros de processo e dos custos e melhoria da qualidade do produto e do processo de fabricação.

Analisando cada fase do PDP, verifica-se que é na fase de projeto do processo que os projetos detalhados do produto são traduzidos em planos de fabricação. As informações dessa fase incluem definições e dados necessários para fabricação do produto. Nesta fase ocorre com mais freqüência as alterações de projeto, o que implicam na perda de trabalhos previamente realizados (BARKAN, 1992). De acordo com o autor previamente citado, as modificações de engenharia são consideradas problemas de primeira ordem no PDP, que podem ser utilizadas como item de controle para medir a eficácia da gestão no desenvolvimento de novos produtos. Afinal, os retrabalhos na fase de projeto do processo geram impactos diretos sobre 0 
custo, tempo de desenvolvimento, e impactos indiretos sobre a qualidade dos produtos (ROZENFELD, 1996).

De forma ampla, as empresas têm buscado vantagem competitiva no desenvolvimento de novos produtos e, conseqüentemente, estão cada vez mais atentas as necessidades do cliente, ao tempo de chegada do produto ao mercado e a redução dos custos de retrabalhos no processo (TATIKONDA; MONTOYA-WEISS, 2001). Esta preocupação com custos de retrabalho pelas empresas conduz a utilização de estruturas de PDP divididas em fases e também pela definição das responsabilidades das áreas envolvidas neste processo (CLARK; FUJIMOTO, 1991).

A preocupação com custos de retrabalhos é uma realidade que vem ocorrendo também em empresas do setor siderúrgico, foco do presente estudo, em função da introdução de novos produtos gerada pelo mercado, e da importância do projeto de processo para essas empresas. A estratégia de crescimento da siderurgia brasileira baseia-se no enobrecimento de produtos e a renovação tecnológica em mudanças técnicas incrementais de processos (PAULA, 2002). Assim, a estruturação do PDP é também necessária a estas empresas, devido a sua natural complexidade, principalmente de caráter organizacional, conforme a classificação de Clark e Fujimoto (1991).

As empresas deste setor apresentam hoje uma complicada interface organizacional $^{1}$, que compreende o relacionamento entre diferentes pessoas, recursos, conhecimento e funções da empresa, tais como marketing, engenharia do produto e manufatura. Além disso, para se desenvolver um produto novo, necessitase da interação destas interfaces da organização, que são gerenciadas por diferentes pessoas, com visões distintas da importância do PDP como um negócio da empresa, causando dificuldades na sua gestão (COSTA SILVA, 2000). Identificase ainda que na fase de projeto do processo exista a necessidade de uma maior estruturação da gestão e utilização de métodos e técnicas de suporte ao PDP, devido à intensificação de problemas de interface organizacional e aumento de gastos de projeto nesta fase (SANTOS; FORCELLINI, 2003). O conceito de interface organizacional utilizado neste trabalho refere-se ao gerenciamento de diversas

\footnotetext{
${ }^{1}$ Exemplo de complicada interface organizacional no PDP do setor siderúrgico: a manufatura é composta de equipamentos complexos (Aciaria, Alto forno e Laminação) que precisam atingir metas de produção, enquanto a engenharia do produto tem que desenvolver um novo produto e necessita fazer um teste piloto na linha, reduzindo o ritmo de produção. Já a área de marketing foca em atender as necessidades dos clientes e prefere desenvolver produtos com market share maior.
} 
funções da empresa envolvidas no PDP que, conforme citado por Altamirano (1999), Maltz et al. (2001), Haque et al. (2003), Sousa Mendes e Toledo (2003) e Krishnan e Loch (2005) tem dificuldades de integração e objetivos diferentes quanto ao PDP.

Partindo do princípio que existe uma demanda por novos produtos no setor siderúrgico e necessidade de se gerenciar a complexidade organizacional para se ter sucesso no PDP, o presente trabalho pretende fazer uma análise comparativa com a literatura das práticas organizacionais no PDP de duas unidades de análise do segmento de aços planos do setor siderúrgico brasileiro, que possuem a gestão estruturada do PDP, por meio de um estudo de caso de natureza exploratória.

\subsection{Objetivos e questões do trabalho}

Dentro da abordagem de Desenvolvimento Integrado dos Produtos (DIP), este trabalho se concentra em um objetivo geral e dois específicos. O geral consiste em obter uma caracterização do PDP, e os específicos de verificar, com base na literatura, como a fase de projeto do processo no PDP está estruturada, e qual a importância de algumas variáveis (identificadas no Capítulo 2 de referencial teórico) nesta fase. $O$ trabalho pretende também identificar como são conduzidos os problemas de interface organizacional na fase de projeto do processo.

A fim de se atingir os objetivos específicos apontados, o presente trabalho pretende contribuir com respostas as seguintes questões de pesquisa:

- Como está estruturada a fase de projeto do processo em duas unidades de análise de empresa do segmento de aços planos do setor siderúrgico brasileiro?

- Qual a relação das variáveis consideradas importantes ao PDP com a fase de projeto do processo em duas unidades de análise de empresa do segmento de aços planos do setor siderúrgico brasileiro?

\subsection{Justificativas e importância do trabalho}

A necessidade de administrar com maior eficiência, aliada a problemática da adequação da geração de novos produtos a um mercado sempre mais exigente, 
com uma gama crescente de opções para sua operação requer das empresas uma maior capacitação organizacional no domínio do PDP (MUNDIM et al., 2002).

Partindo da necessidade de uma melhor gestão do PDP, o levantamento bibliográfico realizado identificou três tópicos considerados importantes neste tema: a visão do PDP como um processo do negócio; a influência da complexidade do produto e do processo; e a fase de projeto do processo. De acordo com Santos e Forcellini (2003) é importante realizar mais trabalhos na fase de projeto do processo, pois poucos estudos têm sido desenvolvidos sobre este tema e os autores salientam que nesta fase do PDP há uma intensificação de problemas de interface organizacional e aumento de custos do projeto.

Adicionalmente a estes tópicos destacados na literatura, vários autores (ALTAMIRANO, 1999; MALTZ et al., 2001; ABDOMEROVIC; BLAKEMORE, 2002; SOUSA MENDES; TOLEDO, 2003) destacam que apesar de estruturado o PDP ainda existe muitas dificuldades de integração das diferentes funções organizacionais (marketing, engenharia do produto e manufatura) envolvidas no PDP. Devido à relevância desta integração interfuncional no PDP, percebe-se então que existem muitos fatores importantes no PDP que merecem ser analisados em profundidade principalmente na fase de projeto do processo, tais como: a utilização de diferentes arranjos organizacionais, adoção de times multidisciplinares e a definição dos respectivos papéis e divisão do trabalho.

Após ter sido observado a relevância do tema "fase de projeto do processo" na literatura e no PDP, identificou-se como unidade de análise para este trabalho o setor siderúrgico devido às especificidades operacionais e organizacionais, que são descritas a seguir.

O requisito de qualidade aplicável aos produtos siderúrgicos tem aumentado, não apenas em rigor, como em complexidade (MARCUS; KIRSIS, 2004a). A indústria siderúrgica fornece bens intermediários para a maior parte dos setores econômicos, e vem experimentando forte concorrência de materiais alternativos, como plásticos e alumínio. Porém, o aço ainda é a principal fonte de material básico da indústria, especialmente aquela ligada a bens de consumo duráveis e a bens de capital (OLIVEIRA, 2003).

Dados do IBS (2007) destacam a importância dos indicadores econômico-sociais do setor siderúrgico para o país e do cenário de competição neste setor, seja com materiais alternativos e/ou entre as próprias empresas. É natural que grande ênfase 
seja dedicada a medidas destinadas a garantir o atendimento sistemático das características de qualidade requeridas pelo mercado e que visam o aumento da produtividade e da eficiência da empresa.

Destaca-se que o sucesso do setor siderúrgico depende extremamente do desempenho dos processos operacionais, diferenciando-se das demais empresas de extração e obtenção de metais, em que o valor intrínseco do metal é mais determinante que o processo de fabricação (MOURÃO, 2007). Além disso, a siderurgia, devido ao seu porte e características operacionais, envolve de maneira complexa diferentes unidades organizacionais, numerosas interfaces e problemas potenciais de responsabilidades que fazem parte de todos os processos da empresa. Muitos esforços têm sido dirigidos para organizar efetivamente a fase de projeto de processo, buscando solucionar esses problemas no PDP (CLARK; FUJIMOTO, 1990).

Assim, diferentes técnicas de controle e modelos de gestão de operações, vêm sendo desenvolvidos e empregados em empresas siderúrgicas brasileiras com diferentes graus de sucesso (COSTA SILVA, 2000). Esses esforços destinados à melhoria da qualidade e produtividade devem partir da visão de que uma organização como uma empresa siderúrgica, é, na verdade, um sistema complexo.

Considerando a complexidade organizacional do setor siderúrgico e o aumento da necessidade por novos produtos, nestas empresas, devido principalmente ao aumento de concorrência de materiais alternativos e exigências dos clientes por qualidade e variedade de produtos. As siderúrgicas brasileiras desenvolvem processos e produtos com certificação de qualidade, dentro de um sistema de gestão como, por exemplo, o sistema com base na certificação de qualidade para o setor automotivo ISO TS 16949 (2002), que tem como requisito a estruturação do PDP.

É importante destacar que o interesse pela realização do trabalho no setor siderúrgico está ainda relacionado ao fato do pesquisador atuar em uma empresa deste segmento. Além disso, o trabalho se justifica para o autor que por meio do curso de mestrado busca o desenvolvimento pessoal e profissional.

Por fim, em função de sua relevância anteriormente destacada, se justifica a escolha do tema "fase de projeto do processo" e do setor siderúrgico como recorte de análise para este trabalho. Após contextualização do tema, elaboração dos 
objetivos e questão de pesquisa e justificado a importância da fase de projeto do processo no PDP, a próxima seção apresenta a estrutura geral do trabalho.

\subsection{Estrutura do trabalho de pesquisa}

O presente trabalho de pesquisa sobre a fase de projeto do processo no PDP é composto por 6 capítulos, incluindo este introdutório. O segundo capítulo detalha a elaboração do referencial teórico; o terceiro capítulo faz uma caracterização do setor siderúrgico brasileiro; o quarto capítulo demonstra os métodos e técnicas de pesquisa adotados; o quinto capítulo discute os resultados do estudo de caso; e por último, o sexto capítulo descreve as conclusões e sugestões para trabalhos futuros.

O Capítulo 2, de "Referencial teórico", apresenta a fundamentação teórica ligada ao tema de pesquisa, e constitui o alicerce conceitual que sustenta todo o trabalho. Nesta revisão bibliográfica ${ }^{2}$ é realizada uma busca ampla sobre o PDP, abordando os métodos e técnicas de suporte ao PDP, a integração interfuncional, as principais formas de arranjos organizacionais e variáveis que influenciam no PDP, e em seguida introduzida a visão de vários autores sobre as principais variáveis relacionadas à fase de projeto do processo no desenvolvimento de novos produtos.

Estas variáveis encontradas na literatura, sobre o projeto do processo, servem de base para elaboração dos questionários e entrevistas, utilizados na condução da parte empírica do trabalho.

O Capítulo 3, "Setor siderúrgico brasileiro", apresenta uma caracterização do setor siderúrgico e detalha os principais processos de fabricação de aço, os produtos comercializados no mercado interno, a competitividade entre as empresas e a dinâmica tecnológica deste setor, dando ênfase ao processo de desenvolvimento de novos produtos no segmento de aços planos comuns.

O Capítulo 4, "Métodos e técnicas de pesquisa", apresenta as macro fases de condução do trabalho de pesquisa e a preparação da parte empírica da pesquisa, no qual são discutidos e justificados os aspectos metodológicos adotados no trabalho,

\footnotetext{
${ }^{2}$ Na revisão bibliográfica é utilizado o conceito de Hart (2001), de procurar na literatura itens relevantes, por meio da utilização da estratégia "Trawling and Mining for Information", para planejamento e preparação da pesquisa. Inicialmente, é realizada uma busca bibliográfica ampla sobre determinado tema (varredura horizontal) e depois uma busca mais focada sobre determinado assunto de interesse (varredura vertical), selecionando itens relevantes e realizando uma análise crítica entre os itens encontrados.
} 
os instrumentos de coleta e análise de dados, e os critérios para seleção das unidades de análise.

O Capítulo 5, "Estudo de caso", apresenta os resultados empíricos e busca demonstrar uma análise dos dados coletados, através da aplicação do protocolo de pesquisa nas duas unidades de análise. Nesse sentido, o capítulo inicialmente apresenta uma caracterização das duas unidades de análise selecionadas, pertencentes a uma corporação do setor siderúrgico. Em seguida, é demonstrado como está estruturado o PDP nas duas empresas e conseqüentemente é realizada uma análise mais específica da fase de projeto de processo.

O Capítulo 6, "Conclusões e sugestões para trabalhos futuros", sintetiza as principais conclusões do trabalho e algumas considerações finais. O trabalho finaliza com a apresentação das principais dificuldades encontradas durante a pesquisa e propõe temas a serem abordados em trabalhos futuros. 


\section{REFERENCIAL TEÓRICO}

Na busca por uma compreensão do Processo de Desenvolvimento de Produtos ${ }^{3}$, aborda-se neste capítulo conhecimentos multidisciplinares, que mais se aproximam deste tema. Assim, a literatura que serve de base para este trabalho associa conhecimentos de diferentes áreas sobre o PDP. O referencial teórico apresenta uma visão geral dos principais tópicos relacionados ao PDP, abordando as diversas formas de estruturação deste processo. Por fim, consegue-se identificar variáveis relacionadas à fase de projeto do processo, que são citadas por diversos autores na literatura e são destacadas mais a frente.

A elaboração do referencial teórico do trabalho é feita conforme mostra a figura 1, inicia-se com uma busca ampla sobre o PDP, varredura horizontal ${ }^{4}$, que contempla os seguintes tópicos: processo de desenvolvimento de produtos; integração interfuncional no PDP; métodos e técnicas de suporte ao PDP; e a estrutura referencial de Clark e Wheelwright (1992) para compreensão do PDP. Após esta etapa, é realizada uma busca mais direcionada, varredura vertical ${ }^{5}$, afunilando o conceito de PDP para fase do projeto de processo, e com essas informações identifica-se os conceitos teóricos e as questões de pesquisa.

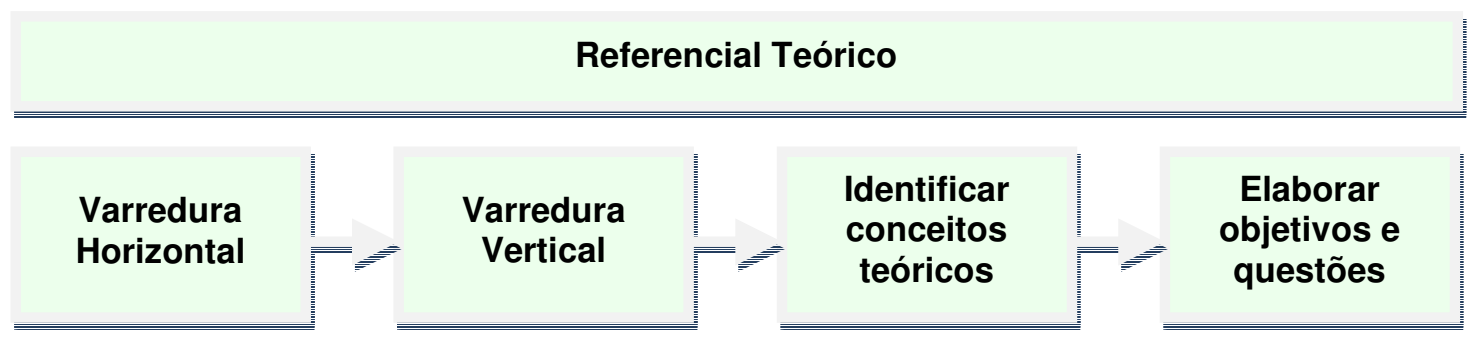

Figura 1 - Etapas para elaboração do referencial teórico.

Fonte: Elaborado pelo autor.

\footnotetext{
${ }^{3}$ O presente trabalho está inserido na abordagem do Desenvolvimento Integrado de Produtos, que tem uma visão sistêmica do PDP, tendo assim uma preocupação com a utilização de métodos e técnicas de suporte ao PDP, com a integração entre as áreas envolvidas no PDP e com as questões estratégicas e interfaces organizacionais da empresa (PRASAD, 1997).

${ }^{4}$ Inicialmente o trabalho partiu para literatura em busca de alguma lacuna sobre o PDP, que tivesse importância de ser pesquisada, logo foram abordados diversos assuntos relacionados a este tema de maneira a adquirir mais conhecimento e dar subsídios à escolha do foco da pesquisa.

${ }^{5}$ Após ter detectado os pontos relevantes ao tema PDP, o presente trabalho identificou que o foco do trabalho seria a fase de projeto do processo, e conseqüentemente teve o direcionamento da busca bibliográfica para este tema e suas respectivas variáveis.
} 


\subsection{Varredura horizontal}

O levantamento bibliográfico iniciou com uma varredura horizontal na literatura, abordando o PDP em busca de lacunas potenciais que poderiam ser investigadas. Esta busca inicial concentrou-se em bibliotecas e bases de dados, através de consultas em sites, artigos, dissertações e teses. Com a leitura do material inicialmente encontrado, foi-se delineando o contorno do tema de pesquisa e caracterizando-se suas abordagens. As seguintes fontes foram pesquisadas:

- Artigos: foram utilizados os sites do portal CAPES, PROQUEST e SIBI. Em relação ao tópico PDP foram pesquisados os quatro macros tópicos interrelacionados que compõe esse processo (estratégico; organizacional; atividades e informações; e recursos);

- Sites direcionados ao PDP: Product Development \& Management Association $(\mathrm{PDMA})^{6}$, que é uma associação internacional que congregam estudiosos e profissionais sobre o gerenciamento do PDP e tem como diferencial o fato de ser bastante multidisciplinar contando com profissionais da área de administração, marketing, engenharia e outras; Center for Innovation in Product Development (MIT) ${ }^{7}$; Núcleo de Manufatura Avançada (NUMA), que traz vários grupos de pesquisa, entre eles o Grupo de Engenharia Integrada e de Integração $(\mathrm{GEI} 2)^{8}$, também tem uma parte do site que disponibiliza vários conceitos e descrição de ferramentas utilizadas no PDP; por último o portal de compartilhamento de conhecimentos sobre Gestão do Desenvolvimento de Produtos (GDP) ${ }^{9}$.

Analisando as informações encontradas na revisão horizontal da literatura, percebeu-se que três tópicos importantes se destacam no PDP, conforme descrito a seguir e ilustrado na figura 2:

- As empresas têm como principal vertente à visão do PDP como um processo de negócio, que foca o cliente final, integrando as diferentes pessoas e áreas funcionais envolvidas e buscando uma simultaneidade na realização das

\footnotetext{
${ }^{6}$ www.pdma.org - Um ponto importante é que este site edita a revista The Journal of Product Innovation Management, que é um dos periódicos mais importantes em PDP e por manter uma característica multidisciplinar, trazendo inclusive resumo de artigos sobre o PDP de outras revistas.

${ }^{7}$ http://me.mit.edu - Centro de pesquisas do Massachussetts Institute of Technology, que desenvolve pesquisas avançadas sobre o PDP.

${ }^{8}$ www.numa.org.br - Este grupo trata principalmente de gestão de projetos; gestão do PDP e ciclo de vida de produtos; modelagem de processos; e aplicação de sistemas de informação.
} 
tarefas (CARTER; BAKER, 1992; CLAUSING, 1994; ROZENFELD, 1996; CHENG, 2000; AMARAL, 2002; TONIOLI, 2003);

- O PDP pode ser classificado sob vários aspectos, dependendo das características do produto a ser desenvolvido. Para Clark e Fujimoto (1991), duas são consideradas mais importantes e podem dificultar a conquista das metas: a complexidade do produto e a complexidade organizacional;

- Identifica-se ainda que na fase de projeto do processo ${ }^{10}$ existe a necessidade de uma maior estruturação da gestão e utilização de métodos e técnicas de suporte ao PDP, devido à intensificação de problemas de interface organizacional e aumento de custos do projeto nesta fase (BARKAN, 1992; SANTOS; FORCELLINI, 2003).

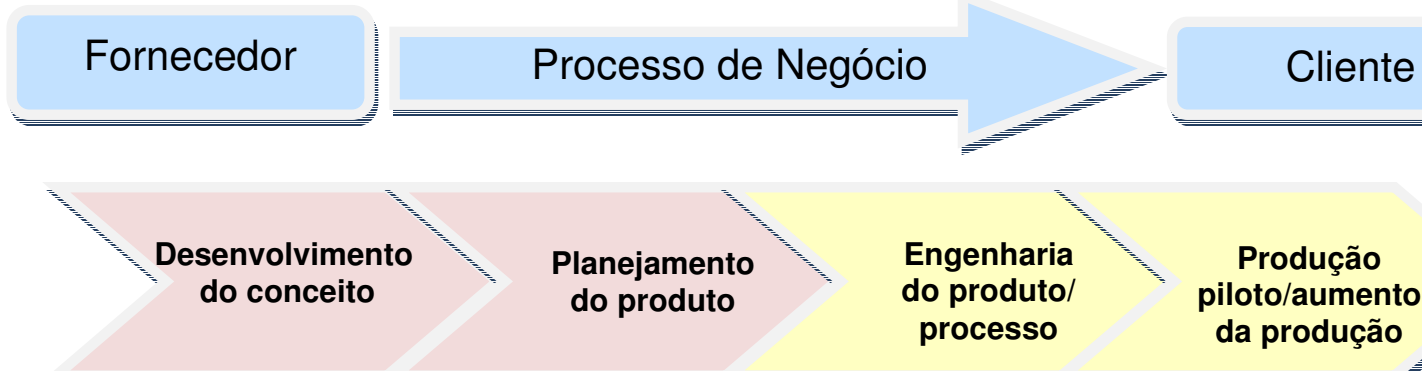

Atividades, Organização, Informação e Recursos

Complexidade do produto e organizacional

Figura 2 - Tópicos encontrados na varredura horizontal relacionados ao PDP.

Fonte: Elaborado pelo autor com base em Rozenfeld (1996).

Após ter identificado tópicos importantes na literatura sobre o PDP, na próxima seção são descritos os principais tópicos abordados na varredura horizontal, que resultaram neste contexto que caracteriza a importância da fase de projeto do processo no PDP e da complexidade organizacional em alguns setores industriais.

\footnotetext{
${ }^{9}$ www.pdp.org.br - Traz o modelo de referência do PDP proposto por Rozenfeld et al. (2006).

${ }^{10}$ A definição de fase de projeto do processo utilizada neste trabalho considera a fase de engenharia do produto/processo e parte da produção piloto/aumento de produção conforme divisão de Clark e Wheelwright (1992). Já no modelo referencial para PDP proposto por Rozenfeld et al. (2006), a nomenclatura é diferente, incluem-se as fases de projeto detalhado e preparação da produção.
} 


\subsubsection{Processo de Desenvolvimento de Produtos (PDP)}

Existem várias definições para o PDP, que são praticamente convergentes quanto à importância deste processo, e complementares quanto ao detalhamento da quantidade de fases e a relação entre as variáveis do PDP. Basicamente todas as definições iniciam com as necessidades do mercado, têm-se algumas fases intermediárias, no qual há necessidade de integração de várias áreas organizacionais e finaliza-se o processo com um produto final lançado no mercado. Seguem algumas definições encontradas na literatura:

É o processo a partir do qual informações sobre o mercado são transformadas nas informações e bens necessários para a produção de um produto com fins comerciais (CLARK; FUJIMOTO, 1991).

É a atividade sistemática necessária desde a identificação do mercado e necessidades dos usuários até a venda de produtos capazes de satisfazer estas necessidades - uma atividade que engloba produto, processos, pessoas e organização (PUGH, 1991).

É o processo de negócio que compreende desde a idéia inicial e o levantamento de informações do mercado até a homologação final do produto, do processo e a transmissão das informações sobre o projeto e o produto para todas as áreas funcionais da empresa (ROZENFELD et al., 2000).

Há diferentes abordagens propostas para a análise do PDP, sendo que estas abordagens têm origens em áreas específicas do conhecimento, valorizando diferentes aspectos deste processo. Algumas das mais importantes são mostradas na tabela 1. 
Tabela 1 - Abordagens do processo de desenvolvimento de novos produtos.

\begin{tabular}{l|l}
\hline \multicolumn{1}{c|}{ AUTOR } & \multicolumn{1}{c}{ ABORDAGEM } \\
\hline \hline Clark e Fujimoto (1991), & $\begin{array}{l}\text { Esta abordagem desenvolveu projetos relacionados à manufatura } \\
\text { enxuta e a gestão do PDP, no qual os autores dividem o PDP em } \\
\text { três etapas maiores: estratégia de desenvolvimento; gerenciamento } \\
\text { do projeto específico; e aprendizagem. }\end{array}$ \\
\hline Pugh (1991; 1996) & $\begin{array}{l}\text { Esta abordagem possui preocupação com a busca de uma visão } \\
\text { total da atividade de projeto, ou seja, que superasse as visões } \\
\text { parciais presentes em cada setor tecnológico específico. Para } \\
\text { atingir este objetivo o autor dedicou uma grande ênfase à } \\
\text { educação e desenvolveu um modelo, que ficou muito conhecido } \\
\text { como Total Design. }\end{array}$ \\
\hline Clausing (1994) & $\begin{array}{l}\text { Esta abordagem criou uma visão denominada Total Quality } \\
\text { Development. Em que há um enfoque para as técnicas Quality }\end{array}$ \\
Function Deployment, método Taguchi e matriz de Pugh e para os \\
conceitos sobre gerenciamento dos times do PDP, inclusive \\
demonstra a integração entre os métodos e divide o PDP nas fases \\
de: conceito; design; e preparação.
\end{tabular}

Fonte: Elaborado pelo autor com base no Núcleo de Manufatura Avançada (2006) ${ }^{11}$.

O Processo de Desenvolvimento de Produtos, segundo Florenzano (1999), encontra-se na interface entre a empresa e o mercado tendo a responsabilidade de desenvolver um novo produto que atenda às expectativas do cliente, em termos de: manufaturabilidade, qualidade, velocidade e custo de projeto. Sendo que, atualmente, a demanda pela introdução de novos produtos tem aumentado intensamente, justificando uma preocupação maior com a eficiência e a eficácia do PDP (ROZENFELD et al., 2006).

Acompanhando essas mudanças nos produtos, o PDP vem sofrendo uma evolução nos procedimentos de sua execução (CUNHA, 2004), e os estudos sobre este tema consideram o PDP como um processo de negócio e abordam os quatro

\footnotetext{
${ }^{11}$ UNIVERSIDADE DE SÃO PAULO. Núcleo de Manufatura Avançada (NUMA). Grupo de Engenharia Integrada e de Integração. São Carlos. EESC, 2006. Disponível em: www.numa.org.br. Acesso em: 9 Out. 2006.
} 
macros tópicos inter-relacionados ao assunto (CHENG, 2000; AMARAL, 2002; TONIOLI, 2003): estratégico, organizacional, atividades e informações, e recursos.

A partir desta visão de processo, as empresas estão cada vez mais atentas as necessidades do cliente, ao tempo de chegada do produto ao mercado e a redução dos custos de retrabalhos no processo (TATIKONDA; MONTOYA-WEISS, 2001). Esta preocupação com custos de retrabalho por parte das empresas conduz a utilização de estruturas de PDP divididas em fases e também pela definição das responsabilidades das áreas envolvidas neste processo (CLARK; FUJIMOTO, 1991).

As nomenclaturas das fases do PDP não estão consolidadas na literatura, sendo que alguns autores identificam as atividades em momentos diferentes do processo. Para Clark e Wheelwright (1992) o PDP divide-se em quatro fases: desenvolvimento do conceito, planejamento do produto, engenharia do produto/processo e finalmente produção piloto/aumento da produção, conforme ilustrado na figura 3.

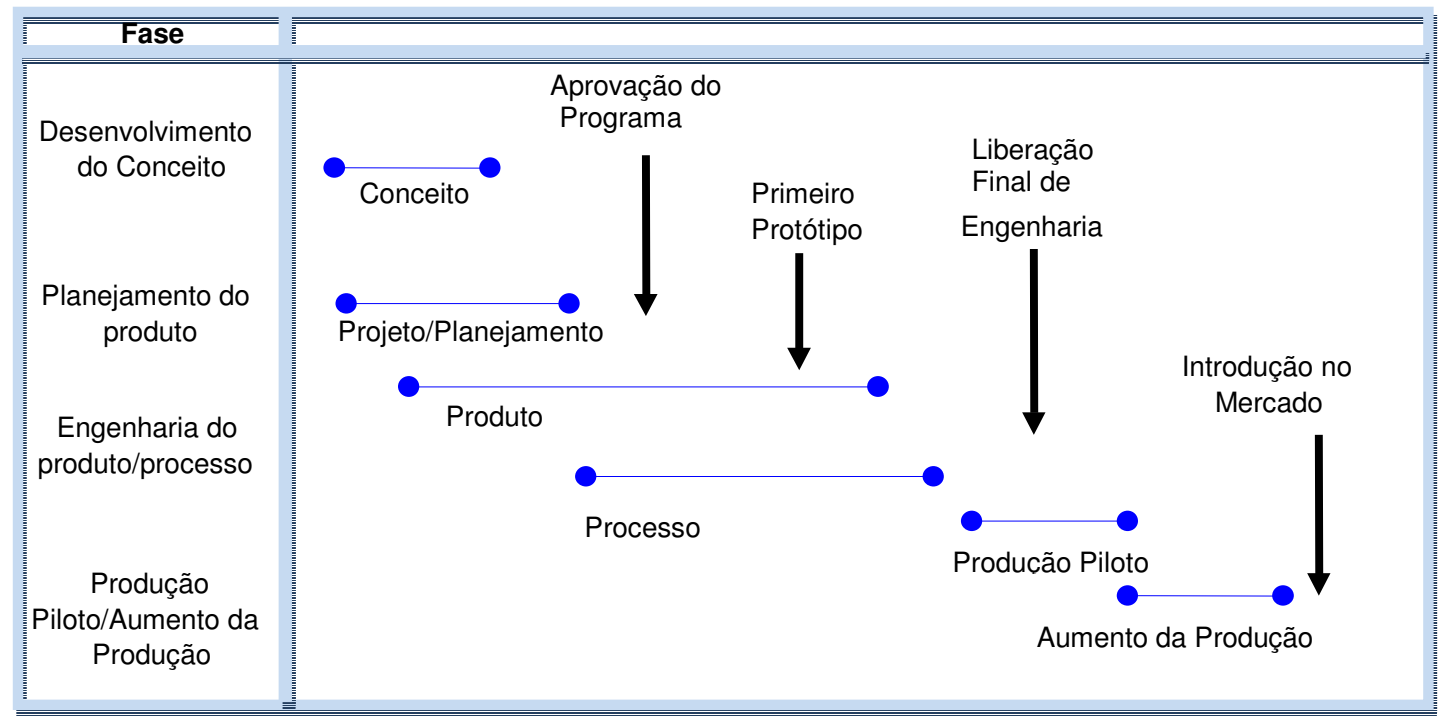

Figura 3 - Fases do desenvolvimento de novos produtos.

Fonte: Clark e Wheelwright (1992).

As duas primeiras fases compreendem o desenvolvimento do conceito e 0 planejamento do produto, que incluem informações sobre as oportunidades de mercado, as possibilidades técnicas e os requisitos de produção. Considera-se nestas fases o projeto conceitual, o mercado alvo, os investimentos necessários e a viabilidade econômica. Para a aprovação do programa, ou seja, para que o projeto continue a ser desenvolvido, o conceito deve ser validado através de testes e 
discussões com potenciais clientes. De acordo com os mesmos autores, o conceito aprovado segue para o detalhamento da engenharia e do processo de fabricação, sendo que esta fase envolve o desenvolvimento do projeto, a construção de protótipos e o desenvolvimento de ferramentas para produção. $O$ detalhamento de engenharia envolve o ciclo projetar, construir e testar, até atingir a maturidade necessária para início da produção piloto, sendo que a liberação da versão final encerra esta fase. A fase de produção piloto compreende a construção e teste dos meios de produção, nessa fase são produzidas muitas unidades do produto com 0 objetivo de testar os planos de processo desenvolvidos nos níveis de produção. $A$ conclusão desta fase certifica que todo o ferramental e equipamentos estão prontos, incluindo os fornecedores de peças, estando assim o produto pronto para início da produção em escala comercial (CLARK; WHEELWRIGHT, 1992). A última fase compreende o aumento do volume de produção, que envolve o refinamento do processo de produção, com aumento gradativo do volume até que a organização e os fornecedores atinjam confiança no processo e estejam aptos a atingir as metas planejadas de produção, custos e qualidade.

Seguindo esta linha de estruturação do PDP em fases, Rozenfeld (1997) apresentou um modelo de referência para o PDP, em que divide o PDP em diferentes fases: concepção, conceituação e projeto de produto e processo, que são semelhantes às fases de concepção, planejamento e engenharia do modelo de Clark e Wheelwright (1992), conforme mostrado anteriormente na figura 3. A diferença do modelo proposto por Rozenfeld (1997) fica com as fases de homologação, tanto de produto quanto de processo, que no caso do modelo de Clark e Wheelwright (1992) está implícito na fase de engenharia; e a fase de ensinar a empresa, que consiste na transmissão de informações sobre o produto e seus processos para as demais áreas da empresa, tais como marketing, engenharia do produto e manufatura, que tratarão de alguma forma do novo produto ou processo desenvolvido. O modelo de Rozenfeld (1997), visualizado na figura 4, destaca a necessidade de em todas as fases ser realizado uma avaliação propondo ações corretivas. 


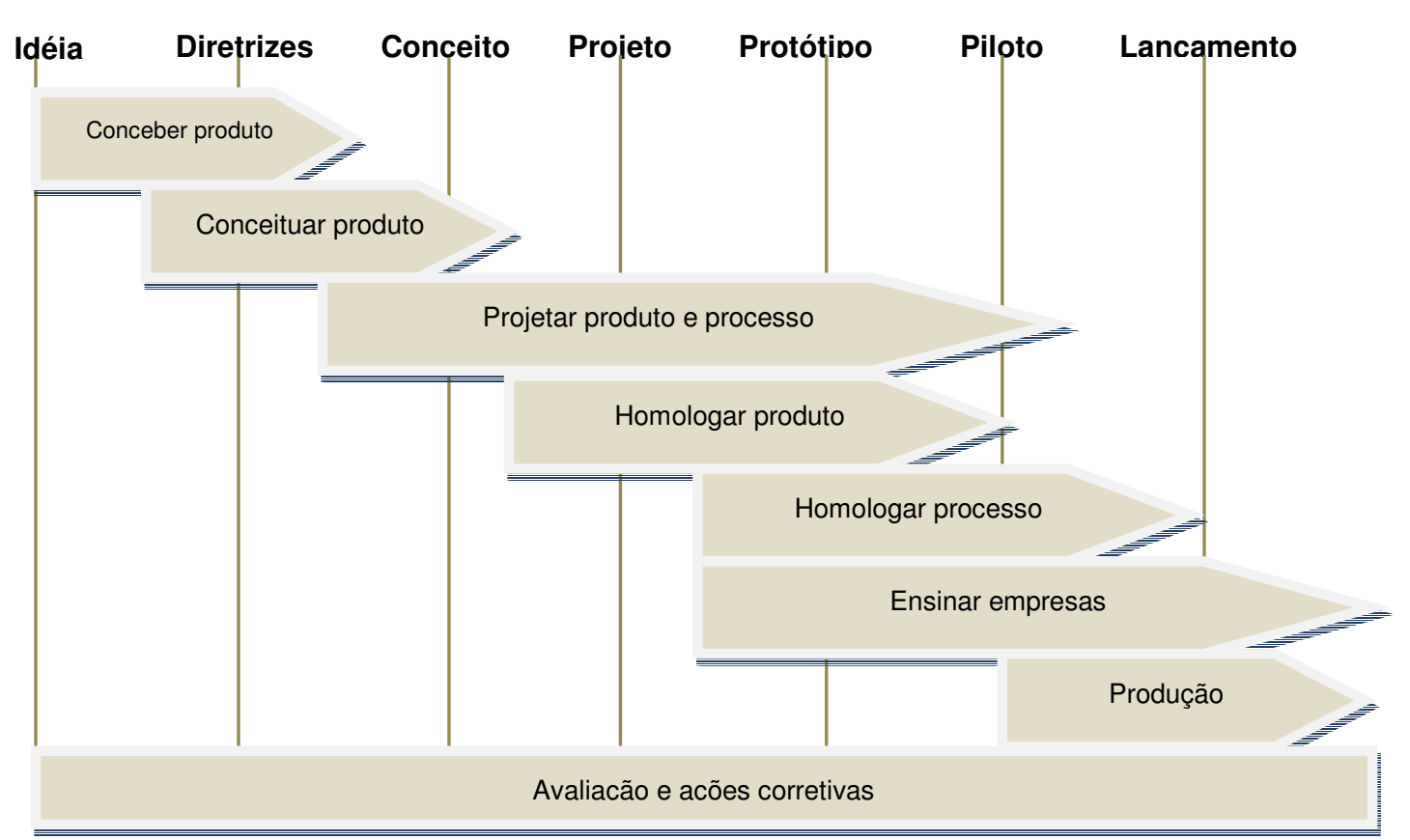

Figura 4 - Modelo de referência para o PDP.

Fonte: Rozenfeld (1997).

Devido à constante necessidade de aprimoramento do PDP, Rozenfeld et al. (2006) propõem uma atualização do seu modelo de referência para o PDP, incorporando novas fases e processos de apoio ao gerenciamento do processo, que busca identificar mudanças de melhoria incremental no desenvolvimento de novos produtos, através das atividades de gerenciamento de mudanças de engenharia e melhoria do PDP.

O novo modelo, visualizado na figura 5, está dividido em três macros fases: inicia com a fase de pré-desenvolvimento, que engloba as fases de planejamento estratégico de produtos e planejamento do projeto; em seguida pela fase de desenvolvimento, que engloba o projeto conceitual, projeto detalhado, preparação da produção do produto e lançamento do produto; e finaliza com a fase de pósdesenvolvimento, que tem o objetivo de acompanhar o produto e processo e descontinuar o produto do mercado. 


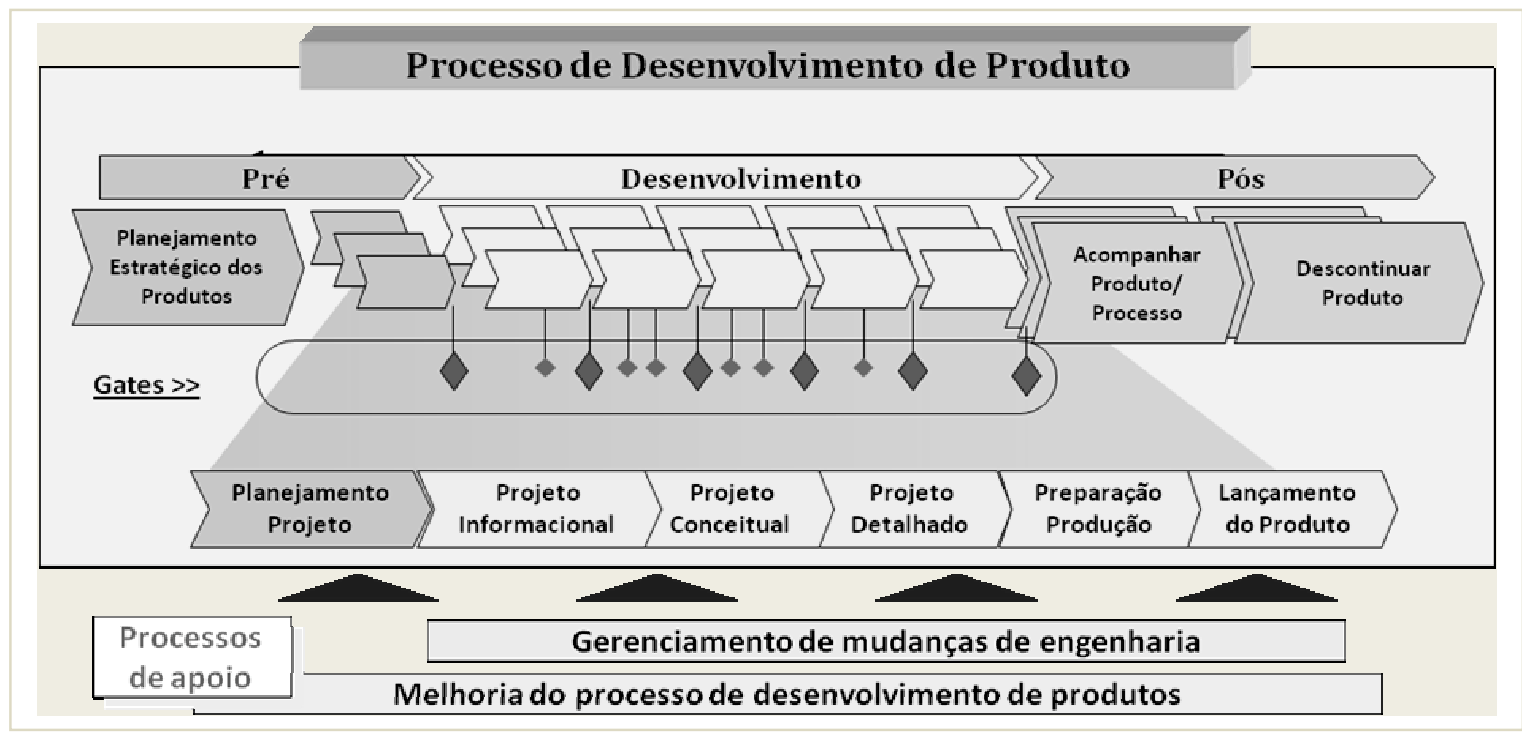

Figura 5 - Atualização do modelo de referência para o PDP.

Fonte: Rozenfeld et al. (2006).

De acordo com Cooper (1993) entre cada fase do PDP existe um processo de revisão de fases, que consiste em uma revisão gerencial que ocorre geralmente no final de cada fase e avalia a possibilidade de continuação do projeto e os riscos envolvidos nesta decisão. Estas decisões são baseadas em critérios bem definidos, que abrangem todas as áreas da empresa, de modo a considerar todas as características do projeto. Para a tomada destas decisões, devem-se considerar as revisões de portfólio e as revisões de fase conforme mostra a figura 6 .
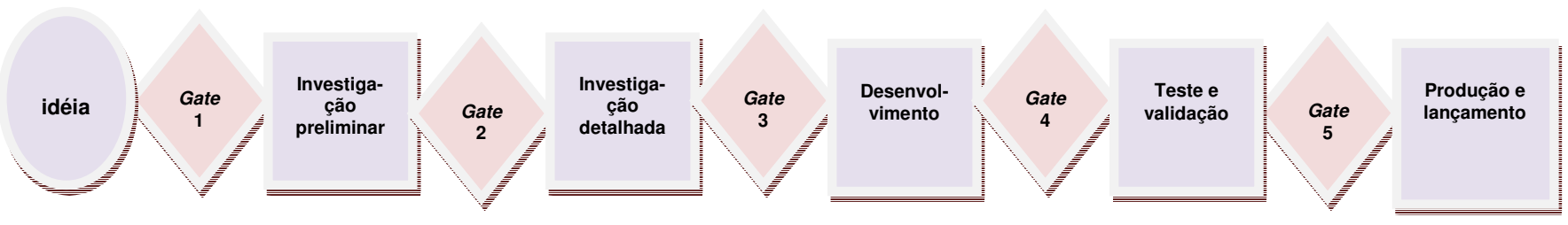

Figura 6 - Processo de revisão de fases no PDP.

Fonte: Elaborado pelo autor com base em Cooper (1993).

Os resultados de uma revisão de fases incluem a decisão e um plano de ação, no qual a decisão pode ser continuar o projeto sem problemas, cancelar, congelar para posterior reinício de atividades, e redirecionar atividades (VALERI, 2000). Visto que, 
o plano de ação deve conter o redirecionamento das atividades ou um plano de projeto para a próxima fase, com a lista de critérios da próxima revisão de fases.

Os times que participam no PDP e conseqüentemente nas revisões de fases apresentam papéis diferentes, desde a decisão efetiva no processo, passando pela condução e execução do projeto. A decisão é tomada geralmente por um time composto por pessoas da alta administração, enquanto a condução do projeto é realizada pelo time de projeto e a execução dos trabalhos é feita pela equipe do projeto.

Esta divisão de fases é bastante razoável, dado que ela baseia-se nos tipos de atividade e numa seqüência lógica de entradas e saídas, de acordo com a interdependência dos diferentes tipos de atividades. Mas, na prática, Amaral (1997) comenta que tais fases, como mandam a natureza interativa das atividades do PDP, se sobrepõem e interagem continuamente, assim como as pessoas envolvidas no processo.

A importância da aplicação de revisão de fases é ressaltada por Griffin (1997), que realizou uma revisão sobre as melhores práticas das empresas em PDP, separando entre as empresas que obtém sucesso no lançamento de novos produtos e as demais. Este mesmo autor observou que a maioria das empresas de sucesso utiliza o processo de revisão de fases de forma consistente.

Além da estrutura de revisão de fases, existe outra forma de visualização do PDP, que é por meio do conceito do funil de desenvolvimento apresentado por Clark e Wheelwright (1993) e utilizado como um modelo de estratégia de desenvolvimento de novos produtos. Este conceito preocupa-se em preencher algumas necessidades estratégicas, como: criar, definir e selecionar projetos que poderão gerar produtos superiores; integrar e coordenar tarefas funcionais e técnicas, bem como as unidades envolvidas; gerenciar os esforços do desenvolvimento coerentemente com as metas do negócio; e melhorar as capacidades necessárias para tornar o PDP uma fonte de vantagem competitiva (CLARK; WHEELWRIGHT, 1993). É importante lembrar que no início do funil, são desenvolvidas as atividades de levantamento e avaliação tanto de mercado quanto da tecnologia. Assim como, dentro da atividade de aprendizagem pós-projeto, está embutida a busca pela melhoria contínua do PDP, pois são considerados diversos pontos para avaliação e alavancagem, desde o uso de ferramentas até a análise crítica do processo. A estrutura do funil de desenvolvimento de produtos está esquematizada na figura 7 . 


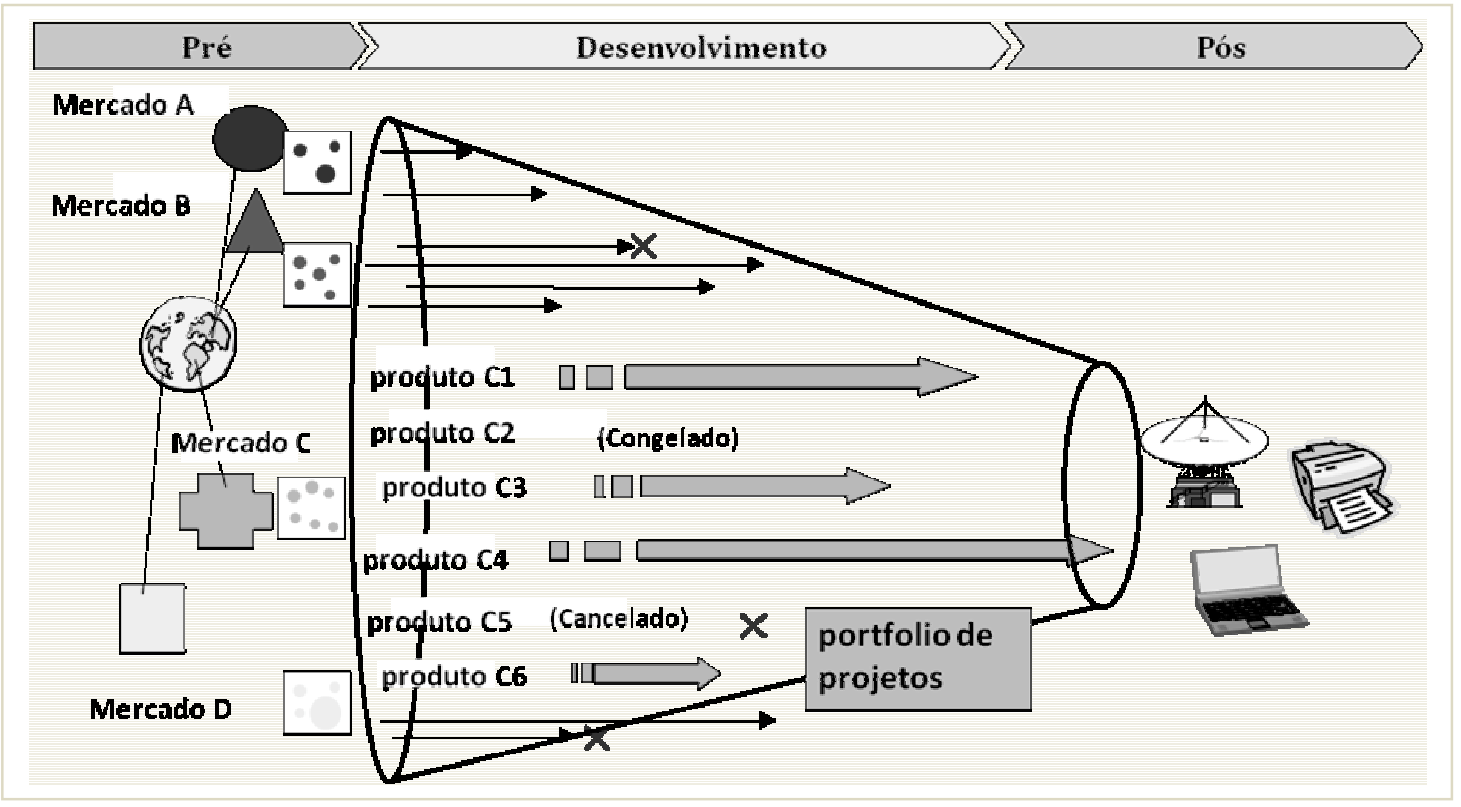

Figura 7 - Funil de desenvolvimento de novos produtos.

Fonte: Clark e Wheelwright (1993).

Após apresentada a estratégia de levantar e avaliar o mercado e a tecnologia para escolher projetos que poderão gerar produtos ou processos de sucesso, outro fator de destaque no PDP é o de distinguir os tipos de projetos a serem desenvolvidos para melhor planejar alocação dos recursos. O nível de mudança no produto e no processo de fabricação pode ser combinado para classificar diversos tipos de projetos de desenvolvimento.

Os principais tipos de projetos referentes à amplitude da mudança de projeto ou processo são classificados, conforme Clark e Wheelwright (1993), em: a) projetos incrementais e derivados, que são projetos de melhorias variando de versões de custo reduzido de um produto ou processo existente; b) projetos próxima geração ou plataforma, que são projetos envolvendo mudanças significativas tanto no produto quanto no processo de fabricação; c) projetos inovações radicais, que envolvem mudanças significativas no produto e processo, estabelecendo um novo núcleo de processos e que representam uma nova aplicação para o produto; d) projetos de pesquisa e desenvolvimento avançado, que são projetos conduzidos internamente na organização, com o foco no desenvolvimento avançado e de pesquisa utilizando a geração de conhecimento como um precursor do desenvolvimento; e por último e) projetos de alianças ou de parceria, que são projetos conduzidos de um modo 
diferente, pois se utiliza de parceria com outra organização para conduzir P\&D e para desenvolver novos conceitos de produtos. Estes tipos de projetos são caracterizados na figura 8 , de acordo com a amplitude da mudança do projeto ou processo.

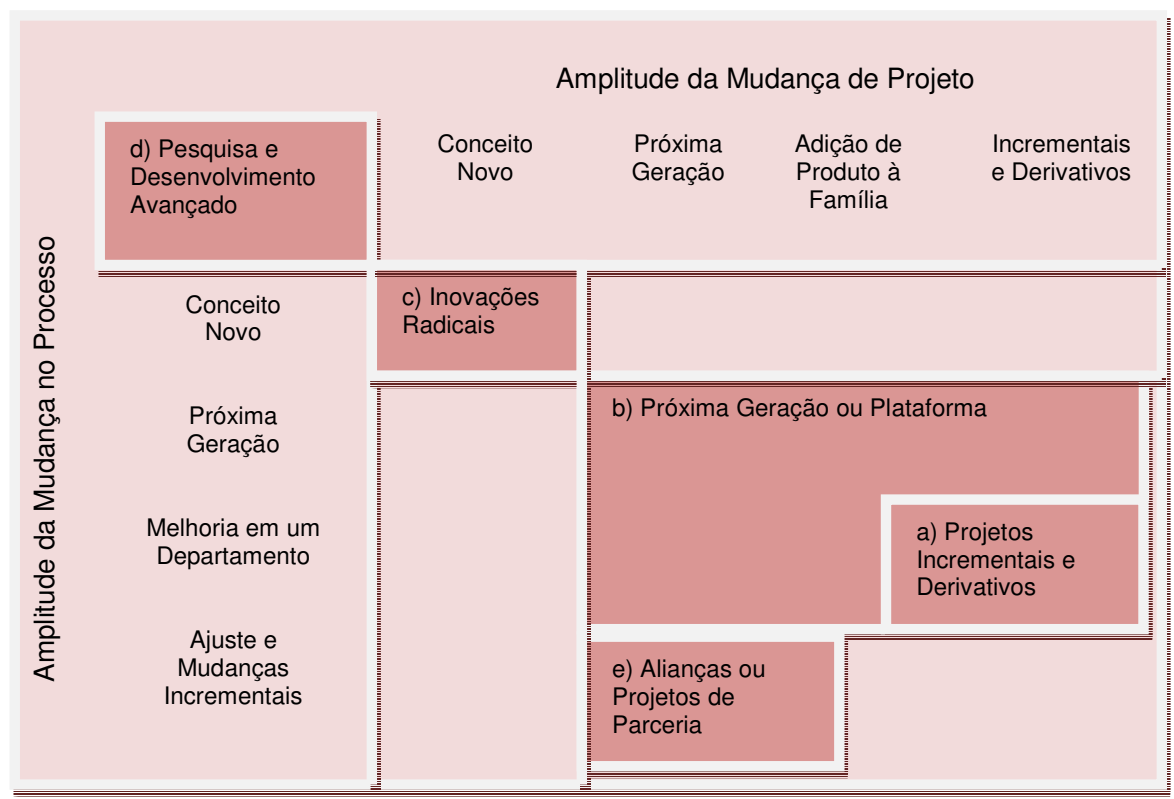

Figura 8 - Tipos de projetos baseados na inovação no PDP.

Fonte: Clark e Wheelwright (1993).

Em estudo mais recente, Garcia e Calantone (2002) identificam outras formas de classificar os projetos de desenvolvimento de novos produtos, de acordo com o grau de inovação. A classificação dos projetos se divide nos seguintes tipos: incremental e radical; incremental, modular, arquitetural e radical; evolucionário e revolucionário; e sustentador e disruptivo. Nesta classificação, os autores utilizam de duas variáveis, a primeira denominada de perspectiva micro ou macro, sendo que uma inovação micro é definida quando o produto gerado é novo para a empresa ou para o cliente, e uma inovação macro quando o produto é novo para o mundo. Na segunda denominada de descontinuidade tecnológica ou de mercado, é considerada a força que gera a descontinuidade, seja pelo surgimento de novos mercados ou por avanços tecnológicos. Portanto, com base nas duas variáveis identificadas os autores propõem uma uniformização no grau de inovação dos projetos de desenvolvimento de novos produtos, tendo a seguinte classificação (GARCIA; CALANTONE, 2002): inovação radical, que introduz macro descontinuidades 
tecnológicas e de mercado; inovação really new, que introduz apenas uma das macros descontinuidades tecnológicas e de mercado; e inovação incremental, que introduz micro descontinuidades tecnológicas e de mercado.

Além dos tipos de projetos a serem desenvolvidos outros fatores interferem diretamente na condução do PDP, sendo a complexidade um deles. Segundo Clark e Fujimoto (1991) a complexidade do PDP pode estar relacionada à complexidade do produto e a complexidade organizacional, dependendo das características do produto a ser desenvolvido.

A complexidade do produto está ligada a estrutura do produto e as interfaces com o usuário. Sendo que, a estrutura do produto se refere à consistência da função do produto, e geralmente é alcançada através da coordenação interfuncional da empresa e dos seus fornecedores. A interface com o usuário se refere à consistência entre o desempenho do produto e as expectativas do consumidor. Em mercados turbulentos e dinâmicos, a interface com o usuário é crítica para a competitividade dos novos produtos. Nesse caso, as empresas precisam antecipar 0 que os consumidores esperam do produto, integrando as expectativas do consumidor com o trabalho de desenvolvimento de novos produtos.

A complexidade organizacional está relacionada à complexidade do produto e implica em alta interdependência de subsistemas, esta complexidade aumenta na medida em que mais áreas e pessoas são envolvidas no PDP e conseqüentemente requer uma maior coordenação do processo. Portanto, o gerenciamento dessas duas complexidades impõe uma pressão sobre as pessoas envolvidas que, geralmente, têm diferentes interesses com o PDP.

De acordo com Rozenfeld et al. (2006) distinguir os tipos de projetos é importante para melhorar a atuação gerencial em termos de planejar, alocar pessoal, e guiar projetos individuais. Além disso, auxilia as empresas na escolha do melhor arranjo organizacional para se conduzir o PDP, conforme as características da empresa e do tipo de projeto a ser desenvolvido.

Para se estruturar o PDP, as empresas utilizam de arranjos organizacionais que podem aparecer de diferentes formas (SOUSA MENDES; TOLEDO, 2003): funcional, autônoma ou por projeto e matricial. A escolha da estrutura adequada deve estar alinhada as questões estratégicas e refletir a cultura da organização. 
$\mathrm{Na}$ estrutura funcional as atividades necessárias para a execução de um determinado projeto ficam alocadas nas suas respectivas áreas de atuação. Neste tipo de arranjo, cada gerente funcional é responsável pelo controle dos recursos e atividades desempenhadas em sua área (CLARK; FUJIMOTO, 1991). Esta estrutura destaca como vantagem a própria especialização, que conduz ao aumento da capacitação técnica e gera maior comprometimento entre os envolvidos. Quanto às suas limitações, a estrutura funcional é carente de maior coordenação e integração no PDP, principalmente nos projetos multifuncionais. Na estrutura funcional, a ligação entre os participantes acontece entre aqueles que realizam funções similares, conforme ilustra a figura 9.

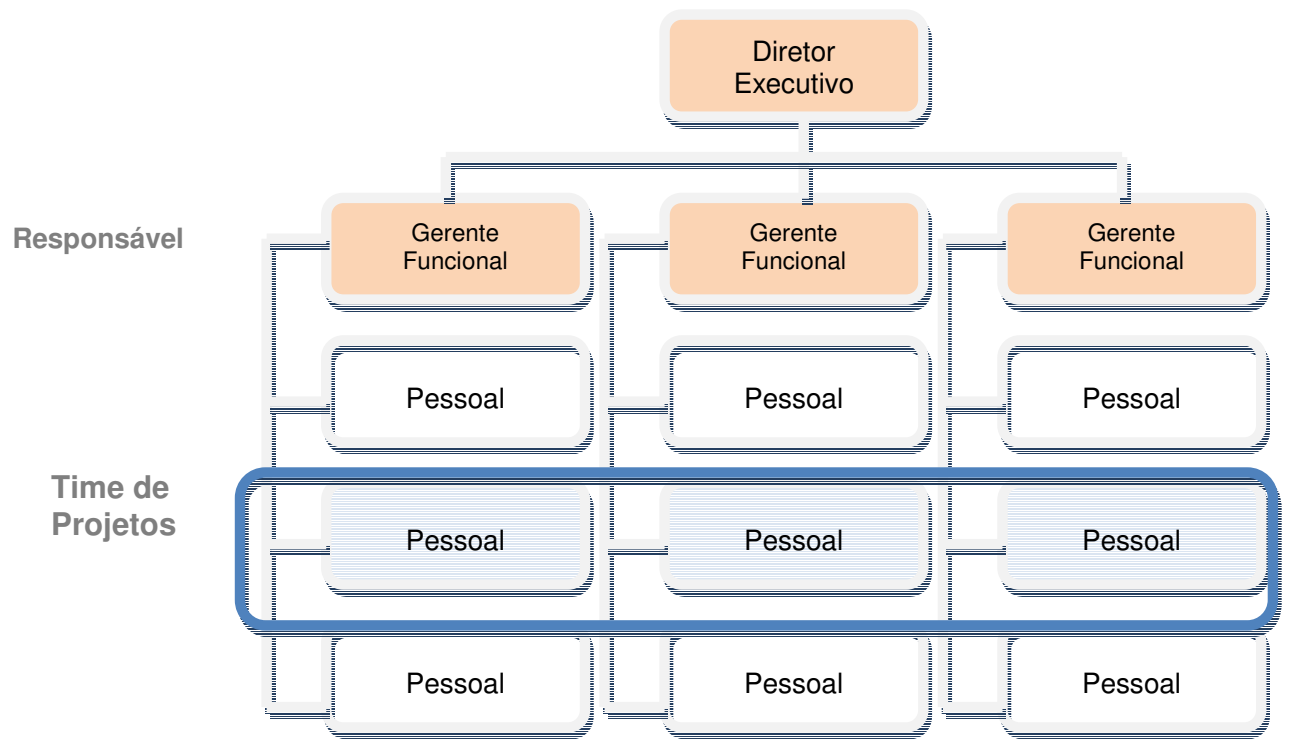

Figura 9 - Estrutura funcional no PDP.

Fonte: Rozenfeld et al. (2006).

$\mathrm{Na}$ estrutura autônoma ou por projeto, os recursos da organização para o PDP são alocados em torno de projetos e gerentes de projetos. A integração acontece nas reuniões com pessoas de outras áreas, que trabalham totalmente ou parcialmente no time responsável pela condução do projeto. A vantagem desta estrutura é o foco, e sua desvantagem está na realocação de recursos após o final do projeto (VASCONCELLOS; HEMSLEY, 2000). Neste tipo de estrutura, a ligação entre os integrantes acontece entre os que estão trabalhando em um mesmo projeto, de acordo com a figura 10. 


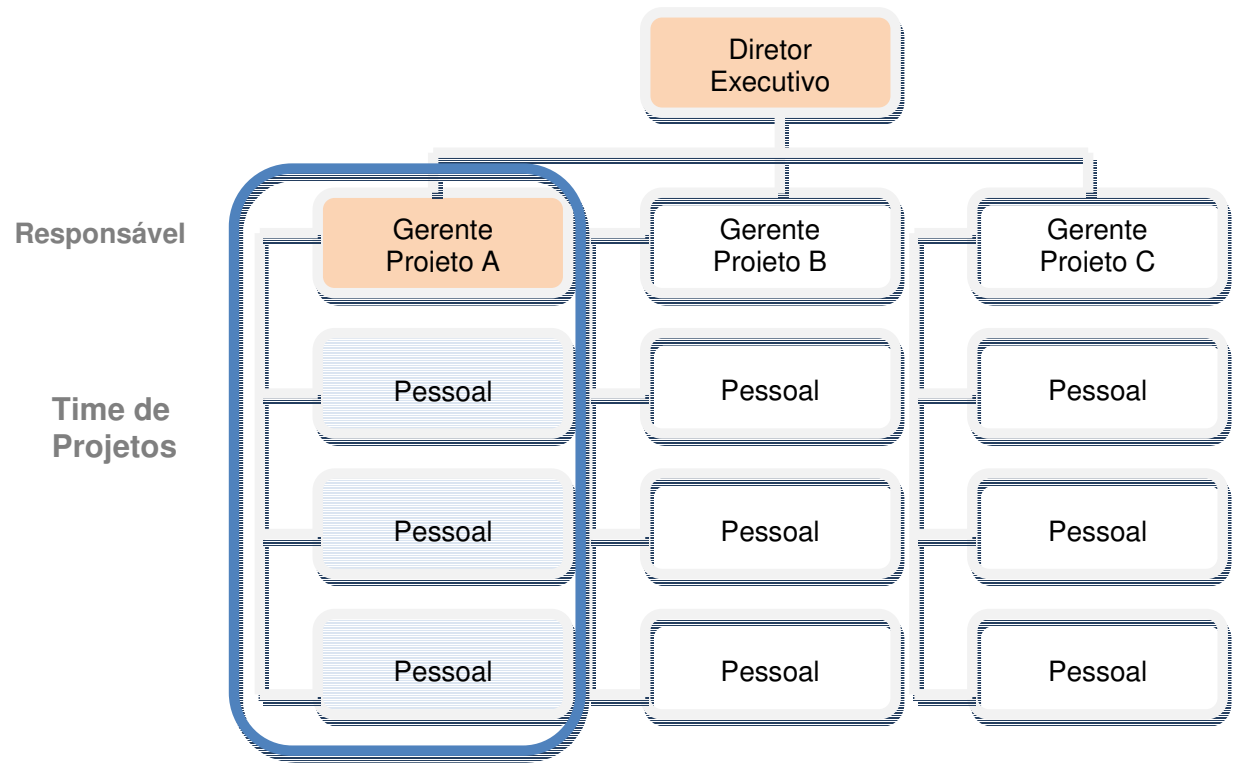

Figura 10 - Estrutura autônoma ou por projeto no PDP.

Fonte: Rozenfeld et al. (2006).

A estrutura matricial surgiu da mistura da estrutura funcional e da estrutura autônoma ou por projeto, devido ao aumento da complexidade e da necessidade de maior integração (ROZENFELD et al., 2006). Tanto que a esta estrutura apresenta características das duas estruturas funcionais, agrupando as pessoas e os recursos simultaneamente por função e por projetos. Normalmente, o gerente funcional limitase à execução técnica, enquanto o gerente de projeto coordena o projeto em si. $\mathrm{Na}$ estrutura matricial, os participantes estão ligados a outros integrantes do PDP por meio de suas áreas funcionais e por projetos, conforme mostra a figura 11.

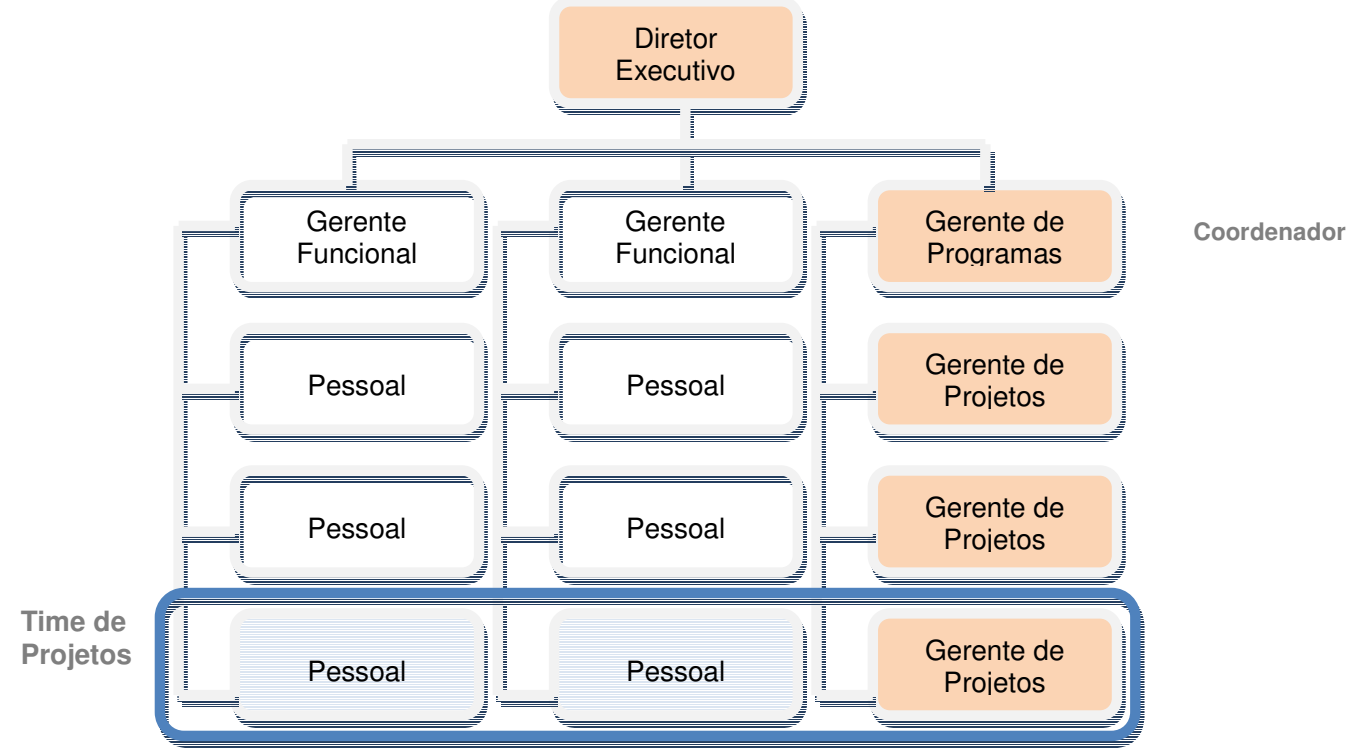

Figura 11 - Estrutura matricial no PDP.

Fonte: Rozenfeld et al. (2006). 
Devido à dificuldade de compartilhamento hierárquico dos funcionários envolvidos com o PDP, surgiram duas variações da estrutura matricial (CLARK; FUJIMOTO, 1991; CLARK; WHEELWRIGHT, 1993): estrutura de projeto peso leve, no qual os participantes ficam em suas áreas funcionais, no qual é designado um gerente "peso leve" responsável por coordenar o projeto, e que se encontra numa posição inferior aos gerentes funcionais quanto à autoridade e poder; e estrutura de projeto peso pesado, que se caracteriza por maior poder na organização por projeto, além de existir a figura do gerente "peso pesado", que são gerentes seniores com acesso direto e responsabilidade pelo trabalho de todos os envolvidos no projeto.

A seguir, a tabela 2 resume as principais características destes tipos de estrutura organizacional, e relaciona para que tipos de projetos eles se mostrem mais adequado.

Tabela 2 - Tipos de arranjos organizacionais para o PDP.

\begin{tabular}{c|c|c|c|c}
\hline $\begin{array}{c}\text { TIPO DE } \\
\text { ARRANJO }\end{array}$ & FUNCIONAL & $\begin{array}{c}\text { AUTONOMA OU } \\
\text { POR PROJETO }\end{array}$ & $\begin{array}{c}\text { MATRICIAL } \\
\text { PESO LEVE }\end{array}$ & $\begin{array}{c}\text { MATRICIAL } \\
\text { PESO PESADO }\end{array}$ \\
\hline $\begin{array}{c}\text { Autonomia do } \\
\text { gerente de projeto }\end{array}$ & $\begin{array}{c}\text { Pouca ou } \\
\text { Nenhuma }\end{array}$ & Alta & Baixa & Alta \\
$\begin{array}{c}\text { Controle sobre o } \\
\text { projeto }\end{array}$ & $\begin{array}{c}\text { Compartilhada } \\
\text { entre o gerente de } \\
\text { projeto e os } \\
\text { gerentes } \\
\text { funcionais }\end{array}$ & $\begin{array}{c}\text { Total pelo gerente } \\
\text { do projeto }\end{array}$ & $\begin{array}{c}\text { Compartilhada } \\
\text { entre o gerente de } \\
\text { projeto e os } \\
\text { gerentes } \\
\text { funcionais }\end{array}$ & $\begin{array}{c}\text { Total pelo gerente } \\
\text { do projeto }\end{array}$ \\
\hline $\begin{array}{c}\text { Alocação do } \\
\text { gerente de projeto }\end{array}$ & Tempo Parcial & Tempo Integral & Tempo Parcial & Tempo Integral \\
\hline $\begin{array}{c}\text { Comunicação } \\
\text { entre o gerente do } \\
\text { projeto e o time }\end{array}$ & Indireta & Direta & Direta \\
\hline Tipos de projeto & Inovação & Inovação radical & $\begin{array}{c}\text { Inovação } \\
\text { incremental com } \\
\text { alto grau de } \\
\text { complexidade }\end{array}$ & Inovação tipo \\
plataforma
\end{tabular}

Fonte: Adaptado pelo autor de Clark e Wheelwright (1993).

Com o objetivo de detalhar os principais papéis das pessoas envolvidas no PDP, é descrito resumidamente a seguir os mais importantes para este trabalho, com base nas definições utilizadas no modelo de referência de Rozenfeld et al. (2006):

- Gerente funcional, que é responsável por uma função específica da empresa;

- Gerente de projetos, que é responsável por um projeto e líder de um time de desenvolvimento; 
- Especialistas, que são pessoas de determinadas áreas funcionais da empresa, que possuem conhecimento técnico empregado no processo de fabricação;

- Time de desenvolvimento, que é responsável por um projeto específico de desenvolvimento, esta equipe pode ser formada por pessoas de diversas áreas (marketing, engenharia do produto e manufatura).

Em consonância, a importância da escolha da estrutura organizacional adequada à empresa, Hultink e Robben (1995) mencionam que o monitoramento do PDP por meio de indicadores de desempenho impacta positivamente no sucesso do desenvolvimento de novos produtos. A literatura sobre este assunto aponta vários indicadores de desempenho e medidas de sucesso para o PDP, de caráter financeiro ou operacional, que estão ligados ao desempenho do produto no mercado ou ao seu respectivo desenvolvimento.

Diversos estudos foram realizados sobre a utilização de indicadores de desempenho no PDP, um deles foi elaborado por Griffin e Page (1993) que analisou os principais indicadores utilizados por pesquisadores e pelas empresas. Este estudo resultou nos seguintes tipos de avaliação: indicadores de benefícios das empresas; indicadores do produto; indicadores de desempenho financeiro; indicadores do projeto; e indicadores de aceitação do consumidor. Esses tipos de avaliação e os respectivos indicadores são descritos a seguir na tabela 3.

Tabela 3 - Principais indicadores de sucesso no PDP.

\begin{tabular}{ll}
\hline \multicolumn{1}{c}{ ACEITAÇÃO DO CONSUMIDOR } & \multicolumn{1}{c}{ PRODUTO } \\
\hline Aceitação do consumidor & Custo de desenvolvimento \\
\hline Satisfação do consumidor & Lançamento no tempo planejado \\
\hline Metas de vendas & Nível de desempenho do produto \\
\hline Crescimento de vendas & Diretrizes de qualidade atingidas \\
\hline Metas de participação de mercado & Velocidade de lançamento do produto \\
\hline Metas de unidades de venda & \\
\hline \multicolumn{1}{c}{ DESEMPENHO FINANCEIRO } \\
\hline Tempo de retorno de investimento \\
\hline Metas de margem & EMPRESA \\
\hline Metas de lucratividades & \\
\hline Taxa Interna de Retorno (TIR)/Return on Investment (ROI) & \\
\hline Fonte: Griffin e Page (1993).
\end{tabular}


Esta pesquisa foi aperfeiçoada por Hultink e Robben (1995), que mostraram que a importância de cada um destes indicadores depende da perspectiva de tempo; do mercado em que o produto estiver situado; e da estratégia de inovação de produtos da empresa.

Outros autores pesquisaram as medidas de sucesso e falha no PDP buscando indicadores que podem ser utilizados para avaliação de desempenho. Uma proposta de indicadores de desempenho no PDP é apresentada por Driva et al. (2000), como resultado de uma pesquisa internacional que estudou os indicadores recomendados pelos acadêmicos e utilizados pelas empresas. Estes indicadores de desempenho são mostrados na tabela 4.

Tabela 4 - Indicadores de desempenho utilizados por empresas no PDP.

\begin{tabular}{l|c}
\hline \multicolumn{1}{c|}{ INDICADORES } & $\%$ DE USO \\
\hline \hline Custo total do projeto & 71 \\
\hline Desenvolvimento no tempo planejado & 61 \\
\hline Custo real X custo orçado & 60 \\
\hline Tempo real X planejado & 58 \\
\hline Tempo de lançamento ao mercado & 57 \\
\hline Teste de campo visando à produção & 54 \\
\hline Análise da lucratividade projetada & 51 \\
\hline Tempo de desenvolvimento do fornecedor & 49 \\
\hline Razões para falhas no mercado & 46 \\
\hline Aprovação do protótipo nos testes de segurança & 45 \\
\hline Orçamento de P\&D com \% de vendas & 43 \\
\hline Tempo gasto em cada fase do desenvolvimento & 42 \\
\hline Metas de qualidade do produto atingidas & 39 \\
\hline Lucro real X previsto nos produtos & 35 \\
\hline Fonte: Driva et al (2000)
\end{tabular}
Fonte: Driva et al. (2000).

Para Prancic e Martins (2003) as empresas devem definir os indicadores de desempenho direcionados para cada função participante do PDP, pois estas pessoas (gerente do PDP, gerente de programa e coordenador da fase) têm que tomar decisões diferentes e, portanto necessitam de diferentes tipos de informações. Os mesmos autores destacam que cada empresa deve utilizar indicadores mais apropriados ao seu negócio e também deve procurar medir a satisfação do cliente com os produtos desenvolvidos. Seguindo neste conceito de alinhar o PDP aos objetivos estratégicos da empresa, Rozenfeld et al. (2006) destaca a importância de existir indicadores de produtividade que avaliem todos os produtos de maneira igual. $\mathrm{Na}$ tabela 5 são listados os indicadores de produtividade utilizados por empresas. 
Tabela 5 - Indicadores utilizados por empresas para medir a produtividade do PDP.

\begin{tabular}{l|c}
\hline \multicolumn{1}{c|}{ INDICADOR } & $\%$ \\
\hline \hline Porcentagem dos gastos em desenvolvimentos sobre as vendas & 68 \\
\hline Total de patentes registradas & 50 \\
\hline Porcentagem das vendas resultantes de novos produtos nos últimos 5 anos & 47 \\
\hline Quantidade de produtos lançados no ano & 46 \\
\hline Crescimento de gastos em desenvolvimento de novos produtos & 43 \\
\hline Quantidade de projetos de desenvolvimentos ativos & 42 \\
\hline Vendas no primeiro ano resultantes de novos produtos & 32 \\
\hline Retorno de investimentos das inovações & 32 \\
\hline Porcentagem de recursos / investimentos em sustentabilidade & 30 \\
\hline Faturamento sobre pessoal de desenvolvimento & 17 \\
\hline Porcentagem de produtos / projetos aceitos / rejeitados & 12 \\
\hline Média de produtos lançados por pessoa de desenvolvimento & 9 \\
\hline
\end{tabular}

Fonte: Rozenfeld et al. (2006).

Tão importante quanto à utilização destes indicadores de desempenho no PDP, existem algumas ações no sentido de conduzir o desenvolvimento de produtos para o sucesso (COOPER, 1993; ROZENFELD et al., 2006): o produto deve ser diferenciado proporcionando benefícios ao cliente; ter orientação para um mercado atrativo; ter velocidade para lançar o novo produto; deve-se dedicar mais tempo à fase de pré-desenvolvimento; é importante estruturar o PDP em fases; integrar as áreas envolvidas no PDP; e alinhar o PDP as estratégias da empresa.

Inserido nestes fatores gerenciais que afetam o desempenho do PDP, citados anteriormente, a integração interfuncional se destaca para os propósitos deste trabalho. Portanto, será analisada na seção a seguir, com ênfase nos conflitos e formas de integração entre as principais áreas envolvidas no PDP.

\subsubsection{A importância da integração interfuncional no PDP}

Esta parte do referencial teórico aborda a integração interfuncional no PDP, realizando uma análise nos principais geradores de conflitos entre as áreas envolvidas, e detalhando a importância da integração para o sucesso do PDP.

Em empresas de manufatura podem existir conflitos entre as funções envolvidas no PDP (marketing, engenharia do produto e manufatura), estas áreas apresentam um relacionamento complexo, devido à natureza dos seus objetivos. Portanto, uma interface de consenso entre estas funções é essencial. Uma vez que, com a crescente exigência dos clientes por novos produtos, os conflitos se tornaram mais 
freqüentes e a relação das áreas mais complexas, ficando cada vez mais difícil perceber os objetivos da empresa como um todo e de cada área (ALTAMIRANO, 1999).

A integração interfuncional no PDP representa uma meta para as empresas, pois é difícil de ser alcançada. A atuação de várias áreas no PDP aproxima e indica uma integração melhor entre as áreas, embora esta mesma atuação proporcione conflitos que dificultam a integração. Segundo Clark e Wheelwright (1993) a integração é importante para o PDP, sendo que todas as alternativas para se reduzir o tempo de desenvolvimento direcionam cada vez mais ao trabalho em equipe. Considerando esta importância de se atuar de forma integrada, especialmente das áreas diretamente envolvidas no PDP, para o sucesso dos novos produtos no mercado, essas alternativas geram um cenário de interfuncionalidade, que se torna o ponto central na condução do PDP.

A estrutura funcional das empresas teve origem na divisão do trabalho, ligada a especialização, que dividiu o conhecimento em várias unidades na estrutura organizacional das empresas (SOUSA MENDES; TOLEDO, 2003). No entanto, a dinâmica dessa estrutura organizacional acontece por processos contínuos, que engloba simultaneamente vários conhecimentos situados em áreas diferentes da empresa, ocasionando dependência de recursos e conseqüentemente afetando os fluxos de comunicação entre as diferentes áreas envolvidas no PDP.

O grau com que as funções se relacionam determina a efetividade da integração no PDP, pois o resultado do trabalho de uma determinada área será a entrada para a atividade de outra conforme detalhamento das atividades por áreas da tabela 6.

Tabela 6 - Atividades funcionais de integração interfuncional no PDP.

\begin{tabular}{l|l|l|l}
\hline \multicolumn{1}{c|}{ ATIVIDADES } & \multicolumn{1}{c|}{ MARKETING } & \multicolumn{1}{c}{$\begin{array}{c}\text { ENGENHARIA DO } \\
\text { PRODUTO }\end{array}$} & \multicolumn{1}{c}{ MANUFATURA } \\
\hline & $\begin{array}{l}\text { Ter uma visão baseada } \\
\text { no mercado e investigar } \\
\text { Desenvolvimento do } \\
\text { conceitos de produto }\end{array}$ & $\begin{array}{l}\text { Buscar novas } \\
\text { tecnologias, } \\
\text { desenvolver idéias de } \\
\text { produto, construir } \\
\text { modelos e conduzir } \\
\text { simulações }\end{array}$ & $\begin{array}{l}\text { Investigar conceitos de } \\
\text { produto }\end{array}$ \\
\hline
\end{tabular}

Fonte: Adaptado pelo autor de Clark e Wheelwright (1993). 
Tabela 6 - Atividades funcionais de integração interfuncional no PDP - Continuação.

\begin{tabular}{l|l|l|l}
\hline \multicolumn{1}{c|}{ ATIVIDADES } & \multicolumn{1}{|c|}{ MARKETING } & \multicolumn{1}{c|}{$\begin{array}{c}\text { ENGENHARIA DO } \\
\text { PRODUTO }\end{array}$} & \multicolumn{1}{c}{ MANUFATURA } \\
\hline \hline $\begin{array}{l}\text { Planejamento do } \\
\text { produto }\end{array}$ & $\begin{array}{l}\text { Definir os parâmetros } \\
\text { dos consumidores, } \\
\text { desenvolver estimativas } \\
\text { de vendas e margens, } \\
\text { conduzir interação } \\
\text { preliminar com clientes }\end{array}$ & $\begin{array}{l}\text { Definir componentes e } \\
\text { interagir com } \\
\text { fornecedores, construir } \\
\text { os protótipos e definir a } \\
\text { arquitetura do sistema }\end{array}$ & $\begin{array}{l}\text { Fazer estimativas de } \\
\text { custo, definir arquitetura } \\
\text { do processo, conduzir } \\
\text { simulação do processo } \\
\text { e validar junto aos } \\
\text { fornecedores }\end{array}$ \\
\hline $\begin{array}{l}\text { Engenharia do } \\
\text { produto/processo }\end{array}$ & $\begin{array}{l}\text { teste de protótipos junto } \\
\text { aos clientes, } \\
\text { estabelecer plano de } \\
\text { distribuição }\end{array}$ & $\begin{array}{l}\text { Fazer e refinar } \\
\text { detalhamento do } \\
\text { produto, interagir com o o } \\
\text { processo, construir e } \\
\text { testar protótipos }\end{array}$ & $\begin{array}{l}\text { Fazer detalhamento do } \\
\text { processo, projetar e } \\
\text { desenvolver } \\
\text { maquinaria, participar } \\
\text { na construção de } \\
\text { protótipos e elaborar } \\
\text { procedimentos }\end{array}$ \\
\hline $\begin{array}{l}\text { Produção } \\
\text { piloto/Aumento da } \\
\text { produção }\end{array}$ & $\begin{array}{l}\text { Treinar força de vendas } \\
\text { e preparar sistema de } \\
\text { registro }\end{array}$ & $\begin{array}{l}\text { Avaliar e testar } \\
\text { unidades piloto e } \\
\text { resolver problemas }\end{array}$ & $\begin{array}{l}\text { Produzir unidades } \\
\text { piloto, refinar processo, } \\
\text { treinar pessoal e } \\
\text { verificar a cadeia de } \\
\text { suprimentos }\end{array}$ \\
\hline
\end{tabular}

Fonte: Adaptado pelo autor de Clark e Wheelwright (1993).

De acordo com Clark e Wheelwright (1995), um elemento crítico para a integração entre diferentes áreas no PDP são as barreiras de comunicação adotadas pelas empresas. Os mesmos autores consideram alguns tópicos para uma comunicação de melhor qualidade, que são: riqueza da informação, freqüência, direção e momento em que ocorre. A maneira como às áreas lidam com cada um desses tópicos de comunicação interfere diretamente na integração das áreas envolvidas no desenvolvimento de novos produtos.

Alguns trabalhos têm sido desenvolvidos sobre a importância da interação das áreas envolvidas no PDP (marketing, engenharia do produto e manufatura) para 0 sucesso do desenvolvimento de novos produtos. Visto que, cada área contribui de acordo com seus conhecimentos específicos para o PDP, e esta interação e troca de informações, entre o time multidisciplinar de desenvolvimento de novos produtos, gera inovação de produtos conforme as necessidades dos clientes. Esta interação impulsiona a busca por formas de melhorar a cooperação entre as áreas envolvidas no PDP (MALTZ et al., 2001). Estes trabalhos resultaram na criação de diferentes metodologias que procuram aumentar a integração e a cooperação entre as áreas envolvidas no PDP.

Rozenfeld et al. (2006) destaca que quando diferentes áreas trabalham em conjunto na resolução de problemas do PDP, uma área dá suporte à outra, 
facilitando o encontro da solução, o que acaba resultando em ganho de tempo no desenvolvimento de novos produtos. Entretanto, para que isso ocorra é necessário que existam discussões entre os times, a comunicação deve ser intensa, bidirecional, precoce e intensiva. Isto não significa somente a existência de ética, união, criatividade e ausência de conflitos; a essência para a integração é que exista uma coordenação em tempo real entre as diferentes áreas envolvidas no PDP.

Tão é importante a integração interfuncional para o PDP, que as empresas estão estruturando o processo em fases, utilizando times multidisciplinares e incorporando métodos e técnicas de suporte para execução das atividades de desenvolvimento de novos produtos, visando melhorar a utilização de uma linguagem comum entre as equipes envolvidas no PDP. Esses métodos e técnicas de suporte devem auxiliar na comunicação formal entre as diferentes áreas de conhecimento, pois o PDP é por natureza, baseado nos conhecimentos de áreas muito distantes (marketing, engenharia do produto e manufatura). Portanto, serão conceituados a seguir alguns métodos e técnicas de suporte utilizados no PDP.

\subsubsection{Utilização de métodos e técnicas de suporte ao PDP}

Neste tópico são abordados os métodos e técnicas mais utilizados no PDP, para auxiliar na condução das interfaces organizacionais e estruturar a gestão do projeto de processo no PDP, proporcionando um melhor desempenho no desenvolvimento e conseqüentemente um produto de qualidade.

A qualidade do produto desenvolvido é um dos critérios exigidos para se analisar o desempenho do PDP, pois esta variável está intimamente ligada ao mercado consumidor e ao mesmo tempo, ao projeto do processo (ROZENFELD et al., 2006). Outro critério essencial à análise de desempenho diz respeito ao tempo de desenvolvimento, ou seja, ao lead time do projeto, que acompanha tanto as freqüentes variações nas exigências dos clientes quanto á introdução de novas tecnologias, objetivando ser o primeiro em inovação (CLARK; FUJIMOTO, 1991).

Assim, pode-se notar que há um grande desafio no que diz respeito à melhor maneira de combinar os parâmetros qualidade, tempo e produtividade para se obter um PDP eficiente e eficaz. Com isso, sua gestão torna-se uma atividade complexa e o emprego de métodos e técnicas durante o desenvolvimento de novos produtos 
tem a finalidade de auxiliar o seu gerenciamento, objetivando um melhor desempenho no PDP.

São diversos os tipos de métodos e técnicas, e a maneira como cada um deles influência as atividades no PDP. Para Faesarella et al. (1996) a escolha do método a ser utilizado depende do tipo de projeto e de produto a ser desenvolvido e da estrutura organizacional da empresa que irá desenvolver os mesmos.

Segue os principais métodos e técnicas utilizadas na fase de projeto do processo no PDP e uma breve descrição de suas principais características:

a) O método de análise do tipo e efeito de falha, conhecida como Failure Mode and Effect Analysis (FMEA), é um método que busca aumentar a confiabilidade, por meio da análise das falhas potenciais e propostas de ações de melhorias, e procura evitar que ocorram falhas no projeto do produto ou do processo (PUENTE et al., 2002). Este método pode ser aplicado tanto no desenvolvimento do projeto do produto como do processo, sendo que as etapas e a maneira de realização da análise são as mesmas, diferenciando-se apenas quanto ao objetivo. As análises são classificadas em três tipos (STAMATIS, 2003): FMEA de sistema; FMEA de produto; e FMEA de processo. Vale destacar a importância do método por proporcionar para a empresa uma forma sistemática de se catalogar informações sobre as falhas dos produtos/processos, bem como, melhorar o conhecimento dos problemas, através de ações de melhoria baseado em dados devidamente monitoradas. Segundo Clausing (1994), por meio da prevenção de ocorrência de falhas se consegue reduzir os custos;

b) O Quality Function Deployment (QFD) é um método de conversão dos requisitos do cliente em características de qualidade do produto e o desenvolvimento da qualidade de projeto para o produto acabado, através de desdobramentos sistemáticos das relações entre os requisitos do consumidor e as características do produto (AKAO, 1990). Esses desdobramentos iniciam-se com cada mecanismo e se estendem para cada componente ou processo, e a qualidade global do produto será formada através desta rede de relações (KING, 1989). Os principais benefícios do QFD são (HAUSER; CLAUSING, 1988): reduzir o número de mudanças de projeto; diminuir o ciclo de projeto; reduzir os custos de início de operação; reduzir reclamações de garantia; planejar a garantia de qualidade mais estável; favorecer a comunicação entre os diferentes agentes que 
atuam no PDP; traduzir as vontades dos clientes; e identificar as características que mais contribuem para os atributos de qualidade;

c) O método de análise da árvore de falhas ou Fault Tree Analysis (FTA) é do tipo Top-down, cuja análise se inicia com um evento indesejável, como uma falha ou mau funcionamento, chamado evento de topo, a partir do qual devem ser determinadas todas as maneiras de ocorrência deste evento. Em outras palavras, após a identificação do evento de topo determinam-se como os eventos de níveis inferiores, individuais ou combinados causaram a falha do sistema. É uma importante técnica de análise de projeto de confiabilidade e segurança que parte da consideração dos efeitos de falha sobre o sistema, evento de topo, para chegar à causa que gerou o efeito (ROZENFELD et al., 2006);

d) O método de Análise de Valor ou Engenharia de Valor (AV/EV) é um esforço organizado para atingir o valor ótimo de um produto, sistema ou serviço, promovendo as funções necessárias ao menor custo, seu surgimento está ligado à pesquisa de novos materiais, de custo menor e de fácil obtenção, substituindo os materiais escassos (COLENCI JR, 1989). A análise de valor é utilizada para produtos já existentes, em fase de produção, enquanto a engenharia de valor é utilizada para projetos e produtos na fase de desenvolvimento. Este método é utilizado em todas as fases do ciclo do produto, e melhores resultados são obtidos quando o método é aplicado aos novos produtos já na fase inicial, onde os custos de mudanças implementadas são menores e o potencial dos resultados é bastante alto (BASSO, 1991). A sustentação deste método está consolidada basicamente em quatro áreas: especialização; criatividade; reconhecimento; e análise das funções. Segundo Basso (1991), o conteúdo base de qualquer aplicação do método de AV/EV envolve três etapas distintas, que são: estabelecimento das funções, avaliação da função por comparação e desenvolvimento de alternativas para o valor;

e) Os métodos de Design for Manufacturing (DFM) e Design for Assembly (DFA) visam aperfeiçoar o projeto ainda na fase de definição de processos e formas finais, buscando-se menores tempos e custos (BOOTHROYD et al., 1994). Esses dois métodos baseiam-se na experiência adquirida e buscam externalizar e sistematizar o conhecimento, com isso percebem-se a sua importância como mecanismos não só de auxílio técnico, mas, também, de apoio à gestão de conhecimento da empresa (FERRARI et al., 2001). 
Após uma rápida descrição sobre os principais métodos e técnicas de suporte ao PDP, a próxima seção trata da estrutura referencial que Clark e Wheelwright (1992) propuseram para que a alta gerência possa compreender melhor o PDP como um todo. Esta estrutura referencial é utilizada na investigação da parte empírica do presente trabalho, para entender como funciona o PDP dos casos analisados.

\subsubsection{Estrutura referencial para compreensão do PDP}

A estrutura referencial descrita a seguir é muito utilizada por pesquisadores como ponto de partida para investigação do PDP de empresas (VALERI, 2000). Considerando que para se obter sucesso no desempenho do PDP, faz-se necessário que as escolhas e tomadas de decisões sejam efetuadas de maneira organizada dentro de uma empresa.

De acordo com os autores Clark e Fujimoto (1991), Tatikonda e Rosenthal (2000), o PDP é considerado complexo em termos de natureza, quantidade e magnitude das atividades organizacionais e interações requeridas à execução do projeto. Assim sendo, Clark e Wheelwright (1992) propuseram uma estrutura referencial composta por seis dimensões para auxiliar na compreensão da complexidade deste processo pela alta administração, essas dimensões são referentes: a definição de projeto; a organização de projeto e de pessoal envolvido; a liderança e gerenciamento de projeto; a resolução de problemas, testes e protótipos; as revisões gerenciais e controle; e as alterações de projeto. Estas seis dimensões são indicadas na figura 12 e detalhadas em seguida.

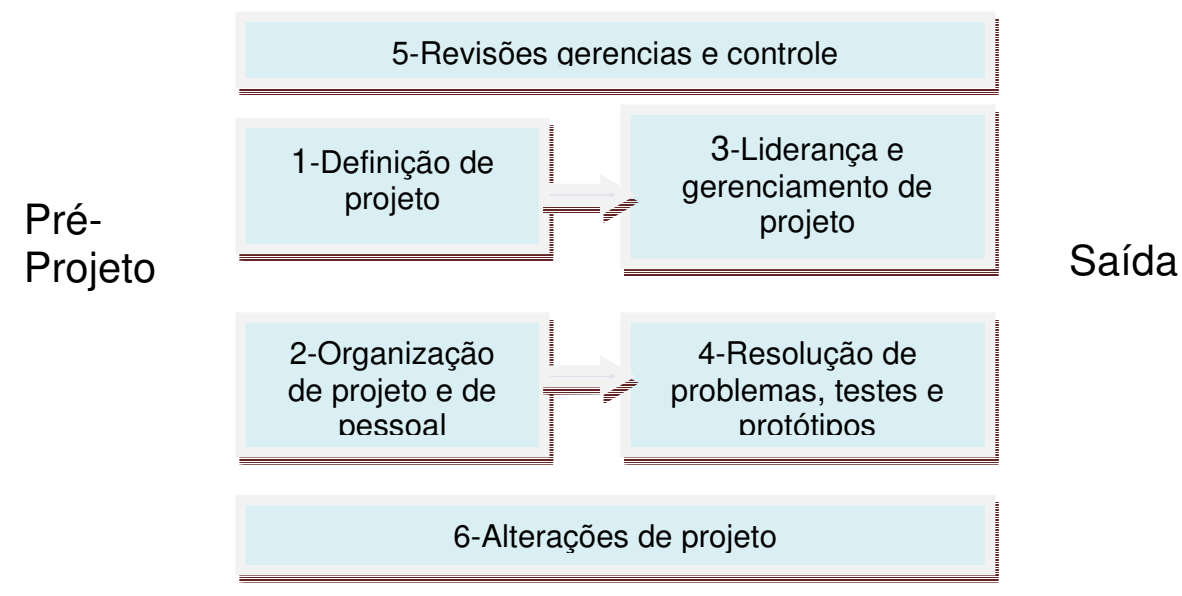

Figura 12 - Estrutura referencial para compreensão do PDP.

Fonte: Clark e Wheelwright (1992). 
1. A definição do projeto: esta dimensão define a configuração do escopo do projeto a ser desenvolvido, determinando os principais parâmetros do desenvolvimento e suas respectivas interfaces com a empresa, e por fim definindo os objetivos do projeto;

2. A organização do projeto e de pessoal envolvido: esta dimensão aborda as pessoas de diferentes áreas envolvidas no desenvolvimento e a forma de estruturação das equipes, também são levantadas as questões de localização, relações hierárquicas e departamentais, responsabilidades e práticas de treinamento;

3. A liderança e gerenciamento do projeto: esta dimensão detalha o papel dos líderes de desenvolvimento e a condução do projeto, ou seja, como as fases do desenvolvimento são estruturadas;

4. A resolução de problemas, testes e protótipos: esta dimensão engloba os problemas interfuncionais no desenvolvimento, sejam de caráter gerencial ou técnico e a forma como são conduzidos os testes, além de tratar as atividades pendentes do projeto;

5. As revisões gerenciais e controle: esta dimensão cuida da integração da alta administração com o time de desenvolvimento, detalhando como a alta gerência revisa e avalia o projeto em andamento, e utiliza da prática de motivação no decorrer do desenvolvimento do projeto;

6. As alterações de projeto: esta dimensão destaca os indicadores de desempenho e medição do desenvolvimento do projeto, além de práticas de redirecionamento das atividades para solução de problemas e o lançamento mais rápido do produto.

A estrutura de Clark e Wheelwright (1992) proporciona à alta gerência um maior entendimento do PDP, dando mais subsídios para a tomada de decisão e solução de problemas de caráter gerencial ou técnico. Estas seis dimensões também auxiliam na redução do impacto da complexidade, seja por parte do produto ou do processo no PDP.

Esta seção sobre a estrutura referencial para compreensão do PDP encerra a etapa de varredura horizontal. Após ter uma visão geral sobre os principais tópicos relevantes ao tema PDP, a pesquisa parte para a próxima etapa da revisão bibliográfica, que é a varredura vertical, abordando as variáveis da fase de projeto do processo no PDP. 


\section{$2.2 \quad$ Varredura vertical}

Com o direcionamento do trabalho definido, partiu-se para uma varredura vertical na literatura, afunilando o conceito de PDP para fase do projeto de processo, através da consulta de artigos relacionados a esta fase do PDP. Nesta revisão da literatura foram consultados 126 trabalhos de diferentes fontes, e foram selecionados 55 deles mais diretamente relacionados ao projeto do processo. Dentro desses estudos analisados constatou-se que a abordagem metodológica de pesquisa utilizada foi 0 estudo de caso (40\%), seguido por levantamento tipo survey (32,5\%), trabalhos teórico-conceitual (15\%) e revisões da literatura (12,5\%). A abordagem dos estudos, segundo a sua natureza divide-se em qualitativa $(48,3 \%)$ e quantitativa $(51,7 \%)$, no qual utilizaram como principal instrumento de coleta de dados a entrevista $(50,0 \%)$ e o questionário $(28,6 \%)$, e $(21,4 \%)$ utilizam ambos os instrumentos de coleta. A tabela 7 sintetiza as principais abordagens metodológicas encontradas na varredura vertical.

Tabela 7 - Principais abordagens metodológicas encontradas na varredura vertical relacionados ao projeto do processo.

\begin{tabular}{l|c|l|c|l|c}
\hline $\begin{array}{c}\text { METODOLOGIA DE } \\
\text { PESQUISA }\end{array}$ & $\%$ & $\begin{array}{c}\text { NATUREZA DOS } \\
\text { DADOS }\end{array}$ & $\%$ & $\begin{array}{c}\text { INSTRUMENTO DE COLETA } \\
\text { DE DADOS }\end{array}$ & $\%$ \\
\hline Estudo de Caso & 40,0 & Qualitativa & 48,3 & Entrevista & 50,0 \\
\hline Survey & 32,5 & Quantitativa & 51,7 & Questionário & 28,6 \\
\hline Teórico Conceitual & 15,0 & & & Entrevista + Questionário & 21,4 \\
\cline { 1 - 1 } & & & \multicolumn{2}{|c}{} \\
\hline Revisão da Literatura & 12,5 & & &
\end{tabular}

Fonte: Elaborado pelo autor.

Nesta etapa da revisão da literatura, conseguiu-se identificar a importância das principais variáveis do PDP com a fase de projeto do processo, citada por diversos autores que pesquisaram o assunto, mostrados na tabela 8.

Para dar embasamento ao referencial teórico desta pesquisa, que busca fazer uma análise de caráter descritivo da natureza do relacionamento entre as variáveis, apesar de existir uma tentativa de buscar a causalidade entre as variáveis da fase de projeto do processo. As variáveis encontradas nesta varredura foram analisadas de acordo com a especificidade de cada uma, e selecionadas pela importância relacionada às questões de pesquisa propostas no início do trabalho, para serem abordadas nesta etapa da revisão bibliográfica. 
Tabela 8 - Variáveis encontradas na varredura vertical relacionadas a fase de projeto do processo.

\begin{tabular}{|c|c|c|c|}
\hline $\begin{array}{l}\text { PRINCIPAIS } \\
\text { VARIÁVEIS }\end{array}$ & REFERÊNCIAS SELECIONADAS & $\begin{array}{l}\text { PRINCIPAIS } \\
\text { VARIÁVEIS }\end{array}$ & REFERÊNCIAS SELECIONADAS \\
\hline $\begin{array}{l}\text { Ambiente de } \\
\text { incerteza }\end{array}$ & $\begin{array}{l}\text { Kenny, J. (2003); Van Oorschot, K. } \\
\text { E. et al. (2005); Bstieler, L.; Gross, C. } \\
\text { W. (2003) }\end{array}$ & Integração & $\begin{array}{l}\text { Abdomerovic, M.; Blakemore, G. } \\
\text { (2002); Amaral, D. C. (2002); Freitas, } \\
\text { C. (2004); Krishnan, V.; Loch, C. H. } \\
\text { (2005); Cheng, L. C. (2000); Haque, B. } \\
\text { et al. (2003); Altamirano, A. V. (1999); } \\
\text { Tatikonda, M. V.; Montoya-Weiss, M. } \\
\text { M. (2001); Maltz, E. et al. (2001) }\end{array}$ \\
\hline $\begin{array}{l}\text { Aprendizagem } \\
\text { do time }\end{array}$ & $\begin{array}{l}\text { Akgun, A. E. et al. (2006); Muldin, A. } \\
\text { et al. (2002); Rozenfeld, H. et al. } \\
\text { (2006) }\end{array}$ & $\begin{array}{l}\text { Interação das } \\
\text { variáveis de } \\
\text { processo }\end{array}$ & $\begin{array}{l}\text { Abdomerovic, M.; Blakemore, G. } \\
\text { (2002); Maltz, E. et al. (2001) }\end{array}$ \\
\hline $\begin{array}{l}\text { Colaboração e } \\
\text { comunicação }\end{array}$ & $\begin{array}{l}\text { Nambisan, S. (2003); Nobelius, D. } \\
\text { (2004); Haque, B. et al. (2003); } \\
\text { Cormican, K., O'sullivan, D. (2004) }\end{array}$ & $\begin{array}{l}\text { Mecanismo de } \\
\text { controle da alta } \\
\text { gerência }\end{array}$ & $\begin{array}{l}\text { Bonner, J. M. et al. (2002); Lester, D. } \\
\text { H. (1998); Rozenfeld, H. et al. (2006) }\end{array}$ \\
\hline $\begin{array}{l}\text { Cumprimento de } \\
\text { prazos }\end{array}$ & $\begin{array}{l}\text { Syamil, A. et al. (2004); Kenny, J. } \\
\text { (2003); Prancic, E.; Martins, R. A. } \\
\text { (2003); Driva, H. et al. (2000) }\end{array}$ & $\begin{array}{l}\text { Melhoria } \\
\text { contínua e } \\
\text { performance }\end{array}$ & $\begin{array}{l}\text { Dooley, K.; Johnson, D. (2001); } \\
\text { Nilsson-Witell, L. et al. (2005); Shane, } \\
\text { S. A.; Ulrich, K.T. (2004); Hart, S. et al. } \\
\text { (2003) }\end{array}$ \\
\hline $\begin{array}{l}\text { Definição de } \\
\text { responsabilidade }\end{array}$ & $\begin{array}{l}\text { Abdomerovic, M.; Blakemore, G. } \\
\text { (2002); Fredericks, E. (2005); } \\
\text { Rozenfeld, H. et al. (2006) }\end{array}$ & $\begin{array}{l}\text { Mudanças } \\
\text { organizacionais }\end{array}$ & $\begin{array}{l}\text { Chroneer, D.; Laurell-Stenlund, K. } \\
\text { (2001); Dooley, K.; Johnson, D. (2001); } \\
\text { Kenny, J. (2003) }\end{array}$ \\
\hline $\begin{array}{l}\text { Diretriz para } \\
\text { gerentes de } \\
\text { projeto }\end{array}$ & $\begin{array}{l}\text { Akgun, A. E. et al. (2006); Rozenfeld, } \\
\text { H. et al. (2006) }\end{array}$ & $\begin{array}{l}\text { Necessidade de } \\
\text { padrões claros } \\
\text { no PDP }\end{array}$ & $\begin{array}{l}\text { Abdomerovic, M.; Blakemore, G. } \\
\text { (2002); Haque, B. et al. (2003); } \\
\text { Rozenfeld, H. et al. (2006) }\end{array}$ \\
\hline Duração do ciclo & $\begin{array}{l}\text { Griffin, A. (1997); Rozenfeld, H. et al. } \\
(2006)\end{array}$ & $\begin{array}{l}\text { Planejamento de } \\
\text { processo no PDP }\end{array}$ & $\begin{array}{l}\text { Kenny, J. (2003); Syamil, A. et al. } \\
\text { (2004); Rozenfeld, H. et al. (2006) }\end{array}$ \\
\hline $\begin{array}{l}\text { Entender os } \\
\text { problemas das } \\
\text { áreas envolvidas }\end{array}$ & $\begin{array}{l}\text { Abdomerovic, M.; Blakemore, G. } \\
\text { (2002); Altamirano, A. V. (1999); } \\
\text { Tatikonda, M. V.; Montoya-Weiss, M. } \\
\text { M. (2001) }\end{array}$ & $\begin{array}{l}\text { Processos de } \\
\text { projeto e produto } \\
\text { complexos }\end{array}$ & $\begin{array}{l}\text { Estorilio, C. C. A. (2003); Kim, J.; } \\
\text { Wilemon, D. (2003); Griffin, A. (1997); } \\
\text { Cooper, R. G.; Kleinschmidt, E. J. } \\
\text { (2000); Tatikonda, M. V.; Rosenthal, S. } \\
\text { R. (2000) }\end{array}$ \\
\hline $\begin{array}{l}\text { Envolvimento da } \\
\text { alta gerência }\end{array}$ & $\begin{array}{l}\text { Bonner, J. M. (2002); Song, M.; Noh, } \\
\text { J. (2006) }\end{array}$ & \begin{tabular}{|l|} 
Product \\
development \\
business process
\end{tabular} & $\begin{array}{l}\text { Holmes, M. F.; Campbell, R. B. Jr. } \\
\text { (2002); Rozenfeld, H. (1996) }\end{array}$ \\
\hline Estratégia & $\begin{array}{l}\text { Shane, S. A.; Ulrich, K. T. (2004); } \\
\text { Griffin, A. (1997); Krishnan, V.; Loch, } \\
\text { C. H. (2005); Cheng, L. C. (2000); } \\
\text { Cormican, K., O'sullivan, D. (2004) }\end{array}$ & $\begin{array}{l}\text { Produtividade do } \\
\text { time }\end{array}$ & $\begin{array}{l}\text { Syamil, A. et al. (2004); Hultink, E. J.; } \\
\text { Robben, H. S. J. (1995); Prancic, E.; } \\
\text { Martins, R. A. (2003); Driva, H. et al. } \\
(2000)\end{array}$ \\
\hline $\begin{array}{l}\text { Evitar perda de } \\
\text { conhecimento }\end{array}$ & $\begin{array}{l}\text { Antoni, M. et al. (2005); Muldin, A. et } \\
\text { al. (2002) }\end{array}$ & $\begin{array}{l}\text { Sistema de } \\
\text { informação no } \\
\text { PDP }\end{array}$ & $\begin{array}{l}\text { Nambisan, S. (2003); Tonioli, J. N. } \\
\text { (2003); Cooper, R. G.; Kleinschmidt, E. } \\
\text { J. (2000) }\end{array}$ \\
\hline $\begin{array}{l}\text { Fatores de } \\
\text { sucesso }\end{array}$ & $\begin{array}{l}\text { Ozer, M. (2006); Huang, X. (2002); } \\
\text { Lester, D. H. (1998); Cooper, R. G.; } \\
\text { Kleinschmidt, E. J. (2000); Song, M.; } \\
\text { Noh, J. (2006); Cheng, L. C. (2000); } \\
\text { March-Chordà, I. et al. (2002); } \\
\text { Cormican, K., O'sullivan, D. (2004); } \\
\text { Cooper, R. G. (1993) }\end{array}$ & $\begin{array}{l}\text { Stage-Gate e } \\
\text { revisão de fases }\end{array}$ & $\begin{array}{l}\text { Valeri, S. G. (2000); Hart, S. et al. } \\
\text { (2003); O'connor, P. (1994); Lint, O.; } \\
\text { Pennings, E. (2001); Cooper, R. G. } \\
\text { (1993) }\end{array}$ \\
\hline $\begin{array}{l}\text { Gerenciamento } \\
\text { de projetos }\end{array}$ & $\begin{array}{l}\text { Kenny, J. (2003); Thieme, R. J. et al. } \\
\text { (2003); Valeri, S. G. (2000) } \\
\text { Van Oorschot, K. E. et al. (2005); } \\
\text { Huang, X. (2002); Nambisan, S. } \\
\text { (2003); Lester, D. H. (1998); Tonioli, } \\
\text { J. N. (2003); Cooper, R. G.; } \\
\text { Kleinschmidt, E. J. (2000); Song, M.; } \\
\text { Noh, J. (2006) }\end{array}$ & $\begin{array}{l}\text { Times } \\
\text { multifuncionais }\end{array}$ & $\begin{array}{l}\text { Fredericks, E. (2005); Bonner, J. M. et } \\
\text { al. (2002); Griffin, A. (1997); Song, M.; } \\
\text { Noh, J. (2006); Nobelius, D. (2004); } \\
\text { Haque, B. et al. (2003); Sousa Mendes, } \\
\text { G H.; Toledo, J. C. (2003) }\end{array}$ \\
\hline
\end{tabular}

Fonte: Elaborado pelo autor. 
Tabela 8 - Variáveis encontradas na varredura vertical relacionadas a fase de projeto do processo Continuação.

\begin{tabular}{|c|c|c|c|}
\hline $\begin{array}{l}\text { PRINCIPAIS } \\
\text { VARIÁVEIS }\end{array}$ & REFERÊNCIAS SELECIONADAS & $\begin{array}{l}\text { PRINCIPAIS } \\
\text { VARIÁVEIS }\end{array}$ & REFERÊNCIAS SELECIONADAS \\
\hline Gestão & $\begin{array}{l}\text { Da Silva, M. M; Alliprandini, D. } \\
\text { H.(2000); Cheng, L. C. (2000); } \\
\text { Haque, B. et al. (2003) }\end{array}$ & $\begin{array}{l}\text { Tomada de } \\
\text { decisão }\end{array}$ & $\begin{array}{l}\text { Shane, S. A.; Ulrich, K. T. (2004); Hart, } \\
\text { S. et al. (2003); Lint, .; Pennings, E. } \\
\text { (2001); Krishnan, V.; Ulrich, K. T. } \\
\text { (2001); Cooper, R. G.; Kleinschmidt, E. } \\
\text { J. (2000) }\end{array}$ \\
\hline $\begin{array}{l}\text { Indicadores de } \\
\text { desempenho }\end{array}$ & $\begin{array}{l}\text { Freitas, C. (2004); Silva, S. L. (2002); } \\
\text { Griffin, A. Page, A. L. (1993); Hultink, } \\
\text { E. J.; Robben, H. S. J. (1995); } \\
\text { Prancic, E.; Martins, R. A. (2003); } \\
\text { Driva, H. et al. (2000) }\end{array}$ & $\begin{array}{l}\text { Trabalho de } \\
\text { equipe no PDP }\end{array}$ & $\begin{array}{l}\text { Syamil, A. et al. (2004); Cheng, L. C. } \\
\text { (2000); Haque, B. et al. (2003); Sousa } \\
\text { Mendes, G H.; Toledo, J. C. (2003) }\end{array}$ \\
\hline $\begin{array}{l}\text { Inovação } \\
\text { tecnológica }\end{array}$ & $\begin{array}{l}\text { Shane, S. A.; Ulrich, K. T. (2004); } \\
\text { Lager, T. (2002); Krishnan, V.; Loch, } \\
\text { C. H. (2005); Nobelius, D. (2004); } \\
\text { Cormican, K., O'sullivan, D. (2004) }\end{array}$ & $\begin{array}{l}\text { Utilização de } \\
\text { ferramentas } \\
\text { estatísticas }\end{array}$ & $\begin{array}{l}\text { Thia, C. W. et al. (2005); Larsen, M.; } \\
\text { Kim, J. (2001) }\end{array}$ \\
\hline
\end{tabular}

Fonte: Elaborado pelo autor.

A seguir é realizada uma definição básica de cada variável, baseado no conceito utilizado por diversos autores da literatura, para que se possa ter um entendimento inicial dos mesmos e sua importância com o a fase de projeto do processo no PDP:

- Ambiente de incerteza: é o desafio de gerenciar as incertezas envolvidas no processo, onde as decisões de maior impacto têm que ser tomadas no momento em que existe maior grau de incerteza;

- Aprendizagem do time: a aprendizagem se dá principalmente pela troca de informações obtidas por meio da experiência no desenvolvimento, e o mais importante é não se esquecer de documentá-las;

- Colaboração e comunicação: a comunicação refere-se à troca de informações, isso vale para os tipos verbais e escritos. A colaboração diferencia-se da comunicação devido ao foco em aspectos como trabalho em grupo, compartilhamento de recursos, confiança mútua, e objetivo e visão comuns, ou seja, aspectos mais informais e subjetivos;

- Cumprimento de prazos: cumprir os prazos pré-estabelecidos para que não ocorra atraso e aumento de custo do projeto e demora no lançamento do novo produto no mercado;

- Definição de responsabilidades: definir os times e especialistas responsáveis pela condução do projeto, definindo seus papéis, contribuição de cada um e suas responsabilidades; 
- Diretriz para gerentes de projeto: os gerentes de projeto devem melhorar 0 desempenho do time, resolver conflitos, isolar os times de problemas exteriores, e prover recursos, deve também propor um bom ambiente de trabalho e ter uma visão ampla sobre o caminho a ser trilhado pelo time;

- Duração do ciclo de desenvolvimento de produtos: para que se tenha um melhor controle do projeto e se crie interdependência entre as atividades, dividem-se os projetos em algumas fases, constituindo o chamado ciclo de vida do projeto, que define quais técnicas de trabalho serão utilizadas e quais pessoas estarão envolvidas em cada fase;

- Entender os problemas das áreas envolvidas: através da integração buscar entender as limitações e variáveis de processo envolvidas no desenvolvimento do produto;

- Envolvimento da alta gerência: é importante para administrar a integração do time do projeto, revisar e avaliar os projetos e suas metas, criar motivações e incentivos durante o curso do projeto, e o mais importante tomarem decisões nos momentos de incerteza;

- Estratégia: agrega dois mecanismos, o desenvolvimento de objetivos e metas, no qual a empresa traduz sua estratégia empresarial em exigências específicas para organização do desenvolvimento em termos de desempenho, como lead time, produtividade, e número de novos produtos criados; e o plano de projeto agregado, que determina o mix específico para tipos de projetos que se ajusta a estratégia empresarial, e afere sua capacidade para empreender aqueles projetos, além de definir o grupo apropriado de projetos dado suas oportunidades e restrições;

- Evitar perda de conhecimento: evitar perda de informações tecnológicas obtidas por meio da experiência seja fazendo testes operando processos produtivos ou desenvolvendo produtos na área para aprender com eles. Pois durante o projeto do processo são tomadas várias decisões que devem ser documentadas, para que não se incorram em erros semelhantes aos ocorridos no passado;

- Fatores de sucesso: o produto deve ser diferenciado proporcionando benefícios ao cliente; ter orientação para um mercado atrativo; dedicar mais tempo à fase de pré-desenvolvimento; definir bem o produto e seus conceitos; 
ter velocidade para lançar o novo produto; e as companhias que tem o desenvolvimento de produto estruturado em fases têm melhor desempenho;

- Gerenciamento de projetos: oferece uma visão integrada de todos os fatores envolvidos em um projeto para que sejam atingidos os objetivos assumidos, tendo um enfoque humanístico e participativo, orientado para a obtenção de resultados, com a premissa de que os resultados são atingidos por meio do trabalho de pessoas;

- Gestão: a gestão do projeto do processo é bem complexa, porém são muitas as vantagens competitivas que se obtém tendo esta fase bem estruturada e gerenciada, entre elas: melhor qualidade do produto, tempo de lançamento no mercado e manufaturabilidade;

- Indicadores de desempenho: os indicadores de desempenho utilizados no projeto do processo estão estruturados de forma a garantir uma associação imediata com problemas críticos, e deve permitir uma comparação com resultados de outros projetos da empresa e de concorrentes, e também com os objetivos e metas estabelecidos, visando o desdobramento de ações de melhoria e solução de problemas;

- Inovação tecnológica: o processo de inovação consiste em sua essência, na busca, descoberta, experimentação, desenvolvimento e adoção de novos produtos ou novos processos produtivos;

- Integração: integrar é obter uma operação mais eficaz dos processos de negócio de uma empresa e entre eles, compreendendo as pessoas, máquinas e informação, de acordo com os objetivos da empresa;

- Interação das variáveis de processo: consiste em ter uma visão comum de todas as atividades do processo e suas variáveis, e compartilhar informações e recursos para obter melhores resultados;

- Mecanismo de controle da alta gerência: a alta gerência pode utilizar de indicadores de desempenho para acompanhar os resultados do desenvolvimento, além de estruturas referenciais que auxiliam na compreensão do processo;

- Melhoria contínua e performance no PDP: toda mudança é uma oportunidade de melhoria e aprendizado, a metodologia de gerenciamento de melhoria mais utilizada é baseada no ciclo planejar, executar, verificar e agir corretivamente, mais conhecido como PDCA; 
- Mudanças organizacionais: a mudança organização das atividades no projeto do processo se refere à forma como os indivíduos estão ligados, individualmente ou em grupos, seja formal ou informalmente. As mudanças ocorrem na forma de realizar essa ligação organizacional, seja por meio do alinhamento de funções ou de projetos;

- Necessidade de padrões claros: a padronização é o estabelecimento de regras comuns e procedimentos que se aplicam uniformemente a todos, em quase todas as situações;

- Planejamento de processo: incluem informações sobre as possibilidades técnicas e os requisitos de produção, consideram-se neste planejamento os investimentos necessários e a viabilidade econômica;

- Processos de projeto e produto complexos: diferentes combinações da complexidade do produto e do processo dão origem a diferentes aspectos no gerenciamento do desenvolvimento de produtos;

- Product Development Business Process (PDBP): foca o cliente final, integrando as diferentes pessoas e áreas funcionais envolvidas e busca uma simultaneidade na realização das tarefas, para integrar os processos do negócio da empresa;

- Produtividade do time: a produtividade do time está diretamente relacionada às condições fornecidas pelos gerentes de projeto e aos resultados conseguidos com o desenvolvimento;

- Sistema de informação: é utilizada como ferramenta de apoio, facilitando a manipulação dos dados para o emprego de técnicas e métodos disponíveis na área, sua principal vantagem é a velocidade de processamento e análise de dados, facilitando a geração de relatórios;

- Stage Gate e revisão de fases: processo sistemático para avaliação do final de fase de um projeto de desenvolvimento de produto. $O$ resultado final esperado é a aprovação do projeto, que indica qual time de desenvolvimento poderá dar continuidade a uma nova fase de desenvolvimento, seguindo o procedimento crítico da transição;

- Times multifuncionais: é composto por pessoas de diversas áreas (marketing, engenharia do produto e manufatura), para exatamente poder unir as suas diferentes habilidades; 
- Tomada de decisão: o desenvolvimento de produtos envolve um grande número de decisões num ambiente de alta incerteza, devido a sua natureza complexa, muitas decisões são afetadas por estágios anteriores e também por estágios futuros, causando problemas de custo, tempo e qualidade;

- Trabalho de equipe: ao longo do projeto do processo é importante que se busque o trabalho em equipe, de forma que as partes envolvidas percebam que suas contribuições individuais se encaixam em um todo maior, dado pelo esforço conjunto da equipe;

- Utilização de ferramentas estatísticas: a utilização de ferramentas permite que ocorra interação e servem de suporte na condução do desenvolvimento, considerando que sua escolha depende do tipo de produto e processo a ser desenvolvido e da estruturação da empresa.

As variáveis encontradas nesta busca foram analisadas de acordo com a especificidade de cada uma, e selecionadas pela importância relacionada às questões de pesquisa do trabalho. Na verdade, os conceitos e importância destas variáveis da literatura sobre o PDP, se inter-relacionam e se agrupam nos quatro macros tópicos do PDP (estratégico; organizacional; atividades/informações; e recursos). Estas variáveis selecionadas se complementam buscando aprimorar a estrutura de gestão do PDP. No entanto, devido as 32 variáveis de destaque na literatura, tabela 8, resultar em uma quantidade elevada para ser analisada, é tratado neste trabalho apenas os mais relevantes para a fase de projeto do processo do segmento de aços planos do setor siderúrgico brasileiro, que são destacadas mais a frente.

Finalizada a etapa de sustentação teórica do trabalho, busca-se no próximo capítulo caracterizar as empresas do setor siderúrgico brasileiro, detalhando o parque industrial, os principais processos e produtos fabricados, e como ocorre a competitividade e a dinâmica tecnológica deste setor e demonstrar a sua importância como unidade de análise para este trabalho de pesquisa. 


\section{SETOR SIDERÚRGICO BRASILEIRO}

Este capítulo traz uma visão geral do setor siderúrgico brasileiro, buscando abordar suas principais características através do detalhamento do seu parque industrial, dos principais processos e produtos fabricados, da competitividade e da dinâmica tecnológica deste setor. O objetivo dessa descrição é caracterizar a complexidade operacional e a importância do PDP para este setor, e fornecer subsídios para justificar a escolha de duas plantas do segmento de aços planos do setor siderúrgico brasileiro como unidades de análise para este trabalho.

A caracterização do setor siderúrgico foi embasada na literatura, com informações disponibilizadas por entidades patronais, sites ${ }^{12}$ e periódicos especializados e jornais de circulação nacional. Apesar de, o presente trabalho contemplar duas unidades do segmento de aços planos do setor siderúrgico brasileiro é realizado uma breve descrição das tendências da siderurgia mundial, que está passando por um período de transformação, que consiste nos seguintes pontos (USIMINAS, 2006): desconstrução, deslocamento de produção, influência da China, pressão ambiental, e consolidação.

- Desconstrução: se caracteriza pela desativação de linhas obsoletas e áreas de Redução, eliminação de equipamentos poluidores principalmente na Europa, redução de capacidades ociosas, aquisição de ativos em países com baixos custos de produção, e fabricação ou compra de placas em países em desenvolvimento;

- Deslocamento de produção: percebe-se que a produção está migrando para países emergentes, formando dois blocos no setor, o bloco do Atlântico e o bloco do Pacífico;

- Influência da China: este país será responsável por 70\% do crescimento da produção mundial de aço até 2010 , representando $35 \%$ da produção mundial, além disso, a China está passando da característica de importador para exportador;

\footnotetext{
${ }^{12}$ Os principais sites consultados foram: Instituto Brasileiro de Siderurgia (IBS) - www.ibs.org.br; Associação Brasileira de Metalurgia e Materiais (ABM) - www.abmbrasil.com.br; Instituto Nacional dos Distribuidores de Aço (INDA) - www.inda.com.br. Além destes sites, foi consultado o banco de dados no sistema "intranet" das unidades de análise que disponibilizam periódicos, movimentos estratégicos do setor, mercado e produtos de aço, informações bibliográficas e atualidades técnicas siderúrgicas.
} 
- Pressão ambiental: aprofundamento das exigências ambientais, elevando os custos de projeto em até $40 \%$ do valor;

- Consolidação: a siderurgia mundial é fragmentada, mas vem se consolidando passando dos $18 \%$ da produção distribuídos entre as dez maiores empresas do setor em 1986 para 27\% em 2005, e considerando a liquidez e baixa dívida do setor há condições financeiras para se consolidar ainda mais, e também existem constantes notícias sobre aquisição e fusão.

\subsection{A história da siderurgia no Brasil}

A história da siderurgia no Brasil pode ser dividida em duas partes distintas, a primeira iniciada com forjas catalãs primitivas e a segunda com a implantação de altos fornos a carvão vegetal. Em 1973, foi inaugurada, no país, a primeira usina integrada produtora de aço que utilizava o processo de redução direta de minérios de ferro a base de gás natural, a Usina Siderúrgica da Bahia (USIBA). No mesmo ano foi criada a Siderurgia Brasileira S.A (SIDERBRAS). Dez anos depois, entrou em operação, em Vitória-ES, a Companhia Siderúrgica de Tubarão (CST). Em 1986, foi a vez da empresa Aços Minas Gerais (AÇOMINAS) começar a operação em Ouro Branco-MG (GOMES, 1983).

$\mathrm{Na}$ década de 80 , o mercado interno estava em retração e a alternativa era voltar-se para o exterior. De uma hora para outra, o Brasil passava de grande importador a exportador de aço, sem ter tradição no ramo. Mas a crise que atingia a siderurgia brasileira tinha amplitude mundial. Por toda parte, os mercados se

fechavam com medidas restritivas às importações. Na época, começaram a freqüentar as páginas dos jornais termos como restrições voluntárias, sobretaxas antidumping, direitos compensatórios e salvaguardas (IBS, 2007).

Na década de 90, a reestruturação setorial se deu pela privatização da siderurgia brasileira. As mudanças em sua configuração patrimonial, direta ou indiretamente vinculada às desestatizações, são parte de um amplo conjunto de transformações que incluiu também ajustes organizacionais, recuperação da situação financeira, retomada dos investimentos e redefinição da inserção internacional e de suas estratégias (PINHO, 2001). Se, em um primeiro momento, a reestruturação se limitou a mudanças organizacionais na gestão da empresa e da produção, 
posteriormente aprofundou-se de acordo com as estratégias das diferentes empresas.

Conforme Oliveira (2004) as principais mudanças estratégicas nas siderúrgicas brasileiras compreenderam: expansão horizontal pela via de aquisições; internacionalização ativa; redistribuição e especialização das linhas de produto entre usinas, com ou sem fechamento de plantas siderúrgicas; focalização no core business; e diversificação setorial.

\subsection{Parque siderúrgico do Brasil}

Nos primeiros anos da década de 90, era visível o esgotamento do modelo com forte presença do Estado na economia. Em 1991, começou o processo de privatização das siderúrgicas. Dois anos depois, em 1993, oito empresas estatais, com capacidade para produzir 19,5 milhões de toneladas (70\% da produção nacional), tinham sido privatizadas. As siderúrgicas deram prioridade aos investimentos em modernização e atualização tecnológica das usinas (PINHO, 2001), chegando ao ano de 2005 com uma produção de 31,6 milhões de toneladas de aço bruto, e no ano de 2006 houve uma redução de 2,2\% para 30,9 milhões de toneladas, conforme mostra a tabela 9.

Tabela 9 - Produção siderúrgica brasileira por tipo de produto.

Unid. $10^{3} \mathrm{t}$

\begin{tabular}{l|c|c|c|c|c}
\hline \multicolumn{1}{c|}{ PRODUÇÃO } & $\mathbf{2 0 0 2}$ & $\mathbf{2 0 0 3}$ & $\mathbf{2 0 0 4}$ & $\mathbf{2 0 0 5}$ & $\mathbf{2 0 0 6}$ \\
\hline \hline Aço Bruto & $\mathbf{2 9 . 6 0 4}$ & $\mathbf{3 1 . 1 4 7}$ & $\mathbf{3 2 . 9 0 9}$ & $\mathbf{3 1 . 6 1 0}$ & $\mathbf{3 0 . 9 0 1}$ \\
\hline Laminados & $\mathbf{1 9 . 0 3 2}$ & $\mathbf{2 1 . 0 9 0}$ & $\mathbf{2 3 . 3 6 8}$ & $\mathbf{2 2 . 6 0 7}$ & $\mathbf{2 3 . 5 0 4}$ \\
\hline Planos & 11.408 & 13.202 & 14.441 & 14.187 & 14.454 \\
\hline Longos & 7.624 & 7.888 & 8.927 & 8.420 & 9.050 \\
\hline Semi-Acabados p/Vendas & $\mathbf{8 . 8 4 1}$ & $\mathbf{8 . 0 2 9}$ & $\mathbf{7 . 1 8 7}$ & $\mathbf{6 . 6 2 9}$ & $\mathbf{6 . 3 4 7}$ \\
\hline Placas & 6.883 & 5.352 & 4.737 & 4.186 & 4.095 \\
\hline Lingotes, Blocos e Tarugos & 1.958 & 2.677 & 2.450 & 2.443 & 2.252 \\
\hline Ferro-Gusa & $\mathbf{2 9 . 6 9 4}$ & $\mathbf{3 2 . 0 3 9}$ & $\mathbf{3 4 . 5 5 8}$ & $\mathbf{3 3 . 8 8 4}$ & $\mathbf{3 2 . 4 5 2}$ \\
\hline Usinas Integradas & 23.139 & 24.170 & 24.901 & 24.110 & 22.985 \\
\hline Produtores Independentes & 6.555 & 7.869 & 9.657 & 9.774 & 9.467 \\
\hline Ferro-Esponja & $\mathbf{3 6 1}$ & $\mathbf{4 1 0}$ & $\mathbf{4 4 0}$ & $\mathbf{4 1 1}$ & $\mathbf{3 7 6}$ \\
\hline Fon-: IBS (2007) & & & & &
\end{tabular}

Fonte: IBS (2007).

Atualmente, o parque produtor de aço brasileiro, um dos mais modernos do mundo, está apto a entregar ao mercado qualquer tipo de produto siderúrgico, desde 
que sua produção se justifique economicamente (IBS, 2007). O parque está constituído de 25 usinas, sendo 11 integradas (produção a partir de minério de ferro) e 14 semi-integradas (produção a partir do ferro gusa com sucata), sendo que essas usinas siderúrgicas são: 1-Arcelor Mittal Inox Brasil; 2-Arcelor Mittal Cariacica - Aços Longos; 3-Arcelor Mittal Juiz de Fora - Aços Longos; 4-Arcelor Mittal Piracicaba Aços Longos; 5-Arcelor Mittal Monlevade - Aços Longos; 6-Arcelor Mittal Itaúna Aços Longos; 7-Arcelor Mittal Tubarão - Aços Planos; 8-Aços Villares; 9-Companhia Siderúrgica Nacional (CSN); 10-Companhia Siderúrgica Paulista (COSIPA); 11Gerdau Açominas - Ouro Branco; 12-Gerdau Açonorte; 13-Gerdau Aços Especiais Piratini; 14-Gerdau Barão de Cocais; 15-Gerdau Cearense; 16-Gerdau Cosigua; 17Gerdau Divinópolis; 18-Gerdau Guaíra; 19-Gerdau Riograndense; 20-Gerdau São Paulo; 21-Gerdau Usiba; 22-Siderúrgica Barra Mansa; 23-Usinas Siderúrgicas de Minas Gerais (USIMINAS); 24-V\&M do Brasil; e 25-Villares Metals.

Essas usinas são administradas por sete grupos empresariais, que são denominados: 1-Arcelor Mittal Brasil, Arcelor Mittal Inox Brasil (antiga Acesita), Arcelor Mittal Aços Longos (antiga Belgo), Arcelor Mittal Tubarão; 2-Grupo Gerdau ( Gerdau e Aços Villares); 3-CSN; 4-Usiminas/Cosipa; 5-Siderúrgica Barra Mansa; 6V\&M do Brasil; e 7-Villares Metals. A tabela 10 mostra as principais empresas e suas respectivas produções.

Tabela 10 - Produção de aço bruto por empresa no Brasil.

\begin{tabular}{l|c|c|c}
\multicolumn{1}{c|}{ EMPRESA } & $\mathbf{2 0 0 4}$ & $\mathbf{2 0 0 5}$ & Unid.10 $\mathrm{t}$ \\
\hline \hline Acesita & 835 & 753 & 810 \\
\hline Aços Villares & 816 & 680 & 704 \\
\hline Barra Mansa & 564 & 579 & 638 \\
\hline Belgo-Arcelor Brasil & 3.250 & 3.272 & 3.569 \\
\hline CSN & 5.518 & 5.201 & 3.499 \\
\hline CST-Arcelor Brasil & 4.958 & 4.850 & 5.136 \\
\hline Gerdau & 7.284 & 6.889 & 6.994 \\
\hline Usiminas-Cosipa & 8.951 & 8.661 & 8.770 \\
\hline V \& M do Brasil & 611 & 592 & 659 \\
\hline Villares Metals & 122 & 133 & 122 \\
\hline TOTAL & $\mathbf{3 2 . 9 0 9}$ & $\mathbf{3 1 . 6 1 0}$ & $\mathbf{3 0 . 9 0 1}$
\end{tabular}

Fonte: IBS (2007). 
Em função dos produtos que preponderam em suas linhas de produção, as usinas podem ser assim classificadas em (MOURÃO, 2007): semi-acabados (placas, blocos e tarugos); planos aços carbono (chapas e bobinas); planos aços especiais / ligados (chapas e bobinas); longos aços carbono (barras, perfis, fio máquina, vergalhões, arames e tubos sem costura); e longos aços especiais / ligados (barras, fio-máquina, arames e tubos sem costura).

No segmento de laminados comuns, a Gerdau Açominas e a Arcelor Mittal Brasil detêm conjuntamente cerca de $90 \%$ da capacidade de produção. No segmento de aços especiais, são quatro os produtores de aços longos (Aços Villares, Villares Metals, V\&M do Brasil e Gerdau-Açominas). No segmento de longos especiais (exceto tubos), a Aços Villares e Gerdau Aços Especiais Piratini são os únicos produtores brasileiros de aços para construção mecânica.

Existem também várias situações em que as empresas não enfrentam qualquer concorrência interna. A Aços Villares, ademais da produção de aços para construção mecânica, é a única fabricante no país de cilindros para laminação de aços em chapas, barras e perfis; enquanto a Villares Metals é o único fabricante nacional focado no segmento de aços especiais de alta liga. No caso dos planos especiais, a Arcelor Mittal Inox Brasil (antiga Acesita) desfruta de posição privilegiada, ao monopolizar a produção de laminados planos inoxidáveis e siliciosos. Por outro lado, a V\&M do Brasil detém o virtual monopólio do produto tubos de aço sem costura, com aproximadamente $95 \%$ da produção.

É fato que a concorrência é maior no segmento de aços planos comuns, unidade de análise do presente trabalho, devido a sua representatividade em termos financeiros e de produção ${ }^{13}$ em que atualmente USIMINAS-COSIPA, CSN e CSTArcelor Brasil dividem o mercado de laminados. A CST, de toda forma, atua somente em laminados a quente. Por outro lado, a CSN, no mercado de folhas-de-flandres, e a USIMINAS-COSIPA em certas classes de chapas, não enfrentam concorrentes internos. A tabela 11 a seguir ilustra a produção de laminados planos das empresas no Brasil.

${ }^{13}$ A produção do segmento de aços planos representou em 2006 (65\%) do total da produção de laminados no Brasil. 
Tabela 11 - Produção de laminados planos por empresa no Brasil.

\begin{tabular}{l|c|c}
\multicolumn{1}{c}{ EMPRESA } & $\mathbf{2 0 0 5}$ & Unid. $10^{3} \mathrm{t}$ \\
\hline \hline Acesita & 666 & $\mathbf{2 0 0 6}$ \\
\hline CSN & 4.534 & 706 \\
\hline CST-Arcelor Brasil & 2.341 & 4.055 \\
\hline Usiminas-Cosipa & 6.647 & 2.709 \\
\hline Total & $\mathbf{1 4 . 1 8 7}$ & 6.985 \\
\hline
\end{tabular}

Fonte: IBS (2007).

A estrutura societária da siderurgia brasileira já é bastante internacionalizada. No segmento de aços especiais (planos e longos), observa-se o controle acionário e operacional de grupos siderúrgicos europeus. Constata-se não somente investimentos que remontam à década de 50 , caso da subsidiária V\&M do Brasil, mas também investimentos recentes (Usinor-Arcelor, Sidenor e Bölhler-Uddeholm).

No segmento de aços longos comuns, a Belgo-Mineira é controlada pela Arcelor Mittal Brasil, que exerce importante papel na direção estratégica de três siderúrgicas brasileiras: Belgo-Mineira, Acesita e CST. Assim, é o único grupo siderúrgico com participação em todos os segmentos de mercado, à exceção dos laminados longos especiais, produzindo uma linha completa de produtos siderúrgicos: aços planos inoxidáveis e siliciosos (Acesita); placas e laminados a quente (CST); laminados a frio e galvanizados (Vega do Sul) e laminados longos e trefilados (Belgo-Mineira). O grupo Gerdau, por sua vez, é controlado pela família homônima. Já a Siderúrgica Barra Mansa é totalmente controlada pelo grupo Votorantin.

Segundo o IBS (2007), a previsão de investimentos no setor de 2007 a 2012 é de US $\$ 17,2$ bilhões, com projeção de alcançar a capacidade instalada de 52,2 milhões de toneladas no final destes cinco anos. Esse novo ciclo de investimentos está voltado para o aumento da capacidade de produção, a fim de atender ao crescimento da demanda interna que deve ser de mais de um milhão de toneladas por ano neste período. Desta previsão de investimentos, 3,21\% serão destinados à modernização e automação de processos e pesquisa e desenvolvimento de novos produtos. Sendo que estes 3,21\% representam US\$ 551 milhões, dos quais US\$ 355 milhões $(2,07 \%)$ são referentes à aplicação em informática e automação, US\$ 128 milhões $(0,74 \%)$ à treinamento de pessoas e US\$ 68 milhões $(0,40 \%)$ à pesquisa e desenvolvimento. A perspectiva de investimento em P\&D é superior ao realizado no período de 1994 a 2006, que foi de (0,35\%). Além disso, grupos 
produtores do exterior estudam a possibilidade de investir na construção de novas usinas siderúrgicas no Brasil, sobretudo no Norte e no Nordeste, voltadas para a exportação de produtos semi-acabados.

No caso do presente trabalho, são utilizadas como unidade de análise duas empresas do segmento de aços planos, que se justificam devido à liderança neste segmento, detendo $52 \%$ do mercado interno e representando $48,3 \%$ da produção de laminados planos no Brasil em 2006. Além disso, em virtude da maior concorrência e constante necessidade de investimentos ${ }^{14}$ neste segmento do setor siderúrgico.

\subsection{Processo e produtos siderúrgicos}

Na siderurgia, utiliza-se de carvão mineral, e em alguns casos o carvão vegetal. O carvão exerce duplo papel na fabricação do aço: como combustível, permite alcançar altas temperaturas, cerca de $1.500^{\circ}$ Celsius, necessárias à fusão do minério; e como redutor, associa-se ao oxigênio que se desprende do minério com a alta temperatura, deixando livre o ferro, este processo de remoção do oxigênio do ferro para ligar-se ao carbono chama-se redução e ocorre dentro de um equipamento chamado alto forno (MOURÃO, 2007).

Antes de serem levados ao alto forno, o minério e o carvão são previamente preparados para melhoria do rendimento e economia do processo. $O$ minério é transformado em pelotas e o carvão é destilado, para obtenção do coque, dele se obtém ainda subprodutos carboquímicos (RIZZO, 2005). No processo de redução, o ferro se liquefaz e é chamado de ferro gusa. Impurezas como calcário e sílica, formam a escória, que é matéria-prima para a fabricação de cimento.

A etapa seguinte é o refino, no qual o ferro gusa é levado para a aciaria, ainda em estado líquido, para ser transformado em aço mediante queima de impurezas e adições. O refino do aço é realizado em conversores a oxigênio por meio de transformações químicas endotérmicas, nas quais se utiliza como fonte de energia o próprio calor imanente do gusa líquido. Os objetivos precípuos desta etapa de refino

\footnotetext{
${ }^{14}$ No período de 1994 a 2006 os investimentos em P\&D totalizaram US\$ 66,9 milhões, dos quais US\$ 11,4 milhões (17\%) no segmento de aços planos, US $\$ 6,6$ milhões $(9,9 \%)$ no segmento de aços longos e US\$ 48,9 milhões (73,1\%) no segmento de aços especiais. Entretanto, sobre o montante total investido US\$18,9 bilhões, foram destinados ao segmento de aços planos US\$12,3 bilhões em melhoria de processo, treinamento de pessoal, meio ambiente, P\&D, automação e outros, ou seja, $(65 \%)$ do total investido, demonstrando a importância deste segmento.
} 
são os ajustes da quantidade de carbono, entre outros elementos de liga, à proporção necessária para a obtenção das propriedades desejadas e a redução para níveis aceitáveis de elementos residuais, como enxofre, nitrogênio e oxigênio. O processo mais difundido de solidificação é o lingotamento contínuo (RIZZO, 2005).

A terceira fase do processo de fabricação do aço é a laminação, no qual o aço em processo de solidificação é deformado mecanicamente e transformado em produtos siderúrgicos utilizados pela indústria de transformação, como: chapas grossas e finas; bobinas; vergalhões; arames; perfilados; barras; e etc.

Além das etapas do processo de fabricação do aço, é importante ressaltar como funciona o planejamento e a programação da produção do setor siderúrgico, que possui uma interface direta com o PDP.

Basicamente, as empresas possuem sistemas integrados de planejamento e controle da produção, buscando mais agilidade e flexibilidade para atender ao prazo de entrega, ter melhor controle da carteira de pedidos, reduzirem estoques, otimizar a utilização dos recursos e gerenciar as restrições da produção. As vendas são realizadas contra pedidos "make to order", sendo que é ofertada a capacidade dos equipamentos de produção para que a área de vendas realize suas vendas com três meses de antecedência, cada produto tem uma rota de fabricação e um tempo de processo "lead time", que são considerados para ser dado o início na sua produção feito pelo planejamento. A área de marketing organiza, na disponibilidade ofertada, os produtos vendidos e orienta a distribuição segundo as capacidades limites acertada previamente no Plano de Venda e Produção (PVP). O Plano de Vendas e Produção é elaborado anualmente e leva em consideração as metas de venda e produção, restrições operacionais, rendimentos de produtos, consumo de matériaprima e quadro de grandes paradas de equipamentos.

Conforme Oliveira (2004), com a evolução da tecnologia, as fases de redução, refino e laminação estão tendo seus tempos de processo reduzidos, assegurando maior velocidade na produção. As usinas de aço do mundo inteiro segundo o seu processo produtivo classificam-se em: integradas que operam as três fases básicas (redução, refino e laminação); e semi-integradas que operam duas fases (refino e laminação). As usinas integradas promovem a transformação do minério de ferro em produtos siderúrgicos semi-acabados ou acabados (laminados). A figura 13 ilustra as principais fases do processo produtivo integrado. 


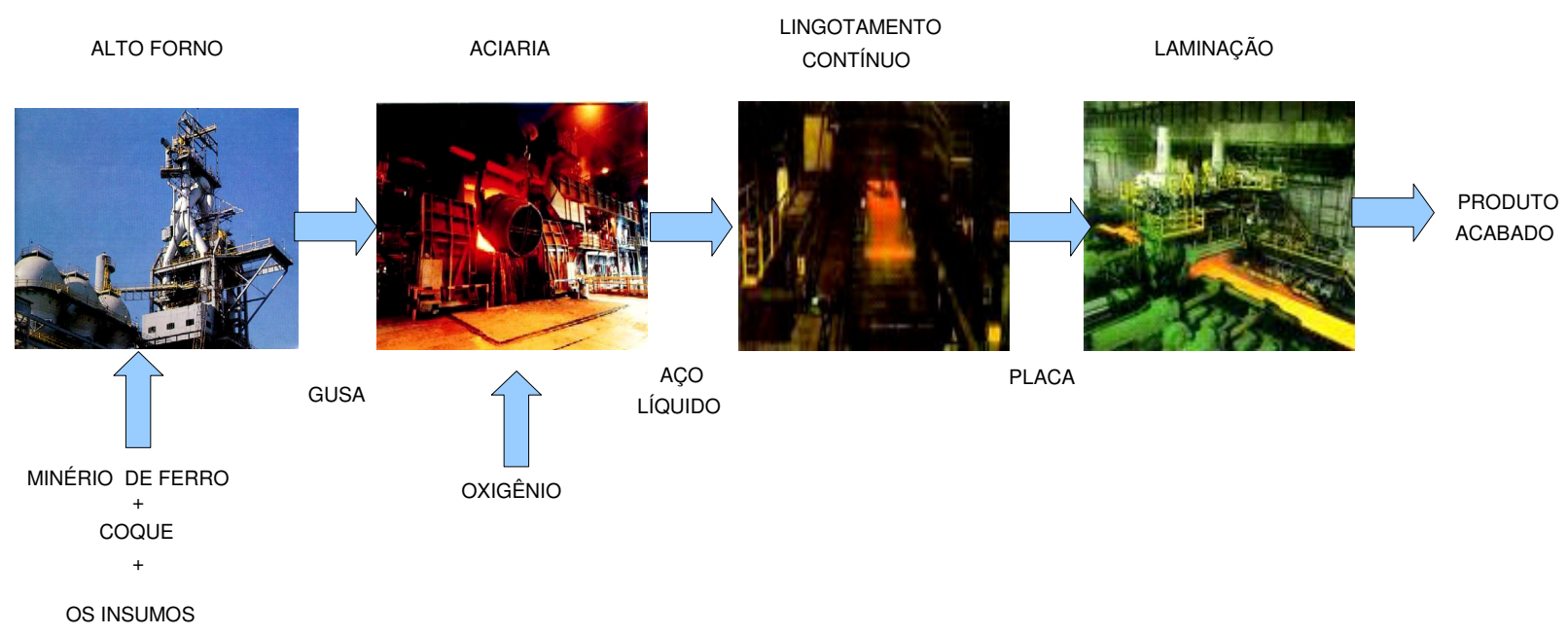

Figura 13 - Usina integrada a coque.

Fonte: Elaborado pelo autor com base em Mourão (2007).

O processo produtivo das usinas semi-integradas começa com a fusão de sucata de aço em forno elétrico a arco, e depois segue basicamente o mesmo procedimento das usinas integradas (PAULA, 2001).

Após a fabricação do aço, ele é laminado, à semelhança do que ocorre nas usinas integradas. As usinas que operam segundo este processo são também denominadas minimills, designação que ressalta o caráter mais compacto da produção semi-integrada e a escala mínima bastante inferior à das usinas integradas. A capacidade de operar eficientemente em menor escala é decorrência direta da possibilidade de se dispensar os altos-fornos, equipamentos extremamente propensos a retornos crescentes de escala. A indivisibilidade representada pela operação dos altos-fornos a coque impõe às usinas integradas um tamanho mínimo de pelo menos 3 milhões de toneladas por ano, ao passo que as minimills operam competitivamente com escalas de 250 mil toneladas por ano no segmento de aços não-planos e de 1 milhão de toneladas por ano na produção de planos. A figura 14 mostra as principais fases do processo produtivo semi-integrado. 


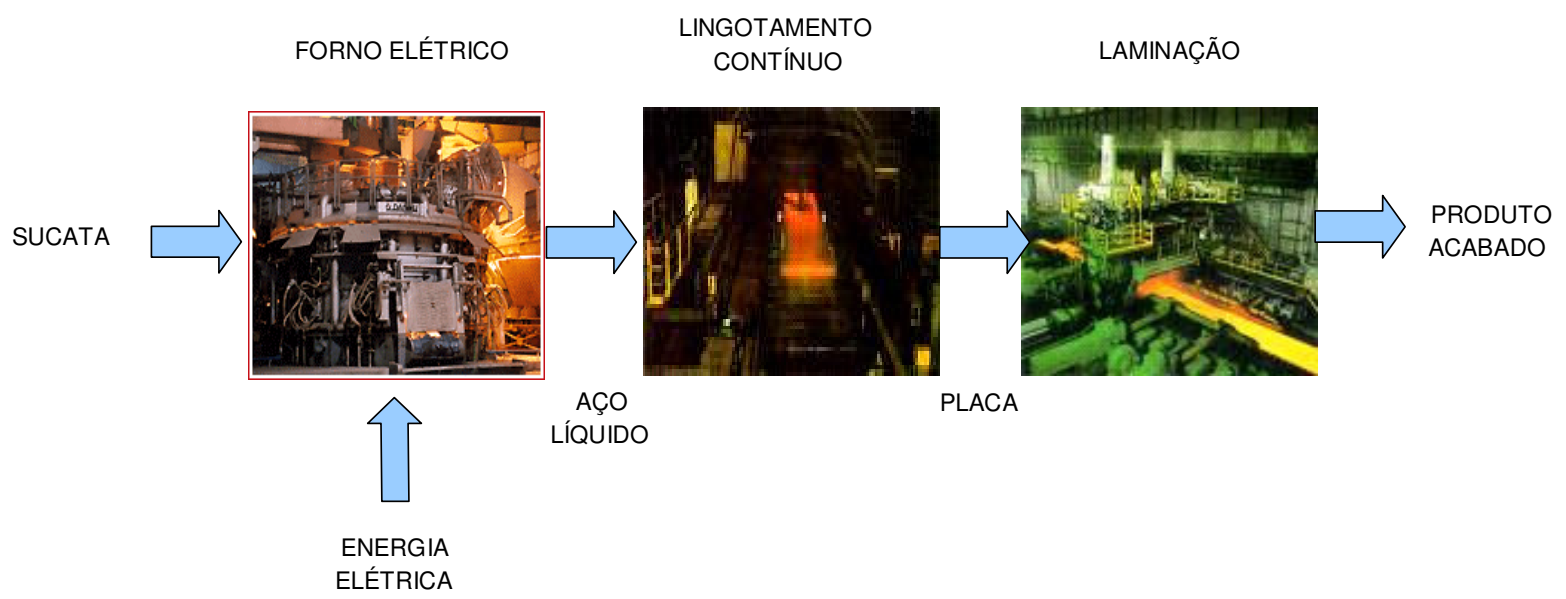

Figura 14 - Usina semi-integrada.

Fonte: Elaborado pelo autor com base em Mourão (2007).

Existem ainda unidades produtoras chamadas de não integradas, que operam apenas uma fase do processo: redução ou laminação. No primeiro caso estão os produtores de ferro gusa, que têm como característica comum o emprego de carvão vegetal em altos fornos para redução do minério. No segundo, estão os relaminadores, geralmente de placas e tarugos, adquiridos de usinas integradas ou semi-integradas e os que relaminam material sucatado. No mercado produtor, ainda operam unidades de pequeno porte que se dedicam exclusivamente a produzir aço para fundições.

Após a produção, os produtos siderúrgicos são enviados para industrialização e processamento nos principais setores consumidores de aço (PINHO, 2001): automobilístico; autopeças; construção civil; embalagens; eletro-eletrônico; utilidades domésticas; agrícola; petrolífero; naval; e bens de capital.

De acordo com Mourão (2007), os produtos siderúrgicos ${ }^{15}$ são classificados conforme o grau de acabamento, a forma geométrica, a composição química e o grau de tratamento superficial. Quanto à forma, são agrupados em três grandes classes: produtos planos, produtos longos e semi-acabados.

\footnotetext{
${ }^{15}$ A designação do grau, tipo e classe do aço utiliza uma letra, número, símbolo ou nome. Existem vários sistemas de designação para aços, como o Society of Automotive Engineers (SAE), American Iron and Steel Institute (AISI), American Society of Testing and Materials (ASTM) e Associação Brasileira de Normas Técnicas (ABNT).
} 
a) No que concerne ao grau de acabamento, os produtos podem ser classificados em semi-acabados e acabados, conforme descrito abaixo:

- Produtos semi-acabados: oriundos de processo de lingotamento contínuo ou de laminação de desbaste, destinados a posterior processamento de laminação ou forjamento a quente. A forma final de processo siderúrgico desses produtos não é definida, ou seja, eles requerem um processo de acabamento posterior, realizado através da laminação ou do forjamento, para o estabelecimento de sua espessura, largura, comprimento, diâmetro, etc.;

- Produtos acabados: cuja forma final já está concluída, ou seja, já foram submetidos a todas as etapas de produção e estão prontos para a utilização em sua aplicação final.

b) Quanto à forma geométrica, os produtos siderúrgicos são classificados em:

- Aços carbono planos revestidos e não revestidos (chapas e bobinas);

- Aços especiais ou ligados planos (chapas e bobinas);

- Aços carbono longos (barras, perfis, fio-máquina, vergalhões, arames e tubos sem costura);

- Aços especiais ou ligados longos (barras, fio-máquina, arames e tubos sem costura).

c) No que diz respeito à composição química há os aços carbono e os aços especiais:

- Aços carbono se caracterizam pela proporção reduzida de elementos de liga, de composição química definida em faixas amplas, são por isso conhecido como aços ao carbono ou de baixa liga;

- Aços especiais apresentam alto percentual de carbono e/ou adição de elementos de liga, principalmente metálicos, que Ihes fornecem propriedades específicas quanto à resiliência mecânica, à corrosão, e as características eletromagnéticas. Esses aços são utilizados no mesmo tipo de aplicação que os aços planos e longos, e são escolhidos sempre que as especificações técnicas demandem características capazes de garantir desempenho superior em relação a uma série de requisitos.

Os produtos planos, foco do presente trabalho, são resultado de processo de laminação cuja largura é extremamente superior à espessura, e são comercializados na forma de chapas e bobinas de aços carbono e especiais (MOURÃO, 2007). Os produtos planos constituem o mais importante segmento do mercado siderúrgico 
mundial, tanto em tonelagem, quanto em termos financeiros (PAULA, 1998). Os produtos siderúrgicos do segmento de aços planos podem ser subdivididos em revestidos e não revestidos, segundo a presença ou não de revestimento anticorrosivo. O revestimento pode ser feito com uma ampla variedade de materiais, destacando-se o zinco (chapas galvanizadas), o estanho (folhas-de-flandres) e 0 cromo (chapas cromadas). Estes podem ter as características ilustradas na figura 15 , bem como as empresas produtoras.

\begin{tabular}{|c|c|c|c|c|c|c|c|}
\hline \multirow{2}{*}{\multicolumn{2}{|c|}{ Produtos }} & \multicolumn{6}{|c|}{ Empresas } \\
\hline & & \multirow{2}{*}{$\begin{array}{c}\text { Acesita } \\
x\end{array}$} & \multirow{2}{*}{$\frac{\text { CSN }}{x}$} & \multirow{2}{*}{$\frac{\text { COSIPA }}{x}$} & \multirow{2}{*}{\begin{tabular}{|c|} 
CST \\
$x$
\end{tabular}} & \multirow{2}{*}{\begin{tabular}{|c|} 
Gerdau \\
$\mathrm{x}$
\end{tabular}} & \multirow{2}{*}{$\begin{array}{c}\text { USIMINAS } \\
x\end{array}$} \\
\hline & Placas & & & & & & \\
\hline 흥 응 & Chapas e Bobinas Grossas & $x$ & $x$ & $x$ & $x$ & & $x$ \\
\hline ○ \ & Chapas e Bob. a Quente & $x$ & $x$ & $x$ & $x$ & & $x$ \\
\hline$\frac{\pi}{2}, \frac{\pi}{2}$ & Chapas e Bobinas a Frio & $x$ & $x$ & $x$ & $x$ & & $x$ \\
\hline$\overline{0}$ & Folhas Não Revestidas & & $x$ & & & & $x$ \\
\hline & Folhas para Embalagens & & $x$ & & & & \\
\hline$=\frac{1}{0}$ & Chapas Zincadas a Quente & & $x$ & & $x$ & & $x$ \\
\hline 崖 & Chapas Eletro-Galvanizadas & & & & & & $x$ \\
\hline$\frac{\pi}{\pi} \underset{\pi}{\mathbb{\pi}}$ & Chapas Ligas Alumínio-zinco & & $x$ & & & & \\
\hline & Chapas Pré-Pintadas & & $x$ & & & & \\
\hline$\stackrel{\mathscr{0}}{\mathbb{0}}$ & Chapas Outros Aços ligados & $x$ & & & & & \\
\hline $\begin{array}{c}0 \\
0 \\
0 \\
0\end{array}$ & Chapas Inoxidáveis & $x$ & & & & & \\
\hline$\frac{\frac{\pi}{\pi}}{\frac{\pi}{U}}$ & Chapas Siliciosas & $x$ & & & & & \\
\hline
\end{tabular}

Figura 15 - Produtos planos distribuídos por características e as siderúrgicas brasileiras que os produzem.

Fonte: IBS (2007).

Os produtos mostrados na figura 15 são:

- Não revestidos em "aços carbono": bobinas e chapas grossas do laminador de tiras a quente (5 milímetros < espessura > 12,7 milímetros); bobinas e chapas grossas do laminador de chapas grossas (espessura $>12,7$ milímetros); bobinas e chapas finas laminadas a quente; bobinas e chapas finas laminadas a frio; 
- Revestidos em "aços carbono": folhas para embalagem (folhas de flandres recobertas com estanho - e folhas cromadas); bobinas e chapas eletrogalvanizadas; bobinas e chapas zincadas a quente; bobinas e chapas de ligas alumínio-zinco; bobinas e chapas pré-pintadas;

- "Aços especiais": bobinas e chapas em aços ao silício (chapas elétricas); bobinas e chapas em aços inoxidáveis; bobinas e chapas em aços ao alto carbono (carbono $\geq 0,50 \%$ ) e em outros aços ligados.

Os produtos longos são resultado de processo de laminação, cujas seções transversais têm formato poligonal e seu comprimento é extremamente superior à maior dimensão da seção, sendo ofertados em aços carbono e especiais (IBS, 2007). A figura 16 mostra como os produtos longos estão distribuídos e quais são as siderúrgicas produtoras.

\begin{tabular}{|c|c|c|c|c|c|c|c|}
\hline \multirow{2}{*}{\multicolumn{2}{|c|}{ Produtos }} & \multicolumn{6}{|c|}{ Empresas } \\
\hline & & \multirow{2}{*}{$\begin{array}{c}\text { Aços Vilares } \\
\mathrm{x}\end{array}$} & \multirow{2}{*}{$\frac{\text { Belgo-Mineira }}{x}$} & \multirow{2}{*}{$\frac{\text { Gerdau }}{x}$} & \multirow{2}{*}{$\begin{array}{c}\text { Siderúrgica } \\
\text { Barra Mansa } \\
x\end{array}$} & \multirow{2}{*}{$\frac{\text { V \& M do Brasil }}{x}$} & \multirow{2}{*}{$\frac{\text { Villares Metals }}{\mathrm{x}}$} \\
\hline & Lingotes, Blocos e Tarugos & & & & & & \\
\hline \multirow{4}{*}{ 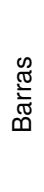 } & Aço Carbono & $x$ & $x$ & $x$ & $x$ & $x$ & $x$ \\
\hline & Aço Constr. Mecânica Ligado & $x$ & & $x$ & & $x$ & $x$ \\
\hline & Aço Inoxidável/ & & & $x$ & & & $x$ \\
\hline & Aço p/Ferram. e Matrizes & & & $x$ & & & $x$ \\
\hline \multirow{5}{*}{ 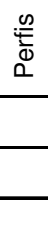 } & Leves & & $x$ & $x$ & $x$ & & $x$ \\
\hline & Médios e Pesados & & $x$ & $x$ & $x$ & & $x$ \\
\hline & Fio-Máquina & $x$ & $x$ & $x$ & $x$ & & \\
\hline & Vergalhões & & $\mathrm{x}$ & $\mathrm{x}$ & $\mathrm{x}$ & & \\
\hline & Tubos sem Costura & & & & & $\mathrm{x}$ & $\mathrm{x}$ \\
\hline
\end{tabular}

Figura 16 - Produtos longos distribuídos por características e as siderúrgicas brasileiras que os produzem.

Fonte: IBS (2007).

$\mathrm{Na}$ figura 17 estão representados os produtos trefilados. Segue as principais características desses produtos:

- Aços carbono: perfis leves (altura < 80 milímetros); perfis médios (80 milímetros < altura $\leq 150$ milímetros); perfis pesados (altura > 150 milímetros); vergalhões; fio-máquina (principalmente para arames); barras (qualidade construção civil); tubos sem costura; e trefilados; 
- Aços ligados/especiais: fio-máquina (para parafusos e outros); barras em aços construção mecânicas; barras em aços ferramenta; barras em aços inoxidáveis e para válvulas; tubos sem costura; e trefilados.

\begin{tabular}{|l|c|c|c|c|c|}
\hline \multirow{2}{*}{ Produtos } & \multicolumn{5}{|c|}{ Empresas } \\
\cline { 2 - 6 } & Aços Vilares & Belgo-Mineira & Gerdau & $\begin{array}{c}\text { Siderúrgica } \\
\text { Barra Mansa }\end{array}$ & Villares Metals \\
\hline Arames & $\mathrm{x}$ & $\mathrm{x}$ & $\mathrm{x}$ & $\mathrm{x}$ & \\
\hline Barras & $\mathrm{x}$ & $\mathrm{x}$ & $\mathrm{x}$ & & $\mathrm{x}$ \\
\hline
\end{tabular}

Figura 17 - Produtos trefilados distribuídos por características e as siderúrgicas brasileiras que os produzem.

Fonte: IBS (2007).

\subsection{A competitividade da siderurgia brasileira}

A competitividade da siderurgia brasileira está bastante associada à qualidade e preços do minério de ferro, reduzidos custos operacionais, e logística de insumos, mas ela também resulta de uma combinação de vários outros fatores como (IBS, 2007): modernidade das usinas, alta produtividade dos equipamentos, qualidade dos recursos humanos, modelos eficazes de gestão e qualidade de produtos.

Para obter estas vantagens competitivas, a siderurgia nacional empreendeu um vigoroso programa de inovação tecnológica, após a privatização, dividido em dois booms de investimentos, conforme dados do IBS (2007).

O primeiro foi nos anos 1974-1983, em face à expansão e implantação das empresas siderúrgicas estatais. Nesse período, o investimento anual médio atingiu US\$ 2 bilhões. Nos anos 1984-1993, o investimento médio anual regrediu para US\$ 476 milhões (PAULA, 2002).

O segundo boom iniciou-se em 1994, sendo que, no período 1994-2000, o investimento médio anual elevou-se para US\$ 1,45 bilhão. Tão ou mais importante do que a retomada dos investimentos foi à mudança da destinação destes, considerando o qüinqüênio 1995-1999, 31,4\% dos investimentos foram destinados à laminação, visando naturalmente ao enobrecimento do mix de produção. Um fator importante a ser destacado em relação a este boom é que ele objetivou a melhoria da qualidade dos produtos e a otimização da estrutura, aumentando a capacidade nominal da siderurgia brasileira de 28,2 para 33,0 milhões de toneladas, ocupando o 
9 lugar no ranking de produção mundial de aço em 2005 e liderando a produção na América latina, conforme mostra a tabela 12.

Tabela 12 - Produção de aço bruto da América latina.

\begin{tabular}{l|c|c|c|c|c}
\hline \multicolumn{1}{c|}{ EMPRESA } & $\mathbf{2 0 0 2}$ & $\mathbf{2 0 0 3}$ & $\mathbf{2 0 0 4}$ & $\mathbf{2 0 0 5}$ & $\mathbf{2 0 0 6}$ \\
\hline \hline Brasil & 29.604 & 31.147 & 32.909 & 31.610 & 30.901 \\
\hline México & 14.010 & 15.178 & 16.730 & 16.195 & 16.304 \\
\hline Argentina & 4.364 & 5.043 & 5.133 & 5.380 & 5.533 \\
\hline Venezuela & 4.164 & 3.930 & 4.561 & 4.907 & 4.864 \\
\hline Chile & 1.279 & 1.377 & 1.579 & 1.541 & 1.627 \\
\hline Colômbia & 664 & 668 & 806 & 1.007 & 1.211 \\
\hline Peru & 611 & 669 & 726 & 790 & 896 \\
\hline Trinidade e Tobago & 817 & 903 & 815 & 712 & 672 \\
\hline América Central & 265 & 283 & 292 & 255 & 364 \\
\hline Cuba & 269 & 210 & 193 & 245 & 257 \\
\hline Paraguai & 80 & 91 & 115 & 101 & 103 \\
\hline Equador & 69 & 80 & 72 & 83 & 86 \\
\hline Uruguai & 34 & 40 & 58 & 64 & 57 \\
\hline TOTAL & $\mathbf{5 6 . 2 3 0}$ & $\mathbf{5 9 . 6 1 9}$ & $\mathbf{6 3 . 9 8 9}$ & $\mathbf{6 2 . 8 9 0}$ & $\mathbf{6 2 . 8 7 5}$ \\
\hline
\end{tabular}

Fonte: IBS (2007).

Segundo Paula (2002), a indústria siderúrgica brasileira montou seu parque com tecnologias adquiridas externamente, embora tenha conseguido absorver a tecnologia de operação e manutenção, não conseguiu desenvolver um background técnico capaz de desenvolver tecnologias de novos processos. Logo esses investimentos além de aumentar a capacidade nominal, habilitam a produção para fabricação de novos mix de produtos.

Vale destacar que o setor siderúrgico se caracteriza por um aparato vasto e complexo, com amplo espaço para constante aprimoramento da tecnologia de processo. No sentido de ações tecnológicas, se direciona de acordo com as necessidades dos consumidores, diferentemente dos setores que se movem por rápidas e grandes inovações tecnológicas.

O setor siderúrgico é considerado maduro em termos tecnológicos, sendo que a baixa intensidade de seus gastos em P\&D constitui o indicador mais característico deste fato (PINHO, 2001). Conforme IBS (2007), no período de 1994-2006 os investimentos do setor siderúrgico foram de US\$18,9 bilhões, sendo 4,5\% destinados à modernização e automação de processos e pesquisa e desenvolvimento de novos produtos. Estes 4,5\% representam US\$ 845 milhões, dos 
quais US\$ 693 milhões são referentes a aplicação em informática e automação, US\$ 85 milhões com treinamento de pessoas e US\$ 67 milhões com pesquisa \& desenvolvimento, que significa apenas $0,35 \%$ do total investido no setor siderúrgico no período. Os programas de investimentos definidos pelas empresas do parque siderúrgico brasileiro, no período de 2007 a 2012, compreendem investimentos de US $\$ 17,2$ bilhões que elevarão a capacidade instalada dos atuais 37,1 milhões de t/ano para 52,2 milhões de t/ano. Estes investimentos estão distribuídos da seguinte forma: $(50,4 \%)$ no segmento de aços planos, $(40,2 \%)$ no segmento de aços longos, e $(9,4 \%)$ no segmento de aços especiais. A tabela 13 ilustra como foram aplicados os investimentos por áreas e as perspectivas de investimentos futuros.

Tabela 13 - Investimentos do setor siderúrgico por área de aplicação.

\begin{tabular}{l|l|l|l|l}
\hline \multirow{2}{*}{ ÁREAS } & \multicolumn{2}{l|}{$\begin{array}{l}\text { REALIZADOS } \\
\mathbf{1 9 9 4 / 2 0 0 6}\end{array}$} & \multicolumn{2}{l}{$\begin{array}{l}\text { PREVISTOS } \\
\mathbf{2 0 0 7 / 2 0 1 2}\end{array}$} \\
\cline { 2 - 5 } & US\$ Mil & $\%$ & US\$ Mil & $\%$ \\
\hline \hline Matérias-Primas & 320.344 & 1,69 & 466.943 & 2,72 \\
\hline Energia & 753.789 & 3,98 & 294.807 & 1,72 \\
\hline Redução & 3.684 .736 & 19,48 & 3.575 .648 & 20,85 \\
\hline Aciaria & 1.641 .167 & 8,67 & 2.205 .642 & 12,86 \\
\hline Lingotamento & 1.617 .916 & 8,55 & 1.907 .017 & 11,12 \\
\hline Laminação & 5.076 .651 & 26,83 & 4.568 .586 & 26,64 \\
\hline Meio ambiente & 1.523 .410 & 8,05 & 683.694 & 3,99 \\
\hline Informática/Automação & 692.720 & 3,66 & 355.111 & 2,07 \\
\hline P\&D & 66.891 & 0,35 & 68.195 & 0,40 \\
\hline Treinamento de pessoal & 85.506 & 0,45 & 127.456 & 0,74 \\
\hline Outros & 3.456 .211 & 18,27 & 2.899 .025 & 16,90 \\
\hline TOTAL & $\mathbf{1 8 . 9 1 9 . 3 4 1}$ & $\mathbf{1 0 0 , 0}$ & $\mathbf{1 7 . 1 5 2 . 1 2 4}$ & $\mathbf{1 0 0 , 0}$ \\
\hline Fonte: IBS (2007) & & & & \\
\hline
\end{tabular}

Fonte: IBS (2007).

Visto que, o amadurecimento do setor siderúrgico se deve também pelo acúmulo de competência tecnológica, que está associada a determinados pontos (OLIVEIRA, 2004): investimentos; processos e organização da produção; produtos; e equipamentos. Segue detalhamento dos quatro tipos de competências tecnológicas, cujo desenvolvimento é vital para uma empresa siderúrgica:

- Investimentos: uma usina siderúrgica demanda grandes investimentos; portanto é fundamental desenvolver competência para tomada de decisões e controle no que refere à expansão da planta e engenharia de projetos, estas atividades podem ser confiadas aos fornecedores de equipamentos e processos, a outras companhias siderúrgicas, e a firmas especializadas em 
engenharia de projetos. Entretanto, quanto mais se delega essas atividades a terceiros, menor o seu controle sobre os custos, os riscos e a administração geral do projeto;

- Processos e organização da produção: a competência das siderúrgicas em adaptar a tecnologia dos processos às condições locais e para aprimorar os parâmetros dos processos e os métodos de organização da produção é fundamental não só para melhorar o desempenho, mas também para ganhar e manter a competitividade. Além disso, as siderúrgicas utilizam de sistemas automatizados de controle de processos, desenvolve modelos matemáticos, métodos e sistemas de organização da produção, visando melhorar o rendimento de fabricação do aço;

- Produtos: os produtos da indústria do aço são utilizados em diferentes setores e a demanda de produtos mais nobres para fins específicos, como aço galvanizado para o setor automotivo, tornaram-se vitais para competir no mercado, tornando ainda mais premente o desenvolvimento da competência de melhoramento contínuo dos produtos existentes e/ou o desenvolvimento de novos produtos;

- Equipamentos: as siderúrgicas operam equipamentos pesados e complexos, cujo desempenho está associado a serviços efetivos de manutenção e reforma planejada. Estes serviços podem ser terceirizados, mas assim as siderúrgicas ficarão com um conhecimento limitado a respeito do funcionamento do equipamento e sua complexidade, o que em longo prazo pode prejudicar o desempenho em geral.

As vantagens competitivas da siderurgia brasileira, em particular, das usinas integradas a coque produtoras de aços planos, no que se relaciona aos custos de produção, encontram-se baseadas nos menores custos salariais e de minério de ferro. Por outro lado, as maiores desvantagens competitivas são as despesas financeiras e, em menor escala, os custos do carvão mineral (PAULA, 2002).

A pesar de, o setor siderúrgico possuir certa maturidade tecnológica e, conseqüentemente, relativo baixo investimento em pesquisa e desenvolvimento, se qualifica para ser analisado neste trabalho devido à dependência do negócio estar no sucesso de fabricação do aço, o que ocasiona maior complexidade e necessidade de integração na fase de projeto do processo no PDP. A seguir na 
próxima seção é mostrada a situação em termos de inovação tecnológica, como se encontra o setor siderúrgico brasileiro.

\subsection{Inovação tecnológica da siderurgia brasileira}

Segundo Oliveira (2004), a inovação tecnológica do setor siderúrgico destaca como aspectos principais: a maturidade tecnológica do setor; as estratégias tecnológicas mais conservadoras; a baixa apropriabilidade dos resultados de inovações, especialmente em tecnologia de processo; a importância crescente dos fornecedores de equipamentos e dos clientes no desenvolvimento tecnológico do setor; e as iniciativas de cooperação em P\&D.

A Associação Nacional de Pesquisa, Desenvolvimento e Engenharia das Empresas Inovadoras (ANPEI) realiza uma pesquisa, de periodicidade trienal, que faz um levantamento sobre as atividades inovativas das empresas, que tendem a ter pequena variação no curto prazo, o que não justificaria uma coleta anual. Porém, as atividades de P\&D podem sofrer fortes impactos das condições conjunturais da economia, em especial no que diz respeito aos recursos alocados para sua condução. Por esta razão, nos anos em que não se realizam pesquisas de inovação, são feitas as de $P \& D$, mais restritas do que as anteriores, de modo a se dispor de informações anuais sobre o tema.

Os resultados da base de dados da ANPEI, ano base 2004, no qual participaram 31 empresas do setor siderúrgico, confirmam alguns dos aspectos principais de inovação tecnológica deste setor, citados no parágrafo anterior. Nesta pesquisa da ANPEI, a siderurgia foi classificada como tendo médio-baixa intensidade tecnológica $(33,4 \%)^{16}$, porém acima da média da indústria nacional (33,3\%). Das empresas que participaram da pesquisa, 17 empresas $(54,8 \%)$ realizaram contratação de atividades de $\mathrm{P} \& \mathrm{D}$, tendo como principais motivos desta contratação 0 aprimoramento de produtos e a necessidade de conquistar novos mercados.

\footnotetext{
${ }^{16}$ Os dados da ANPEI demonstram respectivamente os baixos valores de taxa de inovação e de intensidade tecnológica do setor siderúrgico no período de $1998-2000(22,3 \%$ e $0,48 \%)$ e no período de 2001-2003 (22,6\% e 0,29\%). Vale a pena destacar, que o conceito de taxa de inovação corresponde à relação entre o número de empresas que realizaram alguma inovação (de produto ou de processo) em determinado período sobre o número total de empresas industriais, e a intensidade tecnológica, mede a relação entre os seus investimentos em P\&D e o seu faturamento.
} 
Referente ao montante despendido em P\&D, o segmento siderúrgico foi um dos mais baixos, com $(0,16 \%)$ de gastos em P\&D por receita bruta, ficando na frente apenas do setor de alimentos e bebidas $(0,12 \%)$. O número de pessoas em dedicação exclusiva às atividades de P\&D apresentou em média um total de 20 pessoas por empresa, sendo distribuídos nos seguintes níveis de qualificação: doutor (1); mestres (4); graduados (3); técnicos de nível médio (7); e outros de suporte (5).

Um dos indicadores mais utilizados para se mensurar o esforço de inovação tecnológica é o número de patentes, e o setor siderúrgico se destacou no depósito de patentes no Brasil, com 15 patentes por empresa concedida em média nos últimos 10 anos e apenas uma patente no exterior. A média do faturamento anual gerado por produtos tecnologicamente novos ou aperfeiçoados, lançados há menos de 5 anos nas empresas siderúrgicas ficou em torno de 17,3\%. Destacando que este indicador apresenta bastante variação de acordo com o segmento industrial.

Finalizando a descrição da pesquisa ANPEI, os resultados demonstram também uma preocupação do setor siderúrgico com o processo de melhorias contínuas, prova disso é o indicador de redução dos custos, decorrentes de melhorias de processo, no qual a maior redução foi na siderurgia com um valor de $R \$ 6,3$ milhões por empresa.

É interessante acrescentar que as siderúrgicas brasileiras passaram por programas de capacitação tecnológica importante tanto na sua capacidade produtiva como na ação de esforços para a consolidação de estruturas formais de Pesquisa e Desenvolvimento, destacando que a inovação tecnológica do setor siderúrgico se caracteriza pela (OLIVEIRA, 2004): baixa intensidade dos esforços tecnológicos; redução das estruturas próprias de P\&D; redução dos dispêndios para a aquisição de equipamentos e materiais; melhoria da qualificação dos recursos humanos; e a manutenção do escopo das atividades tecnológicas internas da empresa.

Conforme Pinho (2001), a intensidade dos esforços em P\&D na indústria siderúrgica varia significativamente entre os segmentos produtores, em resposta aos diferentes níveis de exigência dos consumidores. É maior no segmento de aços especiais e menores na maior parte dos laminados longos comuns. Mesmo nesse último segmento há, porém, importante diversidade quanto ao espaço para o desenvolvimento de tecnologia de produto. Entre os itens menos elaborados 
prevalece a característica da maturidade do produto e as trajetórias tecnológicas definem no presente escassas oportunidades de inovação.

Entretanto, entre os produtos sujeitos a maior elaboração, como por exemplo, laminados planos revestidos e aços especiais, os esforços de geração de variedades com especificações superiores são bastante importantes para a indústria siderúrgica manter a sua participação no mercado. Percebe-se que cabe aos consumidores mais sofisticados desta indústria, notadamente o complexo automotivo, a tarefa de requisitar inovações, cada vez mais desenvolvidas através de mecanismos de parceria entre as siderúrgicas e seus clientes (OLIVEIRA, 2003). Configura-se assim, uma situação em que o desenvolvimento da tecnologia do produto é usualmente "puxado pela demanda" (PAULA, 2002).

A siderurgia brasileira encontra-se atualizada tecnologicamente, em consonância com as tendências da siderurgia mundial (IBS, 2007). As principais mudanças tecnológicas das siderúrgicas brasileiras baseiam-se em mudanças técnicas incrementais de processos desenvolvidas no exterior e, atualmente, a estratégia de crescimento deste setor contempla o enobrecimento de produtos para o mercado interno e exportação crescente de semi-acabados. O setor siderúrgico também tem concentrado esforços de inovação tecnológica em desenvolvimento de novos produtos e aplicações, deixando o desenvolvimento de processos para os fabricantes dos equipamentos (PINHO; LOPES, 2003). Acrescentando-se a isso, inúmeras inovações de menor porte têm contribuído para a melhoria dos indicadores de qualidade e rendimento de equipamentos e da mão-de-obra (PINHO, 2001).

Esta seção identificou, por meio de dados secundários coletados de diversas fontes, os principais indicadores de inovação em P\&D, os programas de capacitação tecnológica, as características de inovação de cada segmento do setor siderúrgico, e a constante necessidade de adequação as tendências tecnológicas do mercado.

Concluindo este capítulo, buscou-se caracterizar a manufatura do setor siderúrgico, que é importante para este trabalho de análise do projeto de processo no PDP, destacando os tipos de produtos comercializados e a tecnologia envolvida em seus processos, bem como, a importância da gestão das interfaces organizacionais. Da mesma forma, foram descritos como acontece a concorrência neste setor e como as siderúrgicas brasileiras, apesar do relativo baixo investimento em P\&D, estão inovando em processo e produtos, para não ficarem defasadas em relação ao mercado mundial de aço e de produtos sucedâneos. A seguir são 
extraídos alguns tópicos, deste capítulo, que vinculam o setor siderúrgico ao tema deste trabalho:

- O setor siderúrgico se caracteriza por um aparato vasto e complexo, com amplo espaço para constante aprimoramento da tecnologia e tem concentrado esforços de inovação em desenvolvimento de novos produtos;

- Este setor é considerado maduro em termos tecnológicos, sendo que os baixos gastos em P\&D representam o indicador mais característico deste fato;

- A siderurgia depende do sucesso de fabricação do aço, o que ocasiona maior complexidade e necessidade de integração entre as áreas;

- O segmento de aços planos constitui o mais importante segmento do mercado siderúrgico mundial, tanto em tonelagem, quanto em termos financeiros.

Encerrada a etapa de caracterização do setor siderúrgico brasileiro, busca-se no próximo capítulo delinear as questões metodológicas que norteiam a proposta de pesquisa. 


\section{MÉTODOS E TÉCNICAS DE PESQUISA}

A abordagem metodológica de um trabalho de pesquisa é necessária para que as etapas de realização do trabalho sejam conduzidas com maior rigor e objetividade, com foco e limitações bem definidos, chegando-se a resultados finais confiáveis e válidos, e permitindo que a pesquisa realizada tenha repetibilidade em outro ambiente ou condição (GIL, 1999). Nesse sentido, este capítulo descreve as etapas utilizadas para construção e validação do presente trabalho. Além disso, trata da sustentação metodológica do trabalho de pesquisa, bem como as justificativas das escolhas dos métodos e técnicas adotados neste trabalho.

Os objetivos de uma pesquisa podem ser (SELLTZ et al., 1975): familiarizar com um fenômeno ou conseguir um novo entendimento sobre ele; apresentar informações sobre uma situação; verificar a freqüência com que algo acontece ou como se liga a outros fenômenos; e analisar uma hipótese de relação causal entre variáveis. Miguel (2007) destaca em seu estudo que, para atender um ou mais desses objetivos, a pesquisa desenvolve-se desde a formulação do problema até a finalização dos resultados, análise crítica e suas conclusões. O processo de pesquisa é elaborado por meio do concurso do conhecimento disponível e pela utilização correta de métodos, técnicas e procedimentos científicos. Merece ser destacado o comportamento do observador, que precisa estar guiado por métodos e técnicas específicos ajustados à natureza da pesquisa e à realidade investigada.

Por meio da revisão da literatura sobre metodologia de pesquisa, pode-se confirmar que não existe concordância sobre a tipologia de pesquisa, que podem ser classificadas segundo maneiras que diferem quanto (GODOY, 1995; MAYS; POPE, 1996; MATTAR, 1996): ao método que é condicionado aos problemas iniciais da pesquisa (método indutivo; método dedutivo; método hipotético-dedutivo; e método dialético); a natureza das variáveis pesquisadas (abordagem qualitativa e abordagem quantitativa); a natureza do relacionamento entre variáveis (descritivo ou causal); ao objetivo e grau de cristalização do problema (exploratória ou conclusiva); ao escopo da pesquisa, em termos de profundidade e amplitude (desenvolvimento teórico-conceitual; estudo de caso; levantamento tipo survey; modelamento e simulação; e pesquisa-ação). 
Constata-se na literatura, que cada abordagem metodológica possui sua particularidade e o pesquisador deve estar atento ao alinhamento entre os objetivos propostos no seu trabalho com a escolha dos métodos e técnicas de pesquisa. Portanto, na próxima seção são apresentadas as macro fases para condução do trabalho de pesquisa e as escolhas dos métodos e técnicas de pesquisa utilizadas neste trabalho.

\subsection{Fases para realização do trabalho de pesquisa}

A partir do delineamento da pesquisa sobre a fase de projeto do processo dentro do PDP, após revisão bibliográfica, conseguiu-se delimitar o problema de pesquisa, por meio das questões, objetivos e justificativas apresentados na introdução deste trabalho. O presente trabalho é dividido em três macros fases: referencial teórico; investigação empírica; e comparação das unidades de análise. A figura 18 mostra como cada macro fase é conduzida para realização do trabalho de pesquisa e os instrumentos de coleta e análise de dados; em seguida, é realizada uma descrição de cada uma das fases da pesquisa.

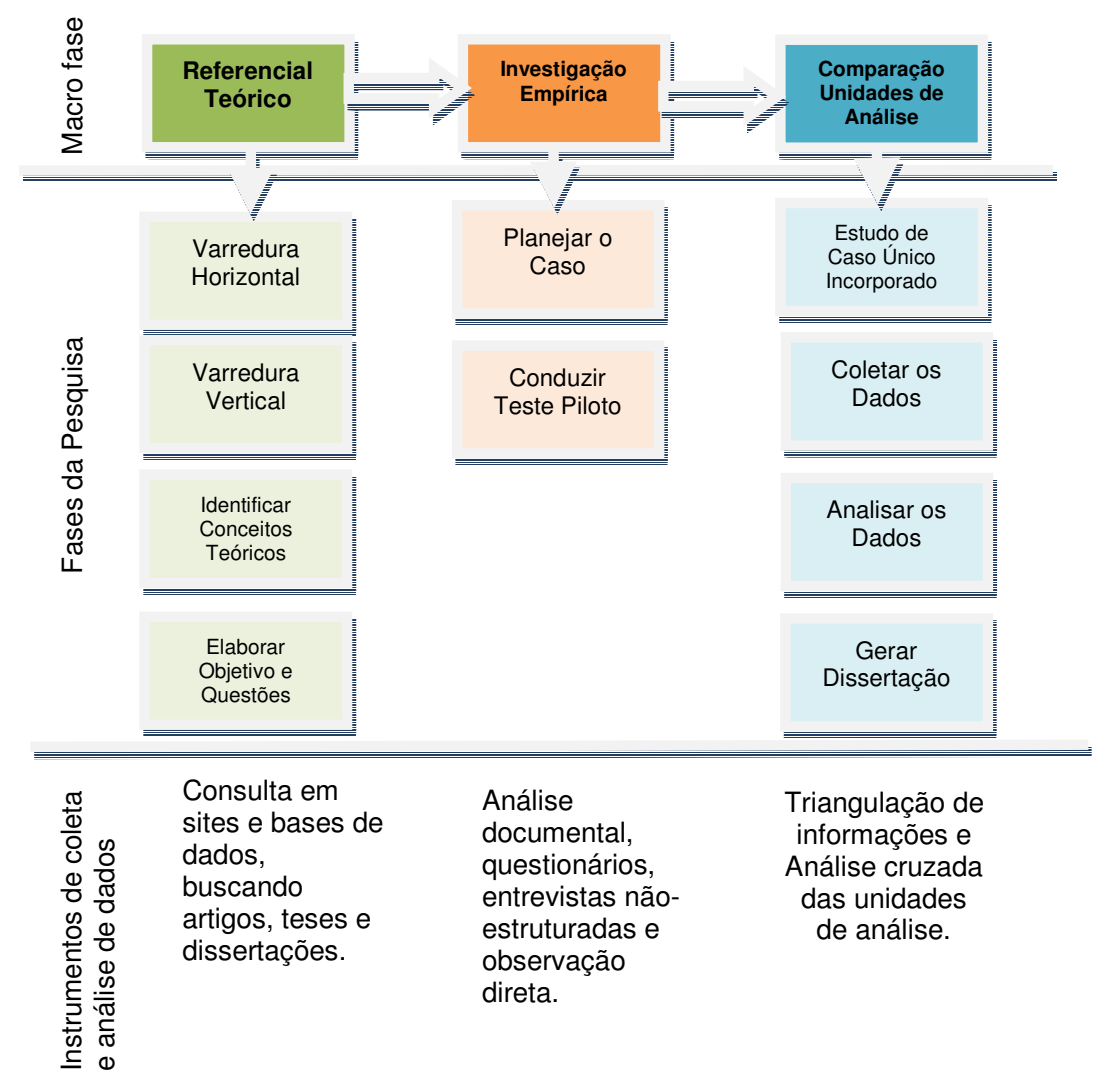

Figura 18 - Estrutura metodológica do trabalho.

Fonte: Elaborado pelo autor. 


\subsubsection{Referencial teórico}

É de suma importância a elaboração inicial de um referencial teórico para o trabalho, de forma a resultar em um mapeamento da literatura sobre o assunto. Esse mapeamento localiza o tópico de pesquisa no contexto da literatura disponível sobre o tema; além disso, a partir da revisão bibliográfica é possível identificar as lacunas onde a pesquisa pode ser justificada, bem como possibilita extrair os constructos, que são a base para a elaboração das proposições (YIN, 2001; VOSS et al., 2002).

O referencial teórico do presente trabalho, conforme apresentado no capítulo anterior, foi elaborado através de uma varredura horizontal ${ }^{17}$ sobre o processo de desenvolvimento de produtos em diferentes fontes (artigos, sites e teses). Após essa varredura, foi possível identificar três tópicos importantes relacionados ao assunto:

- A visão do PDP como um processo do negócio;

- A influência da complexidade do produto e do processo;

- A fase de projeto do processo.

Partiu-se então para uma varredura vertical ${ }^{18}$ afunilando a pesquisa na fase de projeto do processo, no qual se encontrou as principais variáveis relacionadas ao tema citada por diversos autores, e com essas informações extraíram-se o objetivo e as questões da presente pesquisa.

Concluída a macro fase de referencial teórico, o próximo passo é a escolha do caso, que é abordado na próxima seção.

\subsubsection{Investigação empírica: planejar o caso}

Após a elaboração do referencial teórico, a próxima etapa no planejamento deste trabalho corresponde à escolha do caso. No entanto, para o presente trabalho optou-se pelo estudo de caso único "incorporado" em uma organização do segmento de aços planos do setor siderúrgico brasileiro, denominada Sistema Usiminas. Segundo Yin (2001), esse tipo de estudo de caso ocorre quando, dentro de um único

\footnotetext{
${ }^{17}$ Este conceito de procurar na literatura com o objetivo de encontrar itens relevantes, vem da interpretação da figura 2.2 "Trawling and Mining for Information", citado por Hart (2001) como estratégia para planejamento e preparação de pesquisa. Neste caso, a partir de uma busca bibliográfica ampla sobre determinado tema de pesquisa.

${ }^{18}$ Segundo Hart (2001) uma varredura vertical se caracteriza por uma busca bibliográfica mais focada sobre determinado tema, selecionando itens relevantes e realizando uma análise crítica entre os itens encontrados.
} 
assunto, existem duas ou mais unidades de análise independentes entre si, mas incorporadas ao mesmo contexto.

Assim sendo, para se dar mais subsídios na análise deste trabalho de pesquisa são utilizadas duas unidades de análise desta mesma organização, ou seja, são analisadas duas plantas ${ }^{19}$ distintamente caracterizadas no mercado. Estas unidades de análise possuem partes comuns na estrutura do Processo de Desenvolvimento de Produtos, como a área de marketing que é corporativa, e outras partes específicas, como as áreas de engenharia do produto e manufatura, de acordo com as características próprias de cada unidade de análise. Apesar das unidades de análise estarem em processo de integração e terem a estrutura do PDP de forma padronizada existem diferenças que justificam a separação da análise, tais como: a quantidade e tipo de projetos desenvolvidos, características da estrutura funcional, percepção diferenciada quanto à importância das variáveis relacionadas ao PDP (identificadas no Capítulo 2 de referencial teórico), e diferença cultural das unidades de análise, em termos de referências e prioridades relacionadas à comunicação, liderança, gerenciamento e tomada de decisão.

O setor siderúrgico brasileiro foi escolhido como contexto para o estudo de caso e se justifica devido a sua complexidade organizacional, que se caracteriza pela utilização de vários equipamentos de grande porte em um processo contínuo (Alto Forno, Aciaria, Laminador, etc.) e também pela dificuldade de integração entre as áreas envolvidas no PDP (marketing, engenharia do produto e manufatura), devido principalmente a diferentes prioridades e a distância física das áreas envolvidas no desenvolvimento de novos produtos. Além disso, cada vez mais o desenvolvimento de novos produtos é importante para estas empresas, devido ao aumento constante de concorrência de materiais substitutos e exigências por qualidade e variedade de produtos pelas indústrias de base. As siderúrgicas brasileiras possuem o PDP estruturado e, deste modo, desenvolvem produtos dentro de um sistema de gestão controlado, que propicia mais subsídios à análise proposta neste trabalho, de investigar a fase de projeto do processo no PDP.

Associado a isso, vale ressaltar a importância do setor siderúrgico devido a grande geração de empregos; os altos impostos pagos; os constantes investimentos

\footnotetext{
${ }^{19}$ Para facilitar o entendimento das nomenclaturas utilizadas neste trabalho, quando se citar a Planta1 está se referindo a unidade de análise Companhia Siderúrgica Paulista que é controlada pela unidade de análise Usinas Siderúrgicas de Minas Gerais S/A (Planta-2), lembrando que as unidades de análise têm CNPJ distintos e fazem parte da mesma corporação (Sistema Usiminas).
} 
em desenvolvimento e pesquisa de novos produtos; a contribuição positiva na balança comercial; e por fomentar diversos setores da indústria de base, que são importantes para o desenvolvimento do país. No ano de 2006, os principais indicadores econômico-sociais do setor siderúrgico brasileiro demonstram a sua importância (IBS, 2007): a capacidade instalada de 37 milhões de toneladas de aço bruto/ano, ocupando o 10 lugar no ranking da produção mundial de aço; o efetivo em atividade de 107.925 empregados, sendo 57.971 de efetivo próprio e 49.954 de efetivo de terceiros; o faturamento de US\$24,9 bilhões, sendo $72,7 \%$ no mercado interno e 27,3\% no mercado externo; os impostos pagos de US $\$ 4,8$ bilhões; sendo 12,7\% direcionados à Imposto sobre Produtos Industrializados; os investimentos de US\$ 3,1 bilhões, sendo 4,1\% destinados à modernização e automação de processos, e 0,4\% à pesquisa e desenvolvimento de novos produtos; e uma participação de 1,4\% no Produto Interno Bruto nacional.

Este setor possui três segmentos significativamente distintos, com características específicas e dinâmicas próprias (IBS, 2007): aços planos comuns, aços longos comuns e o de aços especiais. Em termos de produto é significativa a diferenciação entre os tipos de aço fabricados que é muito difícil fazer qualquer generalização. Estes segmentos produtores são diferenciados quanto (PINHO, 2001): ao porte das empresas; a competitividade de mercado; a intensidade dos esforços em P\&D; e ao ritmo de inovação tecnológica. Portanto, para este trabalho foi escolhido o segmento de aços planos, que se destaca pela elevada dimensão das usinas integradas a coque, com uma capacidade mínima de pelo menos 3 milhões de toneladas/ano, e aos investimentos em inovação de processo e produtos. Além disto, dentro deste segmento, foi selecionada uma organização como caso único com duas unidades de análise desta organização, sendo um teste piloto na Planta-1 no Estado de São Paulo e mais uma unidade de análise Planta-2, em Minas Gerais, buscando assim mais elementos para análise dos dados sobre o PDP. Estas unidades de análise foram escolhidas devido a representatividade em termos de produção e as certificações de qualidade que estruturam o PDP. Relacionado a isso, a organização possui um Centro de P\&D que dá suporte as duas unidades no desenvolvimento de novos produtos.

A partir da seleção do caso e das duas unidades de análise, determinaram-se os métodos e técnicas tanto para a coleta quanto para análise dos dados. Neste 
sentido, foram empregadas múltiplas fontes de evidência: entrevistas nãoestruturadas, questionários, análise documental e observação direta.

Após definida as técnicas para a coleta de dados, um protocolo (Apêndice A) foi desenvolvido, contendo os procedimentos e regras gerais de pesquisa para sua condução e indicação da origem das fontes de informação. Dessa forma, este protocolo visa esclarecer os procedimentos utilizados no trabalho, garantir a padronização de sua aplicação em cada unidade de análise, e assim melhorar a confiabilidade na reprodução do estudo de caso (YIN, 2001; VOSS et al., 2002).

Definido o protocolo, a próxima seção visa definir os métodos e técnicas de pesquisa, e justificar suas escolhas para o presente trabalho.

\subsubsection{Investigação empírica: métodos e técnicas de pesquisa utilizados neste trabalho}

Este trabalho tem alguns objetivos, sendo que o primeiro busca uma visualização geral do PDP e os outros dois de constatar, com base na literatura, como a fase de projeto do processo no PDP está estruturada, e qual a relação de algumas variáveis (identificadas no Capítulo 2 de referencial teórico) nesta fase.

Baseado nos principais métodos e técnicas de pesquisa da literatura, citados no início deste capítulo, justifica-se a seguir as seguintes escolhas para realização deste trabalho.

A análise é indutiva, pois a linha de raciocínio é do específico para o geral. É de caráter qualitativo, devido a natureza das variáveis e métodos, cujos resultados são representados na forma descritiva, com algumas relações de causalidade muito restritas. O trabalho é de natureza exploratória, pois a literatura é relativamente limitada no foco escolhido, seja pelo tema (projeto do processo) em nível teórico, seja pela investigação empírica no setor siderúrgico nesse tema. Tanto o contexto quanto o fenômeno são importantes no presente estudo, explicando então a adoção da abordagem de estudo de caso.

As escolhas metodológicas para execução deste trabalho estão sintetizadas e destacadas em negrito na tabela 14. 
Tabela 14 - Síntese das principais características metodológicas do trabalho.

\begin{tabular}{l|l}
\hline CARACTERISTICAS METODOLÓGICAS & \multicolumn{1}{c}{ TIPOS UTILIZADOS } \\
\hline \hline Método de pesquisa & $\begin{array}{l}\text { indutivo } \\
\text { dedutivo } \\
\text { hipotético-dedutivo } \\
\text { dialético }\end{array}$ \\
\hline Abordagem do problema & $\begin{array}{l}\text { qualitativa } \\
\text { quantitativa }\end{array}$ \\
\hline Natureza das variáveis & $\begin{array}{l}\text { caráter descritivo } \\
\text { caráter causal }\end{array}$ \\
\hline Objetivos gerais da pesquisa & $\begin{array}{l}\text { exploratória } \\
\text { conclusiva }\end{array}$ \\
\hline Métodos de procedimento de pesquisa & $\begin{array}{l}\text { desenvolvimento teórico-conceitual } \\
\text { estudo de caso } \\
\text { levantamento tipo survey } \\
\text { modelamento e simulação } \\
\text { pesquisa-ação }\end{array}$ \\
\hline
\end{tabular}

Fonte: Elaborado pelo autor com base em Godoy (1995), Mays e Pope (1996), Mattar (1996).

Segundo Eisenhardt (1989), é importante utilizar múltiplas técnicas de coleta de dados para obtenção de resultados mais robustos. Portanto, para operacionalizar as escolhas metodológicas feitas neste trabalho, são empregados os instrumentos de coleta e análise de dados, definidos e destacados em negrito na tabela 15.

Tabela 15 - Síntese dos principais tipos de instrumentos de coleta e análise de dados utilizados no trabalho.

\begin{tabular}{|c|c|c|}
\hline INSTRUMENTOS & DEFINIÇÃO & $\begin{array}{c}\text { TIPOS } \\
\text { UTILIZADOS }\end{array}$ \\
\hline $\begin{array}{l}\text { Análise } \\
\text { documental }\end{array}$ & $\begin{array}{l}\text { É uma importante fonte de dados que serve para } \\
\text { complementar informação obtida por outros } \\
\text { instrumentos de coleta de dados. É dividida em duas } \\
\text { etapas: a primeira a escolha dos documentos e a } \\
\text { segunda a análise dos mesmos. }\end{array}$ & $\begin{array}{l}\text { atas de reuniões } \\
\text { documentos } \\
\text { administrativos } \\
\text { estudos formais } \\
\text { relatórios } \\
\text { arquivos } \\
\text { pareceres }\end{array}$ \\
\hline Questionário & $\begin{array}{l}\text { Obtenção das informações por meio de uma série de } \\
\text { perguntas de auto-preenchimento, que podem ser } \\
\text { abertas, fechadas ou de múltipla escolha, e que devem } \\
\text { ser respondidas por escrito, sem a presença do } \\
\text { pesquisador. }\end{array}$ & $\begin{array}{l}\text { aberto } \\
\text { fechado } \\
\text { múltipla escolha }\end{array}$ \\
\hline Entrevista & $\begin{array}{l}\text { São conversas efetuadas de maneira metódica, que } \\
\text { objetivam fornecer ao pesquisador as informações } \\
\text { necessárias. O caráter interativo desta técnica permite } \\
\text { ao pesquisador tratar de temas complexos que } \\
\text { dificilmente poderiam ser investigados de forma } \\
\text { profunda por meio de questionários. }\end{array}$ & $\begin{array}{l}\text { não-estruturada } \\
\text { semi-estruturada } \\
\text { estruturada }\end{array}$ \\
\hline
\end{tabular}

Fonte: Elaborado pelo autor com base em Lakatos e Marconi (1995), Gil (1999), Yin (2001). 
Tabela 15 - Síntese dos principais tipos de instrumentos de coleta e análise de dados utilizados no trabalho - Continuação.

\begin{tabular}{|c|c|c|}
\hline INSTRUMENTOS & DEFINIÇÃO & $\begin{array}{c}\text { TIPOS } \\
\text { UTILIZADOS }\end{array}$ \\
\hline Observação & $\begin{array}{l}\text { A interação direta entre o pesquisador e o objeto de } \\
\text { estudo e reforça a competência na extração e } \\
\text { interpretação de dados do fenômeno estudado. Estas } \\
\text { evidências geralmente são úteis para prover } \\
\text { informações adicionais sobre o tópico em estudo e para } \\
\text { se aumentar a fidedignidade das observações. Na } \\
\text { observação participante, o observador deixa de ser um } \\
\text { membro passivo e pode assumir vários papéis na } \\
\text { situação do caso em estudo e pode participar e } \\
\text { influenciar nos eventos em estudo. }\end{array}$ & $\begin{array}{l}\text { direta } \\
\text { participante }\end{array}$ \\
\hline
\end{tabular}

Fonte: Elaborado pelo autor com base em Lakatos e Marconi (1995), Gil (1999), Yin (2001).

A seguir, são descritos com mais detalhes como utilizar cada instrumento de coleta e análise de dados, adotados no presente trabalho:

- Análise documental: levantar todos os documentos envolvidos com o PDP, incluindo atas de reuniões, documentos administrativos, normas de qualidade, procedimentos, relatórios gerenciais e arquivos relacionados ao PDP. É importante considerar estes documentos para constatar se há clareza e convergência nas informações transmitidas pelos integrantes do desenvolvimento de novos produtos e as informações documentadas no PDP;

- Questionários: obter informações sobre o PDP por meio de questões abertas, que devem ser respondidas por escrito pelas áreas de marketing, engenharia do produto e manufatura, sem a presença do pesquisador. As questões abertas permitem maior grau de elaboração pelos respondentes, e o questionário como instrumento de coleta de dados se justifica devido ao respondente ter mais tempo para pensar, e em caso de dúvida ele pode pesquisar as informações corretas para responder com clareza as perguntas, isto dá maior confiabilidade nas informações;

- Entrevistas: efetuar entrevista de forma não-estruturada com a alta gerência responsável pelo PDP, com a intenção de ter uma visão geral do PDP, e após a aplicação dos questionários entre as áreas envolvidas no PDP; efetuar conversas informais buscando verificar o alinhamento dos conceitos entre a hierarquia na empresa e também buscar esclarecer dúvidas quanto às respostas dos questionários aplicados; 
- Observação direta: a interação direta entre o pesquisador e os envolvidos no PDP ocorre por meio de visitas às áreas envolvidas na condução do PDP e acompanhamento da condução de projetos de novos produtos, por meio de participação em reuniões de desenvolvimento. É importante verificar se o que está documentado no PDP realmente acontece na prática pelas áreas envolvidas com o PDP.

De acordo com Croom (2005), o uso de diversas fontes de evidência permite a utilização da técnica de triangulação, que compreende uma interação entre diversas fontes de evidência para sustentar os constructos, proposições ou hipóteses, visando analisar a convergência das fontes de evidência. Este trabalho de característica exploratória busca elaborar proposições sobre o tema, por meio da análise da relação das variáveis encontradas na literatura e constatadas no estudo de caso, que influenciam no desempenho da fase de projeto do processo no PDP.

Este trabalho objetiva o uso da técnica de triangulação, portanto contempla a utilização de várias fontes de evidência, que são aplicadas a diferentes níveis da estrutura organizacional das unidades de análise pesquisadas para se obter maior rigor na análise dos dados. Após escolhido os métodos e técnicas de pesquisa, e justificado suas escolhas, são descritos na próxima seção as etapas para realização do teste piloto na Planta-1.

\subsubsection{Investigação empírica: conduzir teste piloto}

O objetivo do teste piloto na Planta-1 é verificar os procedimentos de aplicação com base no protocolo elaborado, visando seu aprimoramento. A partir dessa aplicação, têm-se também condições de verificar a qualidade dos dados obtidos, visando identificar se eles estão associados aos constructos, e conseqüentemente, se contribuem para o atendimento aos objetivos da pesquisa (VOSS et al., 2002). A partir do teste piloto fazem-se então as correções e ajustes necessários (YIN, 2001). De acordo com o protocolo elaborado, a condução do teste piloto segue as etapas destacadas na figura 19. 


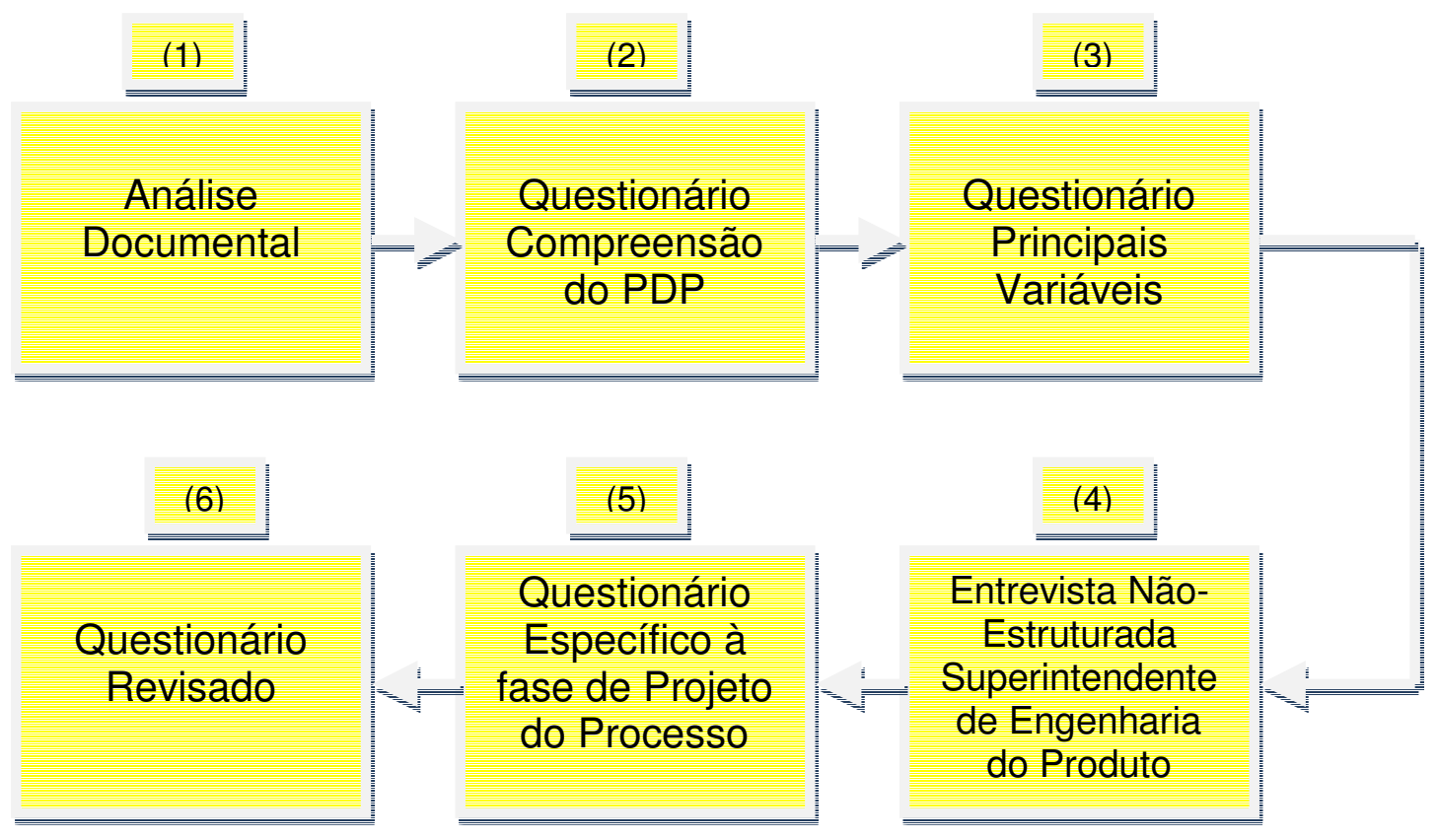

Figura 19 - Etapas de condução do teste piloto.

Fonte: Elaborado pelo autor.

As etapas indicadas na figura 19 são detalhadas a seguir:

1. Análise documental dos procedimentos operacionais relacionados ao PDP, como relatórios executivos que contém o status dos projetos em andamento, atas de reuniões e documentos complementares em conformidade com a ISO TS 16949 (2002), que estabelece os procedimentos a serem adotados no PDP, bem como as responsabilidades em cada etapa desses eventos. Os principais documentos complementares utilizados neste trabalho estão ilustrados a seguir na tabela 16.

Tabela 16 - Principais documentos complementares utilizados na análise documental.

\begin{tabular}{l|l}
\hline \multicolumn{1}{c|}{ DOCUMENTO } & \multicolumn{1}{c}{ OBJETIVO } \\
\hline \hline $\begin{array}{l}\text { Manual e requisitos do } \\
\text { sistema da qualidade }\end{array}$ & $\begin{array}{l}\text { Estabelece as atribuições e princípios básicos para funcionamento } \\
\text { do sistema de gestão da qualidade, aplicados para a fabricação de } \\
\text { placas de aço, bobinas e chapas laminadas. }\end{array}$ \\
\hline $\begin{array}{l}\text { Norma de } \\
\text { desenvolvimento de } \\
\text { produto }\end{array}$ & $\begin{array}{l}\text { Estabelece os procedimentos a serem adotados no PDP e em } \\
\text { outros experimentos integrados que visem à melhoria de } \\
\text { desempenho do produto ou adequação ao uso, bem como as } \\
\text { responsabilidades em cada etapa desses eventos. }\end{array}$ \\
\hline $\begin{array}{l}\text { Norma de consulta de } \\
\text { produto não padronizado }\end{array}$ & $\begin{array}{l}\text { Analisa objetivamente as solicitações do cliente referentes a } \\
\text { produtos não padronizados, visando aprimorar a qualidade, o prazo } \\
\text { de resposta e a especificação correta dos parâmetros de } \\
\text { fabricação. }\end{array}$ \\
\hline
\end{tabular}

Fonte: Elaborado pelo autor com base na análise documental nas unidades de análise. 
Tabela 16 - Principais documentos complementares utilizados na análise documental - Continuação.

\begin{tabular}{l|l}
\hline \multicolumn{1}{c|}{ DOCUMENTO } & \multicolumn{1}{c}{ OBJETIVO } \\
\hline \hline $\begin{array}{l}\text { Norma de laminação } \\
\text { controlada }\end{array}$ & $\begin{array}{l}\text { Estabelece os parâmetros de laminação que devem ser seguidos } \\
\text { durante a laminação controlada de produtos, em espessuras, tendo } \\
\text { como objetivo a obtenção de características de resistência } \\
\text { mecânica e tenacidade superior as obtidas via laminação } \\
\text { convencional. }\end{array}$ \\
\hline $\begin{array}{l}\text { Norma de gerenciamento } \\
\text { de produto }\end{array}$ & $\begin{array}{l}\text { Estabelece o procedimento para elaboração de normas de produto, } \\
\text { objetivando uniformidade na apresentação, programação, redação, } \\
\text { numeração, processamento, aprovação, implantação, distribuição, } \\
\text { auditoria e revisão. }\end{array}$ \\
\hline $\begin{array}{l}\text { Política de especificação } \\
\text { de produto }\end{array}$ & $\begin{array}{l}\text { Define os parâmetros de especificação para atender os requisitos } \\
\text { de qualidade dos pedidos e o bom desempenho do produto nos } \\
\text { clientes. }\end{array}$ \\
\hline Registros da qualidade & $\begin{array}{l}\text { Documentos que mostram a evidência objetiva da execução de } \\
\text { determinados procedimentos do sistema da qualidade nos diversos } \\
\text { processos da empresa. }\end{array}$ \\
\hline
\end{tabular}

Fonte: Elaborado pelo autor com base na análise documental nas unidades de análise.

Além disso, também foi utilizado um questionário que a Planta-1 do teste piloto respondeu à Pesquisa de Inovação Tecnológica (PINTEC). Esta pesquisa foi realizada em 2005 pelo Instituto Brasileiro de Geografia e Estatística (IBGE) com o propósito de obter informações sobre as atividades de inovação no desenvolvimento de produto e processo no setor industrial brasileiro, mostrando os projetos realizados, os gastos com inovação e os tipos de inovação realizados pelo setor siderúrgico.

2. Elaboração e aplicação de um questionário mostrado (Apêndice $B$ ) à área de engenharia do produto para compreensão do PDP, baseado na estrutura referencial composta por seis dimensões de Clark e Wheelwright (1992): definição de projeto; organização de projeto e de pessoal envolvido; liderança e gerenciamento de projeto; resolução de problemas, testes e protótipos; revisões gerenciais e controle, e alterações de projeto. Este questionário foi enviado via email ao responsável pela condução da fase de projeto do processo, que repassou à sua equipe de engenheiros para que respondessem em grupo, e não foi comunicado, nem percebido pelo autor dificuldades no entendimento das questões, que retornaram via e-mail. No entanto, após leitura das respostas foram realizadas conversas informais com os engenheiros que participaram da elaboração das respostas do questionário para melhor entendimento do PDP;

3. Adaptação da tabela 8 , citada no Capítulo 2 do referencial teórico, das principais variáveis encontradas na revisão da literatura, sendo primeiramente utilizada 
para avaliação do grau de importância de cada variável do PDP, conforme ilustra o Apêndice $C$ e, em seguida, aplicado às áreas envolvidas no PDP. Esta tabela foi respondida por três analistas (engenheiros), sendo um de cada área envolvida no PDP (marketing, engenharia do produto e manufatura) da unidade de análise. É importante salientar que junto à tabela foi enviado um resumo dos conceitos teóricos das 32 variáveis, identificadas na literatura para facilitar na compreensão e avaliação por parte dos respondentes;

4. Realização de uma entrevista não-estruturada, conforme roteiro de entrevista apresentado no Apêndice $D$, com o superintendente de engenharia do produto, que é responsável pela fase de projeto do processo no PDP da unidade de análise, com duração de aproximadamente duas horas, buscando mais informações e esclarecimentos sobre a estruturação e gestão do PDP. Nesta entrevista obteve-se informações complementares importantes ao entendimento do PDP e verifica-se também que há um alinhamento dos conceitos entre a hierarquia na empresa;

5. Elaboração de um questionário específico (após essa coleta inicial de dados) mostrado no Apêndice $E$ para entender a fase de projeto do processo e suas variáveis. Foi considerado para elaboração deste questionário: a análise documental apontada anteriormente, incluindo o questionário do PINTEC; 0 questionário para compreensão do PDP (Apêndice B); as variáveis do referencial teórico avaliadas como mais importantes pelas áreas de marketing, engenharia do produto e manufatura (Apêndice $\mathrm{C}$ ); e as informações obtidas por meio de entrevista não-estruturada com o superintendente de engenharia de produto. Este questionário específico foi aplicado às áreas envolvidas no PDP;

6. Revisar o questionário específico para ser aplicado à outra unidade de análise.

Concluída a fase de investigação empírica, a próxima macro fase é a comparação das unidades de análise, que engloba o estudo de caso único incorporado, escolha das unidades de análise, e a coleta e analise dos dados, estes tópicos são detalhados a seguir. 


\subsubsection{Comparação das unidades de análise: estudo de caso único incorporado}

Conforme mostrado na figura 18 deste capítulo, a primeira etapa da macro fase, comparação das unidades de análise, baseia-se no estudo de caso único incorporado, que é apropriado para o presente trabalho, devido a organização estudada possuir duas unidades de análise (YIN, 2001).

Deste modo, este trabalho apesar de ser entendido como caso único, tem duas unidades de análise, pois, segundo Yin (2001), a utilização de mais de uma unidade de análise proporciona evidências inseridas em diferentes contextos, concorrendo para a elaboração de uma pesquisa de melhor qualidade, em termos de quantidade de dados para análise e embasamento dos resultados. Para Souza (2005), a adoção de estudo de caso único deve ser feita com cuidado, pois tem-se um menor grau de generalização dos resultados. Porém, espera-se uma profundidade maior na avaliação do caso, além de consumir menos recursos.

Assim, será tratado um caso único com duas unidades de análise, devido principalmente a dificuldade de acesso as informações do setor siderúrgico e tempo disponível. Logo, o caso está dividido em um teste piloto na Planta-1, visando aprimorar o protocolo de pesquisa e mais uma unidade de análise designada Planta-

2 no setor siderúrgico brasileiro de aços planos. As unidades de análise fazem parte de uma mesma organização e foram escolhidas baseadas nos seguintes critérios:

- Facilidade no acesso as informações;

- Importância no segmento de aços planos, em termos de produção;

- Possuírem certificações de qualidade e, conseqüentemente, terem o PDP estruturado e documentado;

- Localização em diferentes estados do Brasil, para dar mais subsídios na generalização das práticas da fase de projeto do processo no PDP.

O teste piloto na Planta-1 é realizado em Cubatão-SP, e a Planta-2 fica em Ipatinga-MG. As duas unidades de análise foram selecionadas por se enquadrarem em todas as características citadas anteriormente.

Destaca-se que, após o teste piloto, é realizado ajustes nos instrumentos de coleta e análise de dados, para descobrir se as entrevistas e os questionários foram aplicados de maneira clara, se houve problemas de entendimento e se o protocolo é 
realmente executável. Logo após, a condução da análise na Planta-2 é realizada uma revisão dos dados coletados no teste piloto Planta-1, para análise e comparação com a Planta-2 e respectivamente com a literatura sobre o assunto.

Após a justificativa da escolha das unidades de análise, a próxima seção descreve como deve ser feita a coleta dos dados nas unidades de análise.

\subsubsection{Comparação das unidades de análise: coletar os dados}

Neste trabalho utiliza-se de forma conjunta quatro instrumentos para coleta de dados: análise documental, questionários, entrevista não-estruturada e observação direta. Buscando dados mediante diversos instrumentos, consegue-se garantir a qualidade dos resultados obtidos e torna possível conferir validade ao estudo, evitando que ele fique subordinado à subjetividade do pesquisador ( $Y I N, 2001)$. A tabela 17 detalha como foram aplicados os instrumentos de coleta de dados nas unidades de análise.

Tabela 17 - Aplicação dos instrumentos de coleta de dados nas unidades de análise.

\begin{tabular}{|c|c|}
\hline INSTRUMENTOS & APLICAÇÃO NA COLETA DE DADOS \\
\hline Análise documental & $\begin{array}{ll}\text { - } & \text { Procedimentos operacionais } \\
\text { - } & \text { Relatórios executivos que contém o status dos } \\
\text { - } & \text { Atajetos em andamento } \\
\text { - } & \text { Docuniões } \\
\text { - } & \text { Questionário do PINTEC } \\
\end{array}$ \\
\hline Questionário & $\begin{array}{l}\text { - Compreensão do PDP (Apêndice B), aplicado ao } \\
\text { responsável pela área de engenharia do produto } \\
\text { - } \text { Principais variáveis (Apêndice C), aplicado aos } \\
\text { engenheiros envolvidos com o PDP das áreas de } \\
\text { marketing, engenharia do produto e manufatura. } \\
\text { Enviado junto com a tabela um resumo dos } \\
\text { conceitos teóricos das } 32 \text { variáveis, para facilitar na } \\
\text { compreensão dos respondentes } \\
\text { Específico à fase de projeto do processo (Apêndice } \\
\text { E), aplicado aos engenheiros envolvidos com o PDP } \\
\text { das áreas de marketing, engenharia do produto e } \\
\text { manufatura }\end{array}$ \\
\hline Entrevistas & $\begin{array}{l}\text { - Não-estruturada (Apêndice D); } \\
\text { Com o Superintendente de Engenharia do Produto }\end{array}$ \\
\hline $\begin{array}{l}\text { Observação em reuniões e visitas } \\
\text { às áreas envolvidas no PDP }\end{array}$ & - $\quad$ Direta \\
\hline
\end{tabular}


Após a realização do teste piloto e ajustes no protocolo de pesquisa, a etapa de coleta de dados na Planta-2 inicia com o contato via telefone, procurando situar o responsável pelo PDP da unidade de análise quanto aos objetivos da pesquisa para, em seguida, enviar os questionários via e-mail. Estes questionários devem ser distribuídos pelo responsável do PDP às áreas envolvidas no PDP (marketing, engenharia do produto e manufatura). Depois de recebidas as respostas dos questionários e analisada as informações, é realizada uma visita à unidade de análise para realizar a análise documental e aplicar a entrevista não-estruturada com o superintendente de engenharia de produto, que busca verificar o alinhamento dos conceitos entre a hierarquia na empresa e esclarecer dúvidas.

Finalizando a coleta de dados, o próximo assunto é como deve ser tratada a análise destes dados coletados.

\subsubsection{Comparação das unidades de análise: analisar os dados}

Após coletar os dados de diferentes fontes de evidência, o pesquisador deve produzir uma narrativa geral das unidades de análise, considerando que é necessário fazer uma redução dos dados de tal forma que seja incluído na análise apenas o essencial e que está relacionado aos objetivos e constructos da pesquisa (MIGUEL, 2007).

No presente trabalho, pretende-se por meio da análise cruzada das unidades de análise e triangulação das informações coletadas identificar convergência e divergência entre as evidências e em paralelo checar os resultados com a literatura.

Também é importante após a transcrição da narrativa, enviá-la aos respondentes para fazerem uma revisão do texto e definir o que pode ser divulgado no trabalho e, em seguida, montar um painel demonstrativo para facilitar na comparação dos dados e extrair as conclusões.

Finalizando, o presente capítulo, a próxima etapa consiste na macro fase comparação das unidades de análise, no qual são apresentados os resultados empíricos das Planta-1 e Planta-2, que englobam as etapas de coleta e análise dos dados, além da comparação das unidades de análise em relação à literatura sobre o tema. 


\section{ESTUDO DE CASO - DESCRIÇÃO E RESULTADOS}

Este capítulo apresenta os resultados empíricos do presente estudo, e busca demonstrar uma análise dos dados coletados no teste piloto (Planta-1) e também na outra unidade de análise (Planta-2), por meio da aplicação do protocolo de pesquisa. Nesse sentido, o capítulo é dividido em três seções. A primeira seção busca fazer uma caracterização geral da organização e das unidades de análise selecionadas, descrevendo a importância das mesmas e a relação com o PDP. Em seguida, por meio das seis dimensões de Clark e Wheelwright (1992) é demonstrado como está estruturado o PDP nas duas unidades de análise. O capítulo finaliza com a análise da fase de projeto de processo, sintetizando os resultados da entrevista e questionários, e buscando fazer uma análise da fase de projeto do processo das unidades de análise a luz do referencial teórico deste trabalho.

\subsection{Seleção e caracterização das unidades de análise}

As duas unidades de análise fazem parte do maior e um dos mais modernos complexos siderúrgicos de aços planos da América Latina, formado por 16 empresas de negócios em setores estratégicos, dentro e fora do Brasil, tais como: siderurgia, logística, estamparia e bens de capital, distribuição e serviços. A organização tem capacidade para produzir 9,5 milhões de toneladas de aço por ano, o que representa $28 \%$ da produção brasileira, é o $29^{\circ}$ maior grupo do mundo na área de siderurgia.

Além disso, dispõe de uma linha completa de produtos planos, e as unidades de análise detêm juntas $52 \%$ de participação no mercado interno de laminados planos. Estas mantêm a liderança nos principais segmentos, com destaque para a participação nos setores que consomem produtos de maior valor agregado, tais como: automobilístico $(59,0 \%)$, autopeças $(62,1 \%)$, máquinas agrícolas e rodoviárias $(95,7 \%)$, equipamentos industriais $(99,7 \%)$, equipamentos eletrônicos $(64,8 \%)$ e tubos de grande diâmetro $(98,0 \%)$. A tabela 18 mostra a demanda do mercado interno por produtos laminados planos e a participação das unidades de análise por setor. 
Tabela 18 - Participação das unidades de análise no mercado interno de produtos laminados planos.

\begin{tabular}{l|c|c|c}
\hline \multicolumn{1}{c|}{ SETOR } & $\begin{array}{c}\text { DEMANDA MERCADO } \\
\text { INTERNO DE LAMINADOS } \\
\text { PLANOS }\left(\mathbf{1 0}^{\mathbf{3}} \mathbf{t}\right)\end{array}$ & $\begin{array}{c}\text { VENDAS } \\
\left.\mathbf{( 1 0 ^ { 3 }} \mathbf{t}\right)\end{array}$ & $\begin{array}{c}\text { PARTICIPAÇÃO } \\
\text { (\%) EM 2006 }\end{array}$ \\
\hline \hline Naval & 34 & 34,2 & 100,0 \\
\hline Equipamentos Industriais & 235 & 234,7 & 99,7 \\
\hline Tubos de Grande Diâmetro & 327 & 320,2 & 98,0 \\
\hline Perfis & 167 & 163,1 & 97,7 \\
\hline Máquinas Agrícolas e Rodoviárias & 198 & 189,4 & 95,7 \\
\hline Outros & 174 & 119,3 & 68,1 \\
\hline Equipamentos Eletrônicos & 374 & 242,3 & 64,8 \\
\hline Autopeças & 1.527 & 948,6 & 62,1 \\
\hline Automobilístico & 1.150 & 677,8 & 59,0 \\
\hline Tubos de Pequeno Diâmetro & 784 & 423,7 & 54,1 \\
\hline Distribuição & 2.863 & $1.211,7$ & 42,3 \\
\hline Construção Civil & 787 & 310,8 & 39,5 \\
\hline Utilidades Domésticas & 325 & 121,9 & 37,5 \\
\hline Relaminação & 287 & 52,3 & 18,2 \\
\hline Recipientes & 670 & 86,0 & 12,8 \\
\hline Total & $\mathbf{9 . 9 0 2}$ & $\mathbf{5 . 1 3 6 , 0}$ & $\mathbf{5 1 , 9}$ \\
\hline Fonte: Elaborado pelo autor & & \\
\hline
\end{tabular}

Fonte: Elaborado pelo autor com base no relatório anual (interno) de 2006 das unidades de análise.

As duas unidades de análise receberam juntas investimentos de US\$ 3 bilhões na última década, visando seu aprimoramento tecnológico. A Planta-1, em Cubatão, no litoral do Estado de São Paulo, tem capacidade instalada para produzir 4,5 milhões de toneladas de aço líquido por ano e está estrategicamente localizada próxima ao maior centro consumidor do país. A Planta-2 tem capacidade para produzir 5,0 milhões de toneladas de aço líquido por ano e está instalada na cidade de Ipatinga, a $217 \mathrm{~km}$ de Belo Horizonte, no Vale do Aço, próxima a uma das maiores reservas de minério de ferro do mundo, o Quadrilátero Ferrífero.

A escolha das unidades de análise se justifica devido ao seu critério de certificações de qualidade, o qual proporciona um PDP estruturado e documentado de acordo com as exigências das normas de qualidade, como na ISO TS 16949 (2002), no qual os requisitos do elemento 7.3 da norma incluem o projeto e desenvolvimento de produto e de processo. Somando-se a isso, as unidades de análise preocupam-se com a inovação tecnológica do setor e participam de vários projetos de inovação tecnológica, como do consórcio denominado projeto Ultra Light Steel Auto Body (ULSAB), que comissionou a Porsche Engineering Services, Inc. (PES) para conduzir um estudo a fim de determinar se uma carroceria substancialmente leve, feita de aço, poderia ser projetada. Em continuação ao programa ULSAB, foi criado um projeto para desenvolver painéis de cobertura, que, 
além de mais leves, fossem estruturalmente otimizados e passíveis de fabricação a custos competitivos, dando origem ao projeto Ultra Light Steel Auto Closures (ULSAC).

Além disso, as unidades de análise possuem um Centro de Pesquisa e Desenvolvimento (P\&D), sendo um dos maiores da América Latina. Até o ano de 2006, o Centro de P\&D depositou 615 pedidos de patentes no Instituto Nacional de Propriedade Industrial (INPI) e 51 no exterior, que resultaram em 413 cartas patentes relativas a inovações no processo de produção de aço, sendo 390 no Brasil e 23 no exterior. O Centro de P\&D é responsável por absorver, gerar e disseminar conhecimentos científicos e tecnológicos voltados, sobretudo, para: caracterização e avaliação dos processos de produção do aço; melhoria e desenvolvimento de processos e produtos; redução de custos; engenharia de aplicação de produtos; e exploração de novas tecnologias e novos negócios. Com base no relatório anual (interno) de 2006 das unidades de análise, na área de pesquisa, 140 profissionais trabalharam em 484 estudos desenvolvidos, exigindo investimentos de $R \$ 23,2$ milhões. Os esforços se concentraram, especialmente, na melhoria de processo e na redução de custos, na otimização operacional e na avaliação do comportamento metalúrgico dos aços. Na pesquisa de produtos, destaca-se o desenvolvimento de aços avançados de alta resistência para o setor automotivo e de aços para o setor naval e offshore. Referente a distribuição dos investimentos no Centro de P\&D, percebe-se uma concentração em atividades tecnológicas voltadas ao desenvolvimento de produto $(42,1 \%)$ e de processo $(50,2 \%)$. Assim, estes dados afirmam que existe uma demanda por inovações tecnológicas em produto para 0 segmento de aços planos, ainda que de natureza incremental, pelo setor automotivo, que representa $(68,5 \%)$ dos investimentos.

Quanto ao desenvolvimento de novos produtos e processos, as unidades de análise tiveram melhoria de desempenho e desenvolvimento de aços galvanizados para construção civil, eletrodomésticos e setor automotivo. Também desenvolveu aços de alta resistência, novos aços "Dual Phase" como laminados a frio e revestidos, estes aços são capazes de atender exigências de segurança, redução de peso, e consumo de emissões de gases, além de aços certificados pelo American Petroleum Institute $(A P I)$ para produção de gasodutos e oleodutos à indústria petrolífera. 
As unidades de análise também têm contratos de cooperação técnica com centros de pesquisa e com siderúrgicas do Japão, tendo conquistado certificações importantes como a ISO 9001 (2000), selo Japanese Industrial Standard (JIS), fornecido pelo Ministério da Indústria do Japão para empresas que utilizam o controle estatístico e a sistemática da garantia da qualidade para chapas grossas, ISO TS 16949 (2002) - esse certificado da indústria automobilística e ISO 14001 (2004), que corresponde às práticas de gestão do meio ambiente, além do Q1 Ford, que habilitou as unidades de análise a ser fornecedor mundial da Ford.

Outros motivos de destaque das duas unidades de análise, com base em 2006 (além da facilidade no acesso as informações devido ao pesquisador trabalhar no setor siderúrgico), são: investimentos de $\mathrm{R} \$ 487,1$ milhões com inovação tecnológica; geração de 13.720 empregos diretos e aproximadamente 30.000 indiretos e uma receita líquida consolidada de $R \$ 12,4$ bilhões. Assim, justifica-se a importância destas duas unidades de análise no contexto industrial do estado de São Paulo, Minas Gerais e do país. A tabela 19 sintetiza os principais valores citados acima e acrescenta mais algumas informações das duas unidades de análise.

Tabela 19 - Síntese dos principais indicadores das unidades de análise selecionadas para pesquisa.

\begin{tabular}{l|c|c}
\hline \multicolumn{1}{c|}{ EMPRESAS } & PLANTA-1 & PLANTA-2 \\
\hline \hline Produção de aço bruto & 4.200 mil t/ano & 4.600 mil t/ano \\
\hline Empregados & 5.646 & 8.074 \\
\hline Receita Líquida & $\mathrm{R} \$ 5.018$ milhões & $\mathrm{R} \$ 6.790$ milhões \\
\hline & $\mathrm{R} \$ 229,3$ milhões & $\frac{\mathrm{R} \$ 257,8 \text { milhões }}{\text { Energia elétrica }}$ \\
& Atualização tecnológica & $\mathrm{R} \$ 55,4$ milhões \\
& $\mathrm{R} \$ 151,4$ milhões & Atualização tecnológica \\
Investimentos & Proteção ambiental & $\mathrm{R} \$ 29,7$ milhões \\
& $\mathrm{R} \$ 34,4$ milhões & Outros \\
& $\mathrm{R} \$ 43,5$ milhões & $\mathrm{R} \$ 20,7$ milhões \\
& & Proteção ambiental \\
& & $\mathrm{R} \$ 55,6$ milhões \\
& & Outros \\
& & $\mathrm{R} \$ 96,4$ milhões \\
\hline
\end{tabular}

Estrutura Produtiva Integrada a coque

Fonte: Elaborado pelo autor com base no relatório anual (interno) de 2006 das unidades de análise. 
Tabela 19 - Síntese dos principais indicadores das unidades de análise selecionadas para pesquisa Continuação.

\begin{tabular}{|c|c|c|}
\hline EMPRESAS & PLANTA-1 & PLANTA-2 \\
\hline Principais Linhas de Produtos & $\begin{array}{l}\text { Planos comuns } \\
\text { Placas, Chapas grossas, } \\
\text { Laminados a quente e a frio }\end{array}$ & $\begin{array}{l}\text { Chapas grossas, Laminados } \\
\text { a quente e a frio e } \\
\text { Galvanizados }\end{array}$ \\
\hline Ações no Capital Votante & \multicolumn{2}{|c|}{$\begin{array}{c}\text { 63,9\% das ações ordinárias } \\
\text { Grupo Nippon } 24,7 \% \text {, Caixa dos Empregados da Usiminas } \\
10,1 \% \text {, Grupo Votorantim/Camargo Correa } 23,2 \% \text { e } \\
\text { Companhia Vale do Rio Doce } 5,9 \%\end{array}$} \\
\hline Gastos com P\&D/Faturamento $^{20}$ & $0,01 \%$ & $0,01 \%$ \\
\hline $\begin{array}{l}\text { Pesquisa de Satisfação dos } \\
\text { Clientes }\end{array}$ & $83,6 \%$ & $85,2 \%$ \\
\hline
\end{tabular}

Fonte: Elaborado pelo autor com base no relatório anual (interno) de 2006 das unidades de análise.

As unidades de análise selecionadas comercializam aços planos em diversas formas e subprodutos gerados nos processos de produção, como carboquímicos e resíduos. Os processos relativos à realização dos produtos estão diretamente ligados ao atendimento das necessidades e expectativas dos clientes. O processo de fabricação de aços planos das unidades de análise é dividido em macro áreas detalhado no (Anexo A): Redução; Aciaria; Laminação a Quente; Laminação a Frio; Linha de Galvanização na Planta-2; e Apoio. A tabela 20 resume a função de cada área de manufatura no processo de fabricação de aços planos.

Tabela 20 - Principais áreas envolvidas no processo de fabricação de aços planos.

\begin{tabular}{l|l}
\hline \multicolumn{1}{c|}{ MANUFATURA } & \multicolumn{1}{c}{ ATIVIDADES DE PRODUÇÃO } \\
\hline \hline \multirow{2}{*}{ Área de Redução } & $\begin{array}{l}\text { O minério de ferro e os fundentes são aglomerados e transformados em } \\
\text { sínter para utilização como carga metálica, e o coque é utilizado como } \\
\text { principal combustível nos altos fornos. A partir do coque e da carga metálica, } \\
\text { gera-se o ferro gusa que, em seguida, é submetido ao processo de pré- } \\
\text { tratamento e transportado para a aciaria em carros torpedo, finalizando-se o } \\
\text { processo de redução. }\end{array}$ \\
\hline Área de Aciaria & $\begin{array}{l}\text { O gusa passa pelo refino primário, e no conversor se transforma em aço } \\
\text { líquido, gerando também as escórias. O aço líquido pode passar ainda por } \\
\text { um refino secundário, para ajuste da temperatura, composição química e } \\
\text { limpidez. Ao final do processo de refino, o aço líquido é vazado nas } \\
\text { máquinas de lingotamento contínuo para solidificação e transformação em } \\
\text { placas, estas posteriormente são cortadas, inspecionadas e identificadas. }\end{array}$ \\
\hline
\end{tabular}

Fonte: Elaborado pelo autor com base nas práticas das unidades de análise.

${ }^{20}$ Para quantificar os gastos com P\&D, foram utilizados para Planta-1 valores baseados nas respostas da pesquisa do PINTEC, e no da Planta-2 foram considerados os investimentos realizados pelo Centro de $P \& D$. 
Tabela 20 - Principais áreas envolvidas no processo de fabricação de aços planos - Continuação.

\section{MANUFATURA}

Área de Laminação a Quente
ATIVIDADES DE PRODUCÃO

As placas de aço são reaquecidas e laminadas em chapas ou tiras a quente. Após a laminação, as chapas ou tiras a quente seguem para a linha de acabamento e são cortadas, identificadas e rebobinadas, e geram os produtos chapas grossas, tiras a quente e bobinas. Também pode ocorrer tratamento térmico e ensaios de ultra-som.

As bobinas recebidas são inicialmente processadas na decapagem para remoção da camada de óxido formada sobre a superfície metálica. Depois podem ser cortadas em chapas finas a quente decapadas; podem ser enviadas para o cliente ou podem ser laminadas a frio. $\mathrm{Na}$ etapa seguinte, uma parte do material é processada na limpeza que remove os resíduos oleosos da emulsão usada no laminador a frio. A partir daí, todo material processado na limpeza passa por um tratamento térmico de recozimento, que altera a estrutura cristalina do aço, tornando-o mais macio e com melhor capacidade para deformação. Concluída essa etapa, o produto passa pelo laminador de encruamento, processo que define a rugosidade na superfície da chapa e ajusta as propriedades mecânicas do aço. Na etapa final, as bobinas podem ser destinadas às linhas de rebobinamento, à galvanização eletrolítica (Planta-2) ou para tesoura onde são geradas chapas finas.

O processo de eletrogalvanização e por imersão a quente na Planta-2 tem como objetivo depositar uma fina camada de zinco metálico na superfície das tiras utilizadas como matérias-primas. A presença de zinco sobre o aço aumenta consideravelmente a resistência à corrosão.

Para operar adequadamente os processos relativos à realização do produto, é preciso suporte dos processos que reúnem as atividades relacionadas à compra e gestão de materiais e fornecedores, planejamento e programação da produção, transporte, energia, utilidades, tecnologia de informações, automação, calibração, P\&D, estudos de engenharia industrial e serviços de manutenção, através de estudos para melhoria da eficácia organizacional.

Fonte: Elaborado pelo autor com base nas práticas das unidades de análise.

A seguir, é demonstrado como está estruturado o PDP das unidades de análise, baseado nas seis dimensões da estrutura referencial proposta por Clark e Wheelwright (1992), apresentada no Capítulo 2. A organização possui uma administração geral unificada, em função da integração de seus sistemas de planejamento e controle da produção e de gestão integrada, que servem às áreas administrativas e de apoio.

Assim, enfatiza-se que o PDP das duas unidades de análise está padronizado desde 2005, e conseqüentemente, alguns dados apresentados na descrição sobre a estrutura do PDP são os mesmos para as duas unidades de análise, como por exemplo: a análise baseada nas seis dimensões de Clark e Wheelwright (1992), a estrutura organizacional, o fluxo do PDP e os deliverables de passagem de fase no PDP. 


\subsection{Descrição sobre a estrutura do PDP das unidades de análise}

Para compreensão da estrutura do PDP das unidades de análise, iniciou-se o estudo pela análise de procedimentos operacionais, relatórios executivos que contém o status dos projetos em andamento, atas de reuniões, documentos complementares do PDP e tomadas de notas durante o contato com as pessoas envolvidas no PDP. Em seguida, aplicou-se o questionário mostrado no Apêndice $B$ para área de engenharia do produto visando uma compreensão do PDP, baseado em uma estrutura referencial composta por seis dimensões propostas por Clark e Wheelwright (1992): a definição de projeto; a organização de projeto e de pessoal envolvido; a liderança e gerenciamento de projeto; a resolução de problemas, testes e protótipos; as revisões gerenciais e controle; e as alterações de projeto.

A Planta-1 na fase de projeto do processo possui uma área de engenharia de produto que é responsável pela condução desta fase, sendo que a equipe é composta por 16 funcionários, que engloba os cargos de gerente, engenheiros e assistentes técnicos, e tem as seguintes atribuições: coordenar as atividades de assistência técnica a clientes; estudos e projetos de desenvolvimento de novos produtos; atividades de apoio técnico às fábricas, em atendimento às necessidades de capacitação; atualização e inovação tecnológica; geração de novos negócios; e aumento de produtividade.

A Planta-2 possui duas gerências envolvidas na fase de projeto do processo, sendo uma para laminação a quente com 25 funcionários e outra para laminação a frio e revestidos com 33 funcionários, totalizando 58 funcionários, que engloba os mesmos cargos e possuem atribuições similares a equipe da Planta-1, ou seja, de participar dos estudos de viabilidade de produção e comercialização de novos produtos, inclusive daqueles com beneficiamento externo, executando análise técnica de fabricação dos mesmos. A tabela 21 mostra como está distribuído os funcionários envolvidos com a atividade de desenvolvido de novos produtos nas unidades de análise. 
Tabela 21 - Estrutura de funcionários envolvidos no PDP das unidades de análise.

\begin{tabular}{l|c|c}
\hline \multicolumn{1}{c|}{ CAPACITAÇÃO DE FUNCIONÁRIOS } & PLANTA-1 & PLANTA-2 \\
\hline \hline Doutores & 2 & 1 \\
\hline Mestres & 20 & 42 \\
\hline Graduados & 309 & 335 \\
\hline Técnicos de nível médio & 148 & 153 \\
\hline Total & $\mathbf{4 7 9}$ & $\mathbf{5 3 1}$ \\
\hline Fonte: Elaborálise.
\end{tabular}

Fonte: Elaborado pelo autor com base nas informações organizacionais das unidades de análise.

Os principais tipos de projetos desenvolvidos pelas duas unidades de análise ${ }^{21}$ são derivativos ou de melhorias, variando de versões de custo reduzido de um produto existente até projetos de melhoria de um processo de produção existente. Tais projetos geralmente requerem muito menos recursos do que projetos que trazem avanços significativos, conforme descrito no capítulo de referencial teórico. Os principais motivadores das unidades de análise para estes projetos de novos produtos são: a estratégia de atuação no segmento em que o cliente está inserido; a busca de aumento das margens de contribuição; e a evolução tecnológica do produto.

Para controlar o PDP as unidades de análise utilizam-se dos seguintes indicadores de desempenho no processo de desenvolvimento de novos produtos: a análise da lucratividade gerada pelos produtos novos; o tempo gasto em cada fase do desenvolvimento; e o tempo real versus tempo planejado. Também consideram como medidas de sucesso: o nível de desempenho (produção, vendas e retorno financeiro) do produto; as metas de margem do novo produto; as metas de lucratividade do novo produto; e percentual de vendas dos novos produtos na receita total.

Os principais métodos e técnicas de suporte ao PDP utilizados pelas unidades de análise são: análise de mercado; análise de risco e potencial de falhas; análise de viabilidade técnica e econômica; análise de custo de fabricação; Roteiro de Acompanhamento de Experiência (RAE); Análise dos Modos de Falha e seus Efeitos (FMEA), que é realizado para o desenvolvimento de novos produtos destinados a

\footnotetext{
${ }^{21}$ As unidades de análise desenvolvem novos produtos para o segmento de aços planos, conforme o mercado que cada uma está inserida (automobilístico, naval, construção civil, etc.). O Centro de P\&D das unidades de análise busca desenvolver novos produtos para o mercado interno baseado em desenvolvimentos já realizados por siderúrgicas internacionais, que possuem centros de pesquisa mais avançados e que se concentram em desenvolver produtos de inovação radical e projetos de P\&D avançado.
} 
indústria automobilística, e está condicionada à solicitação explícita do cliente ou quando este for signatário da ISO TS 16949 (2002); e técnicas estatísticas (estatística descritiva e inferencial) e metalúrgicas, que são utilizadas em função do assunto que se analisa e conforme a experiência e o conhecimento do responsável pelo desenvolvimento do produto. Quanto as técnicas metalúrgicas, são utilizadas aquelas inerentes ao assunto estudado, podendo ser de metalografia, análise química, difração de raios-x, microssonda, ensaios de tração, ensaios de dureza, ensaios de dobramento, ensaios de embutimento, ensaios de curva limite de conformação, ensaios de impacto, ensaios de temperabilidade, etc. Basicamente, os testes são relacionados a ensaios destrutivos e não destrutivos de aços.

Em 2006 e 2007, a Planta-1 concluiu e lançou no mercado três projetos, sendo um no setor de equipamento industrial e dois no setor de construção civil. No período de 2003 a 2005, a mesma unidade de análise forneceu ao mercado aproximadamente 50 mil toneladas de aço referente a produtos novos, o que representou um faturamento de $R \$ 64,5$ milhões e uma margem bruta de $R \$ 15,5$ milhões.

Já a Planta-2, em 2006 e 2007, concluiu e lançou no mercado seis projetos, sendo dois no setor de equipamento industrial, um no setor automotivo, dois no setor de linha branca e um no setor de construção civil. No período de 2003 a 2005, a unidade de análise forneceu ao mercado aproximadamente 83 mil toneladas de aço referente a produtos novos, que representou um faturamento de $R \$ 165,1$ milhões e uma margem bruta de $R \$ 28,7$ milhões. A tabela 22 apresenta uma síntese dos projetos de desenvolvimentos de novos produtos das unidades de análise.

Tabela 22 - Projetos de desenvolvimento de novos produtos das unidades de análise.

\begin{tabular}{l|c|c}
\hline \multicolumn{1}{c|}{ CLASSIFICAÇÃO/INDICADORES } & PLANTA-1 & PLANTA-2 \\
\hline \hline Projetos de novos produtos Iniciados & 8 & 27 \\
\hline Projetos em Andamento & 3 & 18 \\
\hline Projetos Suspensos & 2 & 3 \\
\hline Projetos Concluídos & 3 & 6 \\
\hline Tempo médio de desenvolvimentos concluídos & 2 anos & 5 anos \\
\hline Faturamento com novos produtos & $\mathrm{R} \$ 64,5$ milhões & $\mathrm{R} \$ 165,1$ milhões \\
\hline Faturamento com novos produtos/ Receita líquida & $0,64 \%$ & $1,21 \%$ \\
\hline
\end{tabular}

Fonte: Elaborado pelo autor com base no Relatório (interno) do PDP das unidades de análise. 
Uma vez comparado os projetos de desenvolvimento de novos produtos, percebe-se que a diferença no tempo de desenvolvimento é devido principalmente ao tipo de projeto desenvolvido por cada unidade de análise e a necessidade do cliente.

Em seguida, partiu-se para entender como se mobiliza a estrutura organizacional e times de desenvolvimento de novos produtos das unidades de análise. A figura 20 representa a estrutura organizacional das duas unidades de análise e destaca os níveis hierárquicos e times formados para conduzir o PDP.

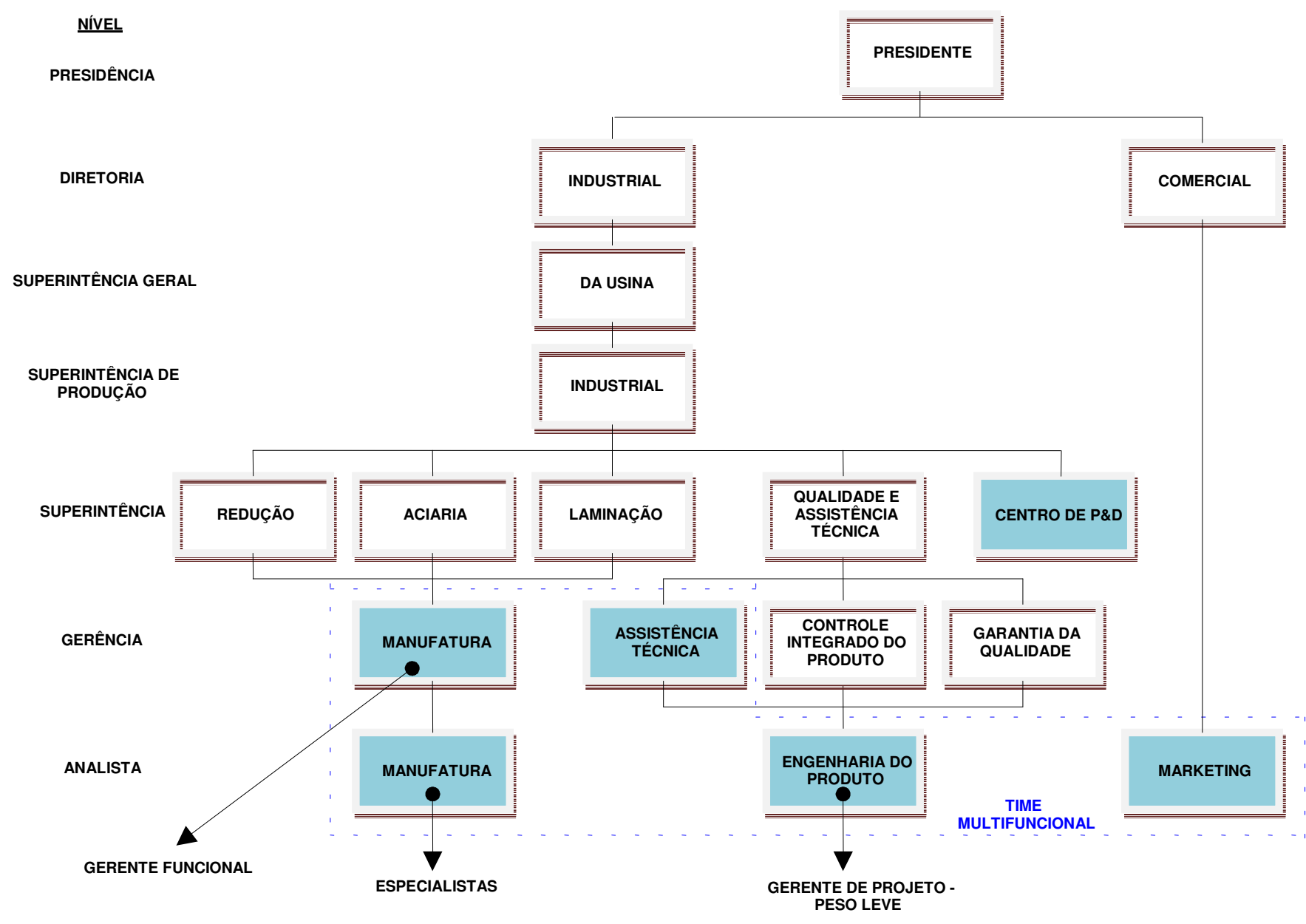

Figura 20 - Estrutura organizacional e times do PDP nas unidades de análise.

Fonte: Elaborado pelo autor.

A seguir, com base na coleta de dados realizada nas duas unidades de análise, são descritas as práticas identificadas baseada na estrutura referencial propostas por Clark e Wheelwright (1992): definição de projeto; organização de projeto e de 
pessoal envolvido; liderança e gerenciamento de projeto; resolução de problemas, testes e protótipos; revisões gerenciais e controle; e as alterações de projeto.

- Definição de Projeto

A área de marketing faz uma reunião com a área de engenharia do produto, para definir a carteira de desenvolvimento de produtos, bem como as prioridades de desenvolvimento para 0 próximo período ${ }^{22}$. Os projetos ao longo do desenvolvimento podem ser suspensos ou cancelados. Os projetos são suspensos devido a problemas técnicos de aplicação no cliente ou defeitos detectados no desenvolvimento do experimento. No caso de projetos cancelados, pode ocorrer pela solicitação do cliente, devido ao tempo de desenvolvimento e também pela limitação tecnológica dos equipamentos das unidades de análise. As entradas de projetos são geralmente variadas: solicitações de clientes; informações sobre concorrentes; análise de mercado; recomendações de relatórios de pesquisa e informações da bibliografia. Porém, as entradas de projetos, no período 2006 a 2007, concentraram-se 100\% na análise de mercado, feita pela área de marketing, indicando as tendências na utilização de novos produtos, visando sustentar ou adquirir vantagem competitiva. A entrada de projetos pela análise de mercado é considerada pela área de marketing como melhor para as unidades de análise, pois dessa forma consegue-se planejar as idéias e dar prioridade ao desenvolvimento de novos produtos a clientes estratégicos.

Os projetos de desenvolvimento de produto contemplam o enobrecimento de produtos para o mercado interno e exportação crescente de semi-acabados. O termo enobrecimento de produtos no setor siderúrgico é caracterizado por produtos com maior valor agregado, ou seja, produtos que passam por mais etapas de acabamento, como por exemplo os laminados a frio, que são produzidos a partir dos produtos acabados do processo anterior de laminação a quente. Além disso, são caracterizados aços nobres alguns que recebem adição de elementos microligantes para alterar as propriedades mecânicas de acordo com os tipos de aplicações exigidas; e os aços com aplicação de revestimento protetor contra corrosão (galvanização), no qual o mais usado é aquele com zinco e pode ser obtido pelo

\footnotetext{
${ }^{22}$ Antes do inicio do PDP, existe uma etapa denominada de gestão das oportunidades e idéias, no qual, se necessário, acontece uma solicitação de desenvolvimento de novo produto por transferência de tecnologia entre as unidades de análise. Se uma planta já tem um produto desenvolvido na sua carteira e não é desenvolvido pela outra, e surge esta necessidade, é realizado um desenvolvimento de produto por transferência de tecnologia.
} 
processo de imersão a quente e eletrolítico (MOURÃO, 2007). Destaca-se que os produtos com maior valor agregado geram uma maior margem de contribuição.

Os projetos de desenvolvimento de novos produtos são balanceados de acordo com a estratégia de competitividade da organização, buscando atender a demanda do mercado. A figura 21 ilustra como estão distribuídos os projetos das unidades de análise por área de negócios.

PLANTA 1

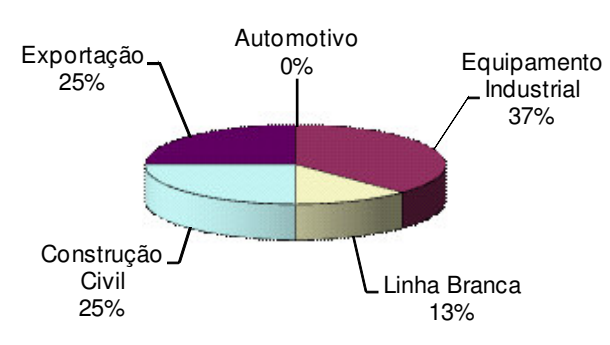

PLANTA 2

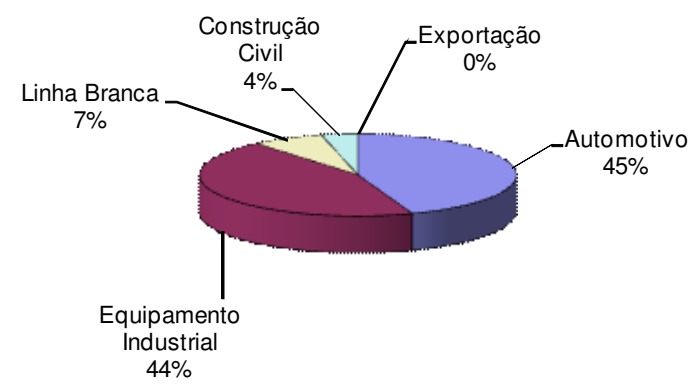

Figura 21 - Distribuição de projetos por área de negócios nas unidades de análise em 2006-2007.

Fonte: Elaborado pelo autor com base no relatório (interno) do PDP das unidades de análise.

A figura 21 ilustra a estratégia de mercado da organização, no qual a Planta-1 fornece produtos semi-acabados tais como: placas para exportação e chapas grossas para o setor naval, equipamentos industriais, e construção civil, no mercado interno, enquanto a Planta-2 fornece chapas grossas para tubos de grande diâmetro e produtos laminados a frio e galvanizados para o setor automotivo e de autopeças. Assim, a organização que engloba as duas unidades de análise mantém-se líder no mercado interno de produtos laminados planos com $52 \%$ de participação, mantendo a liderança nos principais segmentos.

O fluxograma do PDP das unidades de análise, mostrado na figura 22 , indica que qualquer que seja a origem da idéia, o processo inicia na área de marketing que deve ser consultada e deve autorizar o desenvolvimento, após uma prospecção de mercado. Os projetos são definidos, segundo classificação das unidades análise, conforme as seguintes abordagens distintas: desenvolvimento de um novo 
produto $^{23}$; adequação ao uso; melhoria do desempenho de um produto já disponível para vendas; e projeto de melhoria da qualidade.

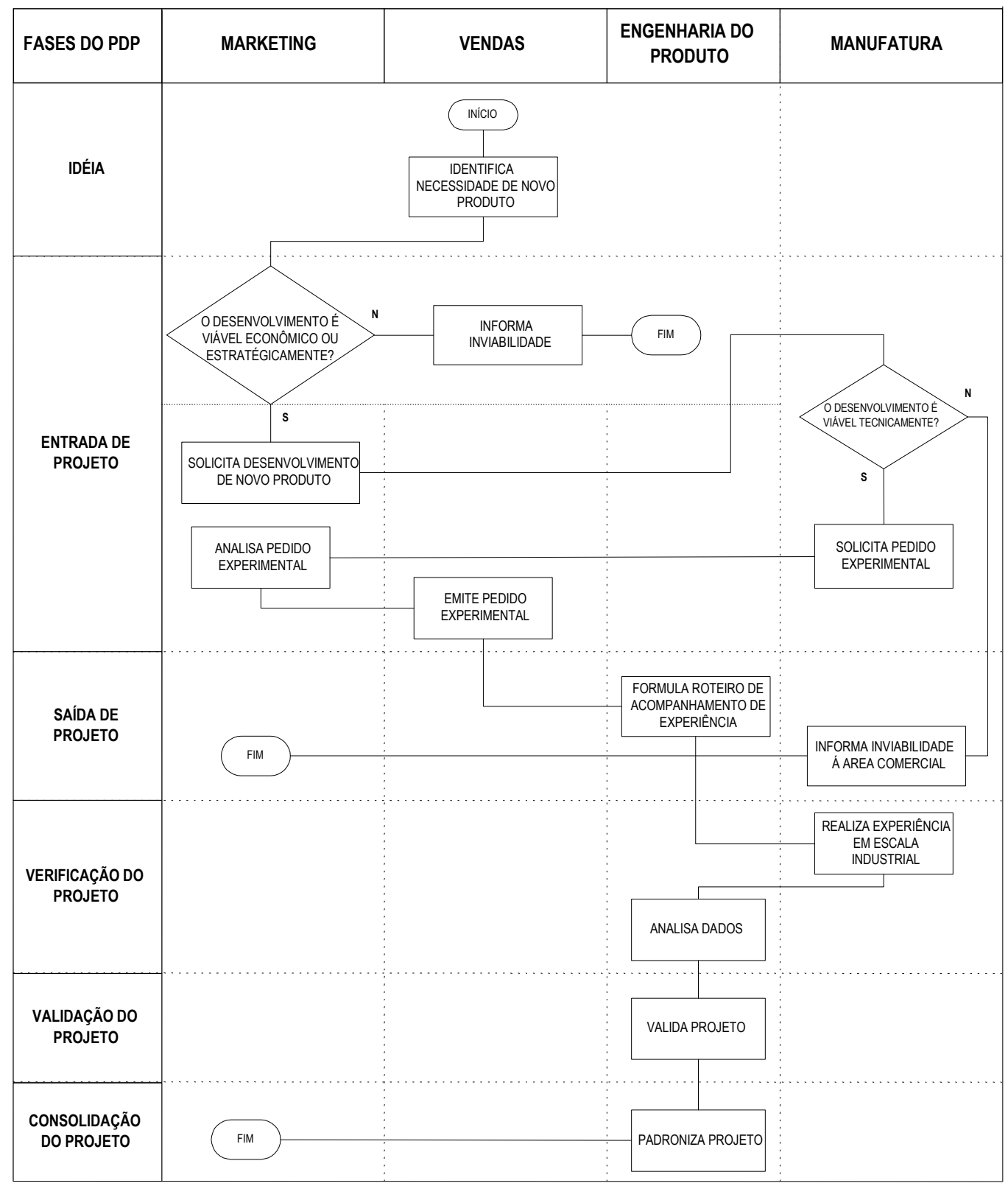

Figura 22 - Fluxograma do PDP nas unidades de análise.

Fonte: Elaborado pelo autor com base nas práticas das unidades de análise.

Para a definição do escopo do projeto, as áreas de marketing e de engenharia do produto definem quais os projetos de novos produtos que serão desenvolvidos. A

${ }^{23} \mathrm{O}$ conceito de novo produto, trata-se de um produto com especificação (grau de qualidade e/ou dimensões), que as unidades de análise não têm em sua carteira de produtos, não existe precificação e não há similaridade com nenhum produto cadastrado. 
seguir, a área de engenharia do produto discute os quesitos tecnológicos com as áreas de manufatura. Se concluir pela inviabilidade do desenvolvimento, informa esta inviabilidade à área de marketing; se o projeto é viável, faz-se reuniões para discussão dos parâmetros técnicos necessários e redige-se um documento denominado Roteiro de Acompanhamento de Experiência (RAE), mostrado no Anexo $B$, no qual se destacam-se: os objetivos do desenvolvimento, as características do pedido, as responsabilidades de cada área, bem como os parâmetros de produção de cada área fabril. Definem-se ainda os testes de liberação e testes complementares, bem como os parâmetros de liberação do material produzido.

O processo de desenvolvimento de novos produtos nas unidades de análise é dividido em cinco fases, conforme descrito a seguir (e ilustrado anteriormente na figura 22):

- Entrada do projeto: o PDP inicia a partir de uma solicitação ou concordância da área de marketing, que deve efetuar e documentar a análise dos riscos presentes no desenvolvimento, incluir o cronograma do desenvolvimento, os recursos disponíveis, os custos do desenvolvimento e os investimentos necessários;

- Saída do projeto: os dados de entrada de um novo projeto são analisados pela engenharia do produto, os projetos são discutidos com as áreas operacionais para elaboração do experimento em escala industrial. Se na discussão do projeto com as áreas operacionais concluir-se pela inviabilidade técnica de sua execução, a área responsável pelo projeto deve informar esta conclusão às áreas solicitantes;

- Verificação do projeto: a verificação do projeto é executada durante a produção dos lotes experimentais. Os dados coletados são analisados pelos responsáveis pelos experimentos e comparados com requisitos de entrada do projeto. São utilizadas técnicas estatísticas e metalúrgicas para a interpretação dos resultados;

- Validação do projeto: a validação do projeto é executada conforme disposições planejadas para assegurar que o produto resultante seja capaz de atender aos requisitos para aplicação especificada ou uso intencional, onde este é conhecido. Esta etapa é considerada como pré-lançamento do produto. A validação pode ocorrer em função dos resultados obtidos 
internamente ou através dos resultados obtidos no cliente. As informações de desempenho do produto são documentadas por relatórios de visita aos clientes, atas de reuniões com os clientes ou documentos dos próprios clientes;

- Consolidação do projeto: após conclusão do desenvolvimento, a partir do acompanhamento dos primeiros lotes fabricados contra pedidos de clientes (fase de pré-venda), a área responsável pelo mesmo emite relatório resumo no qual devem ser informados dados tais como: norma interna de especificação de qualidade, dimensões liberadas para fabricação, rotas de equipamentos necessárias para 0 processamento e, se possível, o rendimento integrado estimado do produto ${ }^{24}$. Este relatório é encaminhado à equipe que solicitou $o$ desenvolvimento, a qual realiza a análise de rentabilidade do novo produto e disponibiliza-o para comercialização.

As revisões de fase são realizadas no final de cada fase ou quando necessário, isto é, quando os parâmetros definidos no RAE não atendem as propriedades exigidas para o produto ou quando os processos de manufatura encontram problemas durante a fabricação do produto.

- Organização de Projeto e de Pessoal Envolvido

A estrutura organizacional do projeto é distribuída da seguinte forma: a área de marketing é a solicitante e coordenadora geral, a área de engenharia do produto é responsável tecnicamente pelo desenvolvimento e a manufatura (Alto forno, Aciaria e Laminação) faz que sejam cumpridos os parâmetros de fabricação definidos no Roteiro de Acompanhamento de Experiência - RAE (Anexo B).

O time é multifuncional, envolvendo uma pessoa de cada área participante do PDP (marketing, engenharia do produto e manufatura) e é definido durante a fase de preparação do RAE. Todo projeto de novo produto tem um gerente de projeto da área de engenharia do produto, que é responsável pelo planejamento e controle do projeto, elabora o RAE e discute o mesmo com as áreas de manufatura, até que haja um consenso dos parâmetros ali definidos. O gerente de projeto também acompanha a condução da experiência industrial, analisa os resultados obtidos, efetua alterações quando necessárias, fornece as informações para as áreas

\footnotetext{
${ }^{24}$ Rendimento integrado de produto consiste na razão entre a somatória da tonelagem produzida de produto (placas, chapas grossas ou tiras) pela tonelagem de material utilizado na sua produção. Neste caso, chama-se rendimento integrado estimado devido a este valor ser obtido no experimento industrial, diferente das condições operacionais em escala de produção normal.
} 
encarregadas da implantação do novo produto nas especificações da empresa e escreve o relatório final de desenvolvimento.

No caso da área de manufatura, existe a figura do gerente funcional, que é responsável por alocação de recursos das áreas e negociação de prazos. Também existe o especialista, que representa as áreas funcionais nas reuniões de projeto e atua na execução de atividades no PDP. Pode-se ter mais de um gerente funcional e especialista por projeto, de acordo com os equipamentos que fazem parte da rota de fabricação do novo produto, que são as pessoas nomeadas responsáveis para 0 cumprimento dos parâmetros operacionais de suas respectivas áreas. $\mathrm{O}$ grau de instrução das pessoas que trabalham nas áreas de manufatura ou engenharia do produto é composto por: técnicos metalúrgicos, engenheiros mecânicos, engenheiros metalúrgicos, engenheiros de materiais ou de produção.

Vale a pena destacar, a função do Centro de P\&D de elaborar projetos de pesquisa de novos produtos quando solicitado e fornecer suporte as áreas envolvidas com o PDP. O Centro de P\&D participa das atividades do PDP, se integrando com as demais áreas das unidades de análise envolvidas com o PDP e tem realizado atividades tecnológicas sistemáticas junto aos clientes, em termos de aprimoramento e desenvolvimento de novas especificações de aço e de aplicações, em muitas situações envolvendo esforços tecnológicos conjuntos do fornecedor e do cliente, bem como otimização de produtos nos processos dos clientes. Trimestralmente, o Centro de P\&D participa de reuniões realizadas com as áreas envolvidas no PDP (marketing, engenharia do produto e manufatura), para atualização e acompanhamento dos projetos estipulados no plano anual, discussão de entradas e retiradas de projetos, levantamento de inputs para a gestão de oportunidades e idéias de novos produtos.

- Liderança e Gerenciamento de Projeto

A área de marketing é responsável pela coordenação geral do PDP, que delega a condução de cada projeto a um líder de equipe (marketing), que junto às outras áreas envolvidas no PDP (engenharia do produto e manufatura), realizam o desenvolvimento de novos produtos.

$\mathrm{Na}$ fase de experimentos industriais, o gerente de engenharia do produto é responsável final pelo andamento, supervisionando os trabalhos do gerente de projeto, que é um engenheiro da área de engenharia do produto. Os gerentes funcionais supervisionam problemas que podem vir a ocorrer em suas áreas de 
atuação, em função do desenvolvimento em andamento. O projeto é gerenciado com base no fluxograma de desenvolvimento de produtos ilustrado anteriormente na figura 22, e por meio de relatórios de acompanhamento do PDP.

- Resolução de Problemas, Testes e Protótipos

Para resolução de problemas são utilizadas técnicas estatísticas e metalúrgicas para a interpretação dos resultados obtidos, além do conhecimento teórico e prático do gerente de projeto. Os testes baseiam-se principalmente na variação dos parâmetros de processo conforme especificações exigidas no produto. A quantidade e tipo de teste oscilam de acordo com a criticidade de cada equipamento participante da rota de fabricação do produto. Alguns exemplos de teste são: oscilação na temperatura do forno de reaquecimento das placas, espessura e planicidade de laminação, propriedades mecânicas, adição de ligas, soldagem, acabamento, etc. Alguns testes podem ser realizados dentro do programa de produção e outros testes podem também ser realizados nos clientes para acompanhamento da performance do produto. No caso dos protótipos, a quantidade de protótipos gerada e a tonelagem utilizada no experimento industrial no PDP são pequenas, devido principalmente aos altos custos envolvidos, às características do processo siderúrgico, e pelo conhecimento técnico dos especialistas dos equipamentos das rotas de fabricação do novo produto.

- Revisões Gerenciais e Controle

As revisões de fase ocorrem sempre ao término de cada fase, sendo obrigatórias para a passagem para a próxima fase e avalia a possibilidade de continuidade do projeto e os riscos envolvidos nesta decisão. Além disso, também são tipicamente utilizadas revisões intermediárias antes do final de cada fase. Com isso se ganha tempo no redirecionamento correto do projeto até a revisão de fase, nas seguintes situações: quando há dificuldades operacionais para a obtenção do produto; quando os resultados obtidos não atendem às especificações normativas; ou quando mesmo atendendo às disposições legais e normativas há dificuldade da aplicação do produto no cliente.

Quando existe a necessidade de uma revisão antes do término da fase, faz-se uma análise crítica na qual são apontados os motivos pelos quais a mesma será realizada, elabora-se um adendo ao RAE, divulgando-o para todas as áreas envolvidas e, se necessário, elabora-se novo cronograma informando a área 
comercial que comunicará o cliente sobre os motivos e novos prazos para realização deste estágio.

As empresas têm estabelecido critérios de quais são as atividades e documentos necessários para passagem de fase, conforme ilustra a figura 23.

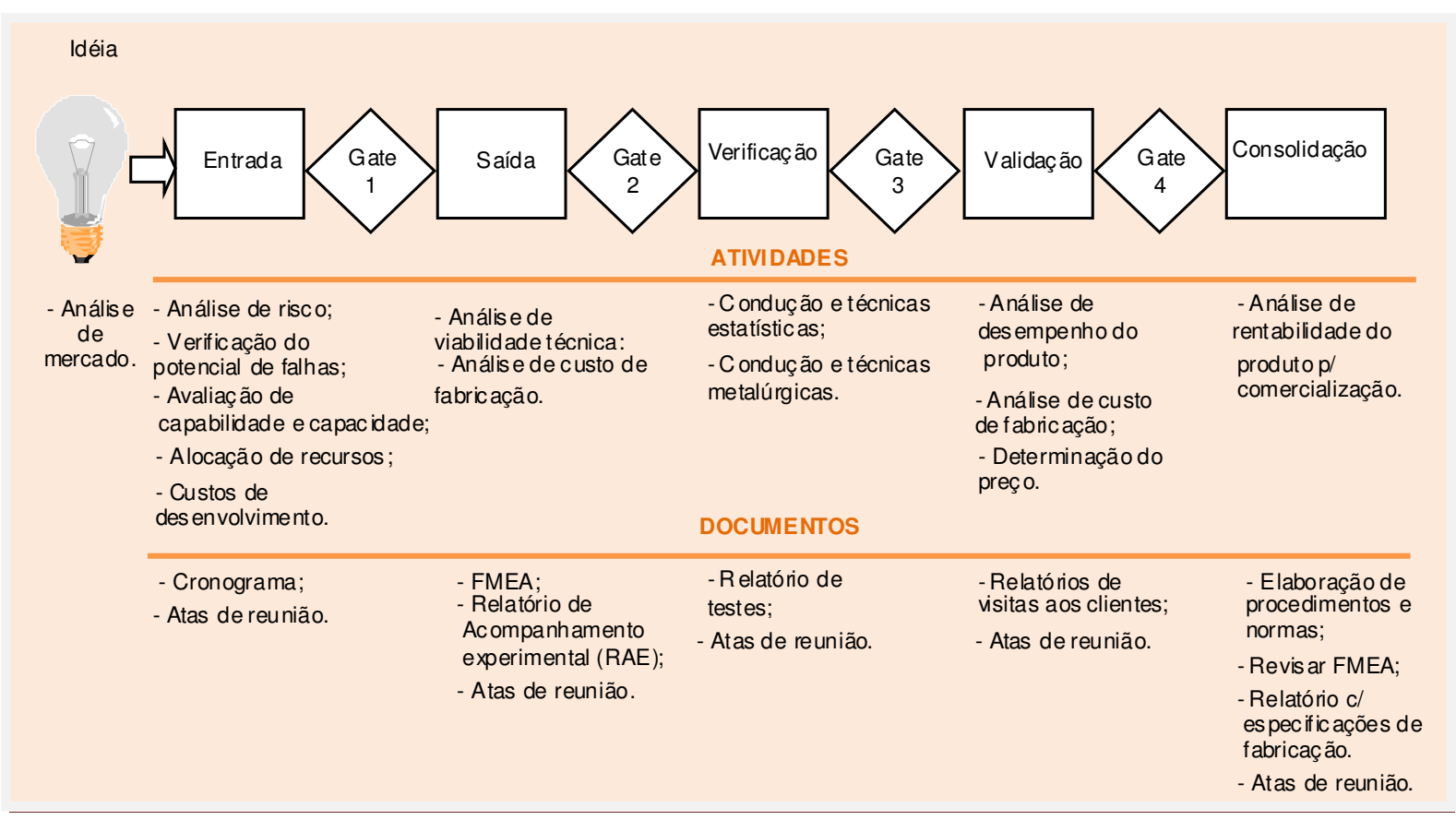

Figura 23 - Os deliverables de passagem de fase no PDP das unidades de análise.

Fonte: Elaborado pelo autor com base nas práticas das unidades de análise.

- Alterações de Projeto

As alterações de projeto são realizadas quando existe a necessidade de correções, ou ainda quando os experimentos não levarem aos resultados almejados de especificação técnica. Quando há necessidade, o gerente de projeto formaliza instruções complementares, por meio de uma revisão ou de adendo do RAE, para conhecimento do pessoal envolvido. Estas alterações são discutidas com as áreas envolvidas e é analisada a viabilidade de implementação. Caso necessário, é elaborado novo cronograma de atividades, e as FMEAs são revistas. Caso aconteça a postergação das atividades que comprometam o prazo final de conclusão do projeto, é feita uma análise crítica nos planos e projetos do cliente bem como na possível perda mercadológica para as unidades de análise, informando o atraso ao cliente. 
Após ter sido utilizada a estrutura referencial propostas por Clark e Wheelwright (1992) para compreender o PDP das unidades de análise, é feita uma análise crítica da estrutura organizacional das unidades de análise. Para isso, são utilizadas três categorias de análise, baseadas no trabalho de Zancul et al. (2006) ${ }^{25}$ : estrutura organizacional; papéis (divisão de tarefas), responsabilidades e autonomia; e mecanismos de integração interfuncional. A tabela 23 ilustra os principais conceitos de cada categoria de análise da estrutura organizacional e mostra como as unidades de análise se comportam.

Tabela 23 - Uma visão da organização do trabalho no PDP das unidades de análise.

\begin{tabular}{|c|c|c|}
\hline $\begin{array}{l}\text { CATEGORIA DE } \\
\text { ANÁLISE }\end{array}$ & LITERATURA & $\begin{array}{l}\text { PDP DAS UNIDADES DE } \\
\text { ANÁLISE } \\
\end{array}$ \\
\hline $\begin{array}{l}\text { Estrutura } \\
\text { organizacional }\end{array}$ & $\begin{array}{l}\text { - Quatro tipos básicos de estrutura } \\
\text { organizacional } \\
\text { para o desenvolvimento de produtos } \\
\text { (CLARK; WHEELWRIGHT, 1993): } \\
\text { - Funcional; } \\
\text { - Autônomo ou por projeto; } \\
\text { - Matricial peso leve; } \\
\text { - Matricial peso pesado. }\end{array}$ & $\begin{array}{l}\text { A estrutura organizacional é } \\
\text { dividida por tipo de projetos de } \\
\text { produtos: } \\
\text { - projetos de tiras a quente; } \\
\text { - projetos de tiras a frio; } \\
\text { - projetos de chapas grossas; } \\
\text { - projetos de placas p/ exportação. } \\
\text { A estrutura de desenvolvimento de } \\
\text { produtos é do tipo matricial peso } \\
\text { leve. }\end{array}$ \\
\hline $\begin{array}{l}\text { Papéis } \\
\text { (divisão de } \\
\text { tarefas), } \\
\text { responsabilidades } \\
\text { e autonomia }\end{array}$ & $\begin{array}{l}\text { Segue alguns papéis e responsabilidades } \\
\text { (ROZENFELD et al., 2006): } \\
\text { - Gerente funcional: responsável por uma } \\
\text { função específica da empresa; } \\
\text { - Gerente de projetos: responsável por um } \\
\text { projeto e líder de um time de } \\
\text { desenvolvimento; } \\
\text { - Especialistas: pessoas de determinadas } \\
\text { áreas funcionais da empresa, que possuem } \\
\text { conhecimento técnico empregado no } \\
\text { processo de fabricação; } \\
\text { - Time de desenvolvimento: responsável por } \\
\text { um projeto específico de desenvolvimento, } \\
\text { esta equipe pode ser formada por pessoas } \\
\text { de diversas áreas. }\end{array}$ & $\begin{array}{l}\text { Três papéis principais no PDP: } \\
\text { - Gerente de projeto; } \\
\text { - Gerente funcional; } \\
\text { - Especialista. } \\
\\
\text { É formado um time de } \\
\text { desenvolvimento multifuncional, } \\
\text { com representantes das áreas de: } \\
\text { Engenharia do produto, Marketing } \\
\text { e Manufatura e se necessário } \\
\text { suporte técnico do Centro de } \\
\text { Pesquisas. }\end{array}$ \\
\hline $\begin{array}{l}\text { Mecanismos de } \\
\text { Integração } \\
\text { interfuncional }\end{array}$ & $\begin{array}{l}\text { - Projeto simultâneo dos produtos e de seus } \\
\text { processos (WINNER et al., 1988). } \\
\text { - Interações no nível de execução do } \\
\text { trabalho, entre as pessoas que atuam } \\
\text { diretamente nas atividades de } \\
\text { desenvolvimento (CLARK; } \\
\text { WHEELWRIGHT, 1993). } \\
\text { - Padrão de comunicação definido pela } \\
\text { riqueza, } \\
\text { freqüência, direção e momento (CLARK; } \\
\text { WHEELRIGHT, 1993). }\end{array}$ & $\begin{array}{l}\text { Existem mecanismos de } \\
\text { integração interfuncional: time de } \\
\text { desenvolvimento, atividades } \\
\text { simultâneas e transferência de } \\
\text { tecnologia. } \\
\text { Porém, existem alguns fatores que } \\
\text { prejudicam a integração: } \\
\text { diferenças de prioridade entre os } \\
\text { envolvidos e distância física entre } \\
\text { as áreas. }\end{array}$ \\
\hline
\end{tabular}
Fonte: Elaborado pelo autor com base na estrutura proposta por Zancul et al. (2006).

${ }^{25}$ A literatura sobre as categorias de análise estão detalhadas pelos autores (ZANCUL et al., 2006). 
As unidades de análise utilizam de uma estrutura matricial "peso leve" em função das características do setor siderúrgico e dos tipos de produtos que são desenvolvidos. A área de marketing é responsável pela coordenação geral do PDP, que delega a condução de cada projeto a um líder de equipe multidisciplinar de marketing, que junto às outras áreas envolvidas no PDP, engenharia do produto e manufatura, realiza o desenvolvimento de novos produtos.

A estrutura organizacional das unidades de análise para o PDP, conforme ilustrado anteriormente na figura 20, não se modifica em termos de coordenação geral do PDP, pois é a área de marketing que controla este processo nas duas plantas. Pode-se alterar apenas na formação da equipe multidisciplinar participante do desenvolvimento, conforme a rota de fabricação do novo produto.

Nos papéis e responsabilidades dos envolvidos no PDP, as unidades de análise têm definido na suas respectivas normas organizacionais os departamentos responsáveis pelas atividades de desenvolvimento de novos produtos e suas atribuições. No quesito integração, as unidades de análise adotam atividades simultâneas e times de desenvolvimento. A integração ocorre principalmente por meio de reuniões, troca de e-mails e relatórios de acompanhamento do PDP. Entretanto, existe alguns fatores que podem prejudicar a integração, devido principalmente a cada área funcional possuir diferentes prioridades e também a distância física entre as áreas envolvidas no PDP ser muito grande.

Resumindo, a adoção de estrutura matricial "peso leve" e utilização de time multidisciplinar no PDP pelas unidades de análise implica em algumas vantagens diferenciais tais como: melhoria no canal de comunicação, maior difusão das informações, melhoria da cooperação e dos relacionamentos interfuncionais. Tais características contribuem para a redução do tempo de desenvolvimento, como também para ajustes no processo em virtude dos efeitos do mercado, das ações de concorrência e de restrições dos equipamentos.

A estrutura organizacional das unidades de análise conta com suporte técnico do Centro de P\&D, e também há uma prática de transferência de tecnologia entre as plantas para desenvolvimento de novos produtos. O processo de desenvolvimento de novo produto específico de uma unidade de análise para outra, passa praticamente pelas mesmas fases do PDP descrito anteriormente no fluxograma da figura 22, porém sofre ajustes pela equipe de desenvolvimento de novos produtos às 
características de cada equipamento da rota de produção de cada planta, que são diferentes uma da outra.

Além disso, as unidades de análise possuem práticas de aprendizagem organizacional e de melhoria contínua, ou seja, por meio de treinamento dos funcionários em novas práticas operacionais e pelo registro, no sistema eletrônico ISO SYSTEM ${ }^{26}$, de todas as ocorrências de não conformidades detectadas em auditorias internas e externas. Neste sistema são documentadas as propostas de melhorias e como são tratadas as não conformidades detectadas, e as respectivas pessoas responsáveis pela análise de causas e planos de ação, que são detalhadas em atividades de planejamento, execução e verificação.

A fim de encerrar esta seção sobre a descrição da estrutura do PDP, vale à pena enfatizar que as unidades analisadas utilizam métodos e técnicas de suporte ao PDP, sendo que a área de marketing realiza a análise de mercado, a análise de risco potencial de falhas e a análise de custos de fabricação. A área de engenharia de produto informa à área de custos uma referência de produto similar cadastrada, para que se estime o custo de fabricação do novo produto. Se não houver nenhuma qualidade similar, a engenharia do produto deve envolver os especialistas da área de manufatura, que fazem previsões de rendimentos em cada um dos equipamentos envolvidos na rota de fabricação, para subsidiar as informações necessárias para a área de custos estimar o custo de fabricação do novo produto, e enviar à área de marketing.

Nos casos das FMEAs relativas ao desenvolvimento de produto, que impacte nas FMEAs de processo, a área de engenharia do produto elabora e revisa estes documentos, sendo também responsável pela elaboração do RAE; utilização de técnicas estatísticas e metalúrgicas; e análise de viabilidade técnica do desenvolvimento de novos produtos.

Após análise da estrutura do PDP das unidades de análise, a seguir é realizada uma descrição das principais atividades da fase de projeto do processo no PDP, tentando entender como funciona esta fase e como as principais variáveis selecionadas na literatura se relacionam ao projeto do processo.

\footnotetext{
${ }^{26}$ Este software proporciona o controle de documentos referentes às normas ISO 9001 (2000), facilitando no gerenciamento de não conformidades, planos de melhorias, ações de correção, rastreabilidade de documentos e melhor planejamento de treinamento dos funcionários.
} 


\subsection{Análise da fase de projeto do processo no PDP das unidades de análise}

Esta seção busca através das principais variáveis identificadas no referencial teórico, compreender como as unidades de análise conduzem a fase de projeto do processo $^{27}$ e verificar o entendimento das áreas envolvidas neste processo sobre a importância das principais variáveis para cada fase do PDP.

Visto que a estrutura organizacional das unidades de análise não se modifica em termos de coordenação geral do PDP, pois é a área de marketing que coordena este processo nas duas unidades de análise. Nesta seção é tratada a fase de projeto do processo, que apresenta uma diferença identificada e destacada a seguir na formação da estrutura organizacional. Essa diferença envolve a condução do desenvolvimento industrial no PDP nas unidades de análise.

Uma diferença identificada na estrutura organizacional das unidades de análise está na área de engenharia do produto, em que cada unidade de análise tem uma superintendência responsável pelo desenvolvimento industrial do PDP. Na Planta-1 é denominada de Superintendência de Qualidade e Assistência Técnica, que tem três gerências subordinadas (Assistência Técnica, Controle Integrado de Produto, e Garantia da Qualidade), e na Planta-2 é denominada de Superintendência de Metalurgia e Garantia da Qualidade, que também possui três gerências subordinadas (Controle Integrado de Laminados a Frio e Revestidos, Controle Integrado de Laminados a Quente, e Laboratório e Ensaios de Liberação), sendo que as superintendências têm responsabilidades iguais, tanto na condução do PDP, quanto na estrutura funcional das respectivas unidades.

No entanto, na Planta-1 esta função de conduzir a fase de projeto do processo é centralizada em uma gerência (Assistência Técnica) e na Planta-2, existem duas gerências (Controle Integrado de Laminados a Frio e Revestidos, e Controle Integrado de Laminados a Quente) para realizar esta mesma atividade de desenvolvimento de novos produtos. Isto se deve em parte ao fato da Planta-2 ter uma linha de galvanização, equipamento que a Planta-1 não tem, e duas linhas de laminação a frio, sendo que a Planta-1 possui apenas uma linha.

${ }^{27}$ A fase de projeto do processo neste trabalho considera a fase de engenharia do produto/processo e parte da produção piloto/aumento de produção (CLARK; WHEELWRIGHT, 1992). 
Analisando a diferença na estrutura funcional de cada unidade de análise, verifica-se que a estrutura da Planta-2 é considerada melhor organizada devido as atribuições de condução de experimentos de melhoria de desempenho de produto estarem juntas com a de desenvolvimento de novos produtos. Destaca-se o fato de também ter uma gerência para cada rota de fabricação de produto, assim envolve mais pessoas na condução do PDP. Além disso, a estrutura da Planta-2 está preparada para uma demanda maior de projetos a serem desenvolvidos que os praticados na Planta-1, devido principalmente a disponibilidade de recursos (duas linhas de laminação a frio e uma linha de galvanização) que facilita no planejamento e execução do experimento e, conseqüentemente, a Planta-2 possui três vezes mais mão-de-obra envolvida na condução do PDP.

As unidades de análise têm a fase de projeto de processo estruturada de forma matricial para atender aos diferentes tipos de projetos de produtos, ou seja, as áreas de engenharia do produto e manufatura se alteram na composição das equipes multidisciplinares envolvidas de acordo com a rota de fabricação do novo produto.

Nas duas unidades de análise, a área de engenharia do produto, coordenadora da fase de projeto do processo no PDP, é dividida por tipo de projetos de produtos a ser desenvolvido (chapas grossas, tiras laminadas a quente, tiras laminadas a frio, revestidos e placas para exportação). Percebe-se que a estrutura organizacional se assemelha a de time "peso leve", no qual o engenheiro da área de engenharia de produto (gerente peso leve) é responsável pelo andamento dos experimentos industriais. Entretanto, o gerente não tem autonomia sobre os processos de desenvolvimento realizados na manufatura. Existe a figura dos gerentes de manufatura (gerentes funcionais), que são responsáveis diretos pelo desenvolvimento de novos produtos em suas respectivas áreas de atuação. Quando não se consegue conduzir o projeto conforme planejado, devido a divergências entre os envolvidos no time multifuncional, a discussão deve subir para o nível gerencial para o nível de superintendência e, posteriormente, para o nível de diretoria, destacando que ainda não houve a necessidade de ocorrência deste fato chegar ao nível gerencial.

Após entendimento da estrutura organizacional da fase de projeto do processo, entre as unidades de análise, são tratadas a seguir as variáveis técnicas que se relacionam a esta fase do PDP, e sua respectiva importância para o sucesso no 
desenvolvimento de novos produtos no contexto de (aços planos do setor siderúrgico brasileiro).

No referencial teórico foram identificados, na varredura vertical, as principais variáveis relacionadas ao projeto do processo no PDP pesquisados por diversos autores. Para definir o contorno dos tópicos a serem analisados neste trabalho, foi elaborada uma tabela para avaliação do grau de importância de cada variável do PDP, objetivando realizar uma análise mais apurada das principais variáveis selecionados, reduzindo assim a quantidade de variáveis a serem tratadas no presente trabalho.

Essa tabela consiste de 32 variáveis selecionadas na literatura como mais importantes e foi aplicada às áreas envolvidas no PDP (o resultado é mostrado a seguir na tabela 24 e os detalhes da pontuação completa estão no Apêndice C). A escala da tabela foi adaptada da escala geralmente usada no método de QFD, ou seja, foi utilizado o seguinte critério de relação: 0 - nenhuma relação; 1 - baixa relação; 3 - média relação; e 9 - alta relação. Então, esta tabela foi pontuada por profissionais das áreas de marketing, engenharia de produto e manufatura, que avaliaram cada uma das 32 variáveis atribuindo a importância para cada fase do PDP das unidades de análise (desenvolvimento do conceito, planejamento do produto, engenharia do produto/processo, e produção piloto/aumento da produção). Depois foi feita uma somatória das notas em cada fase, para cada variável, e selecionadas as variáveis mais importantes no PDP com base na maior pontuação.

A seguir, a tabela 24 traz todas variáveis pontuadas e destaca-se em negrito e sombreado as 12 variáveis que obtiveram nota igual ou superior a 80 pontos. Essa foi a nota de corte com objetivo de reduzir a quantidade de variáveis a serem analisadas. A utilização da nota de corte baseia-se em analisar as variáveis acima da pontuação média do conjunto de dados avaliados.

Tabela 24 - As principais variáveis relacionadas ao PDP na visão das áreas envolvidas no desenvolvimento de novos produtos.

\begin{tabular}{l|c|c|c|c}
\hline \multicolumn{1}{c|}{ PRINCIPAIS VARIÁVEIS } & MARKETING & $\begin{array}{c}\text { ENG. DO } \\
\text { PRODUTO }\end{array}$ & MANUFATURA & TOTAL \\
\hline Trabalho de equipe & 36 & 36 & 36 & 108 \\
\hline Colaboração e comunicação & 36 & 30 & 36 & 102 \\
\hline Aprendizagem do time & 36 & 24 & 36 & 96 \\
\hline
\end{tabular}

Fonte: Elaborado pelo autor com base em dados primários. 
Tabela 24 - As principais variáveis relacionadas ao PDP na visão das áreas envolvidas no desenvolvimento de novos produtos - Continuação.

\begin{tabular}{|c|c|c|c|c|}
\hline PRINCIPAIS VARIÁVEIS & MARKETING & $\begin{array}{l}\text { ENG. DO } \\
\text { PRODUTO }\end{array}$ & MANUFATURA & TOTAL \\
\hline $\begin{array}{l}\text { Entender os problemas das áreas } \\
\text { envolvidas }\end{array}$ & 36 & 30 & 30 & 96 \\
\hline Necessidade de padrões claros & 36 & 24 & 36 & 96 \\
\hline Produtividade do time & 36 & 30 & 28 & 94 \\
\hline Fatores de sucesso & 36 & 16 & 36 & 88 \\
\hline Melhoria contínua e performance & 36 & 22 & 30 & 88 \\
\hline Sistema de informação & 36 & 30 & 22 & 88 \\
\hline $\begin{array}{l}\text { Duração do ciclo de desenvolvimento } \\
\text { de produtos }\end{array}$ & 36 & 24 & 20 & 80 \\
\hline Envolvimento da alta gerência & 36 & 30 & 14 & 80 \\
\hline Gestão & 36 & 16 & 28 & 80 \\
\hline Interação das variáveis de processo & 36 & 21 & 22 & 79 \\
\hline Tomada de decisão no PDP & 36 & 21 & 22 & 79 \\
\hline $\begin{array}{l}\text { Utilização de ferramentas estatísticas no } \\
\text { PDP }\end{array}$ & 36 & 19 & 22 & 77 \\
\hline Planejamento de processo no PDP & 36 & 22 & 18 & 76 \\
\hline Stage-Gate e revisão de fases & 36 & 24 & 16 & 76 \\
\hline Integração do PDP & 36 & 3 & 36 & 75 \\
\hline Times multifuncionais no PDP & 30 & 22 & 22 & 74 \\
\hline Cumprimento de prazos no PDP & 30 & 18 & 24 & 72 \\
\hline Definição de responsabilidades no PDP & 18 & 30 & 22 & 70 \\
\hline Estratégia no PDP & 36 & 12 & 22 & 70 \\
\hline $\begin{array}{l}\text { Evitar perda de conhecimento } \\
\text { (experiência adquirida no PDP) }\end{array}$ & 36 & 14 & 20 & 70 \\
\hline Product development business process & 36 & 12 & 22 & 70 \\
\hline Gerenciamento de projetos & 36 & 10 & 22 & 68 \\
\hline Inovação tecnológica para PDP & 30 & 18 & 20 & 68 \\
\hline $\begin{array}{l}\text { Mecanismo de controle da alta gerência } \\
\text { para o PDP }\end{array}$ & 36 & 10 & 22 & 68 \\
\hline $\begin{array}{l}\text { Processos de projetos e produtos } \\
\text { complexos }\end{array}$ & 36 & 4 & 28 & 68 \\
\hline Diretriz para gerentes de projeto & 36 & 10 & 16 & 62 \\
\hline Indicadores de desempenho & 30 & 8 & 22 & 60 \\
\hline Ambiente de incerteza no PDP & 12 & 8 & 20 & 40 \\
\hline $\begin{array}{l}\text { Mudanças organizacionais no } \\
\text { desenvolvimento de produtos }\end{array}$ & 12 & 9 & 14 & 35 \\
\hline
\end{tabular}

Fonte: Elaborado pelo autor com base em dados primários.

Apesar de entre as duas unidades de análise não ter havido diferenças na percepção da importância das variáveis relacionadas ao PDP, é importante destacar algumas discrepâncias de percepção entre as áreas envolvidas no PDP. A área de engenharia de produto para algumas variáveis (integração do PDP, gerenciamento de projetos, mecanismos de controle da alta gerência para o PDP, processos de projetos e produtos complexos, e indicadores de desempenho) pontuou como baixa 
relação ao PDP. No entanto, as áreas de marketing e manufatura consideraram importantes estas variáveis para o PDP.

Associado a esta análise comparativa, salienta-se que para a área de marketing as duas fases finais do PDP (Engenharia do produto/processo e Produção piloto/aumento da produção) obtiveram maior importância para o PDP, enquanto que para as áreas de engenharia do produto e manufatura foram ás fases intermediárias do PDP (Planejamento do produto e Engenharia do produto/processo).

Esta discordância conceitual das diferentes áreas envolvidas no PDP, sobre o entendimento da importância de algumas variáveis, vai de encontro ao apontado no referencial teórico deste trabalho, que destaca as dificuldades na condução do PDP, devido a falta de integração e aos diferentes objetivos entre as áreas envolvidas no PDP.

No entanto, como uma das ênfases do presente trabalho está na fase de projeto do processo, optou-se por analisar somente as variáveis avaliadas como mais importantes para esta fase, e não a somatória de cada fase, que representa a importância das variáveis para o processo de desenvolvimento de novos produtos, conforme indicado na tabela 24.

Assim sendo, foram selecionadas as variáveis que receberam maior pontuação nas fases de engenharia do produto/processo, e produção piloto/aumento da produção, descartando os pontos obtidos nas fases de desenvolvimento do conceito e planejamento do produto. A tabela 25 demonstra todas variáveis pontuadas e destaca-se em negrito e sombreado as 10 variáveis melhor avaliadas no projeto do processo, com uma nota de corte de 46 pontos que representa pouco mais de $85 \%$ dos 54 pontos totais possíveis ${ }^{28}$. Para nota de corte, foram seguidos os mesmos critérios da nota de corte anteriormente descritos para as variáveis do PDP.

\footnotetext{
${ }^{28} \mathrm{Na}$ análise foram consideras duas fases (engenharia do produto/processo e produção piloto/aumento da produção), que foram avaliadas pelas três áreas (marketing, engenharia do produto e manufatura), portanto a nota máxima possível é 54, ou seja: 2 fases $\times 3$ notas uma de cada área, sendo a maior nota 9 - alta relação $(2 \times 3 \times 9=54)$.
} 
Tabela 25 - As principais variáveis relacionadas ao projeto do processo na visão das áreas envolvidas no PDP.

\begin{tabular}{|c|c|c|c|c|}
\hline PRINCIPAIS VARIÁVEIS & MARKETING & $\begin{array}{l}\text { ENG. DO } \\
\text { PRODUTO }\end{array}$ & MANUFATURA & TOTAL \\
\hline Colaboração e comunicação no PDP & 18 & 18 & 18 & 54 \\
\hline Trabalho de equipe no PDP & 18 & 18 & 18 & 54 \\
\hline Aprendizagem do time no PDP & 18 & 12 & 18 & 48 \\
\hline $\begin{array}{l}\text { Entender os problemas das áreas } \\
\text { envolvidas no PDP }\end{array}$ & 18 & 18 & 12 & 48 \\
\hline Inovação tecnológica para PDP & 18 & 12 & 18 & 48 \\
\hline Interação das variáveis de processo & 18 & 18 & 12 & 48 \\
\hline $\begin{array}{l}\text { Necessidade de padrões claros no } \\
\text { PDP }\end{array}$ & 18 & 12 & 18 & 48 \\
\hline Produtividade do time no PDP & 18 & 12 & 18 & 48 \\
\hline $\begin{array}{l}\text { Melhoria contínua e performance no } \\
\text { PDP }\end{array}$ & 18 & 10 & 18 & 46 \\
\hline Sistema de informação no PDP & 18 & 18 & 10 & 46 \\
\hline $\begin{array}{l}\text { Utilização de ferramentas estatísticas no } \\
\text { PDP }\end{array}$ & 18 & 18 & 10 & 46 \\
\hline $\begin{array}{l}\text { Duração do ciclo de desenvolvimento de } \\
\text { produtos }\end{array}$ & 18 & 12 & 10 & 40 \\
\hline Fatores de sucesso no PDP & 18 & 4 & 18 & 40 \\
\hline Stage-Gate e revisão de fases & 18 & 12 & 10 & 40 \\
\hline Times multifuncionais no PDP & 18 & 12 & 10 & 40 \\
\hline Tomada de decisão no PDP & 18 & 12 & 10 & 40 \\
\hline Evitar perda de conhecimento & 18 & 10 & 10 & 38 \\
\hline Gestão do PDP & 18 & 10 & 10 & 38 \\
\hline Integração do PDP & 18 & 2 & 18 & 38 \\
\hline $\begin{array}{l}\text { Processos de projeto e produto } \\
\text { complexos }\end{array}$ & 18 & 2 & 18 & 38 \\
\hline Cumprimento de prazos no PDP & 18 & 6 & 12 & 36 \\
\hline Definição de responsabilidades no PDP & 6 & 18 & 12 & 36 \\
\hline Gerenciamento de projetos & 18 & 4 & 12 & 34 \\
\hline Indicadores de desempenho & 18 & 4 & 12 & 34 \\
\hline Planejamento de processo no PDP & 18 & 10 & 6 & 34 \\
\hline Envolvimento da alta gerência no PDP & 18 & 12 & 2 & 32 \\
\hline Estratégia no PDP & 18 & 2 & 12 & 32 \\
\hline Product development business process & 18 & 0 & 10 & 28 \\
\hline Diretriz para gerentes de projeto & 18 & 4 & 4 & 26 \\
\hline $\begin{array}{l}\text { Mecanismo de controle da alta gerência } \\
\text { para o PDP }\end{array}$ & 18 & 4 & 4 & 26 \\
\hline $\begin{array}{l}\text { Mudanças organizacionais no } \\
\text { desenvolvimento de produtos }\end{array}$ & 6 & 3 & 10 & 19 \\
\hline Ambiente de incerteza no PDP & 6 & 2 & 2 & 10 \\
\hline
\end{tabular}

Fonte: Elaborado pelo autor.

As variáveis citadas na tabela 25 serviram de base para elaboração de um questionário (Apêndice $\mathrm{E}$ ), com o objetivo de investigar com mais detalhes a importância destas variáveis com a fase de projeto do processo no PDP das unidades. 
Esse questionário foi elaborado com perguntas abertas sobre as 10 principais variáveis à fase de projeto do processo, o que ajudou na obtenção de dados mais elaborados pelos respondentes. As perguntas do questionário (que podem ser visto por completo no Apêndice E) abordam os assuntos: integração interfuncional do time de desenvolvimento; comunicação entre as equipes; como se controla a produtividade e performance do time de desenvolvimento; se existem práticas de melhoria contínua e aprendizagem; qual a influência da inovação tecnológica no processo; auxílio do sistema de informação no processamento de dados; e se existe procedimentos claros de condução do PDP. Fazendo uma análise dos dados obtidos com a aplicação do questionário do Apêndice $E$, segue na tabela 26 uma análise das principais variáveis com a fase de projeto do processo nas unidades de análise.

Tabela 26 - Análise das principais variáveis selecionadas na literatura com o projeto do processo das unidades de análise.

\begin{tabular}{|c|c|c|}
\hline $\begin{array}{l}\text { PRINCIPAIS } \\
\text { VARIÁVEIS }\end{array}$ & LITERATURA & PROJETO DO PROCESSO \\
\hline $\begin{array}{l}\text { Trabalho de } \\
\text { equipe }\end{array}$ & $\begin{array}{l}\text { Ao longo do Projeto do Processo é importante que } \\
\text { se busque o trabalho em equipe, de forma que as } \\
\text { partes envolvidas percebam que suas } \\
\text { contribuições individuais se encaixam em um todo } \\
\text { maior, dado pelo esforço conjunto da equipe. }\end{array}$ & $\begin{array}{l}\text { É formado um time multifuncional } \\
\text { de desenvolvimento, coordenado } \\
\text { pela Engenharia do Produto, } \\
\text { buscando sempre o trabalho em } \\
\text { equipe. }\end{array}$ \\
\hline $\begin{array}{l}\text { Colaboração e } \\
\text { comunicação }\end{array}$ & $\begin{array}{l}\text { A comunicação refere-se à troca de informações, } \\
\text { valendo para os tipos verbais e escritos. A } \\
\text { colaboração diferencia-se da comunicação devido } \\
\text { ao foco em aspectos como trabalho em grupo, } \\
\text { compartilhamento de recursos, confiança mútua, e } \\
\text { objetivo e visão comuns, ou seja, aspectos mais } \\
\text { informais e subjetivos. }\end{array}$ & $\begin{array}{l}\text { A comunicação ocorre por meio de } \\
\text { reuniões periódicas; troca de } e^{-} \\
\text {mails; e relatório de } \\
\text { acompanhamento do projeto. }\end{array}$ \\
\hline $\begin{array}{l}\text { Aprendizagem } \\
\text { do time }\end{array}$ & $\begin{array}{l}\text { A aprendizagem se dá principalmente pela troca } \\
\text { de informações obtidas por meio da experiência no } \\
\text { Projeto do Processo, e o mais importante é não se } \\
\text { esquecer de documentá-las. }\end{array}$ & $\begin{array}{l}\text { Toda documentação é arquivada, e } \\
\text { são divulgados os resultados via } \\
\text { relatório. Quando surge uma } \\
\text { atualização das atividades, esta é } \\
\text { normalizada e em seguida o } \\
\text { pessoal envolvido é treinado. }\end{array}$ \\
\hline $\begin{array}{l}\text { Entender os } \\
\text { problemas das } \\
\text { áreas } \\
\text { envolvidas }\end{array}$ & $\begin{array}{l}\text { Através da integração busca-se entender as } \\
\text { limitações e variáveis de processo envolvidas no } \\
\text { Projeto do Processo. }\end{array}$ & $\begin{array}{l}\text { Nas reuniões os especialistas das } \\
\text { áreas expõem as restrições de } \\
\text { processo de seus equipamentos. }\end{array}$ \\
\hline
\end{tabular}

Fonte: Elaborado pelo autor. 
Tabela 26 - Análise das principais variáveis selecionadas na literatura com o projeto do processo das unidades de análise - Continuação.

\begin{tabular}{|c|c|c|}
\hline $\begin{array}{l}\text { PRINCIPAIS } \\
\text { VARIÁVEIS }\end{array}$ & LITERATURA & PROJETO DO PROCESSO \\
\hline $\begin{array}{l}\text { Inovação } \\
\text { tecnológica }\end{array}$ & $\begin{array}{l}\text { A inovação tecnológica consiste em sua essência, } \\
\text { na busca, descoberta, experimentação, } \\
\text { desenvolvimento e adoção de novos produtos ou } \\
\text { novos processos produtivos. }\end{array}$ & $\begin{array}{l}\text { Um fator limitante na fase de Projeto } \\
\text { de Processo é o estado tecnológico } \\
\text { dos equipamentos, que limitam a } \\
\text { fabricação de determinados } \\
\text { produtos. }\end{array}$ \\
\hline $\begin{array}{l}\text { Interação das } \\
\text { variáveis de } \\
\text { processo }\end{array}$ & $\begin{array}{l}\text { Consiste em ter uma visão comum de todas as } \\
\text { atividades do processo e suas variáveis, e } \\
\text { compartilhar informações e recursos para obter } \\
\text { melhores resultados. }\end{array}$ & $\begin{array}{l}\text { No Projeto do Processo existem } \\
\text { muitos equipamentos totalmente } \\
\text { diferentes, que necessitam de } \\
\text { conhecimentos específicos, daí a } \\
\text { necessidade dos especialistas } \\
\text { participarem das reuniões e expor } \\
\text { seu conhecimento. }\end{array}$ \\
\hline $\begin{array}{l}\text { Necessidade } \\
\text { de padrões } \\
\text { claros }\end{array}$ & $\begin{array}{l}\text { A padronização é o estabelecimento de regras } \\
\text { comuns e procedimentos que se aplicam } \\
\text { uniformemente a todos, em quase todas as } \\
\text { situações. }\end{array}$ & $\begin{array}{l}\text { Nas unidades existem normas de } \\
\text { qualidade e documentos } \\
\text { complementares, que detalham } \\
\text { todos os procedimentos do Projeto } \\
\text { do Processo. }\end{array}$ \\
\hline $\begin{array}{l}\text { Produtividade } \\
\text { do time }\end{array}$ & $\begin{array}{l}\text { A produtividade do time está diretamente } \\
\text { relacionada às condições fornecidas pelos } \\
\text { gerentes de projeto e aos resultados conseguidos } \\
\text { com o Projeto do Processo. }\end{array}$ & $\begin{array}{l}\text { O acompanhamento é do produto, } \\
\text { mas exige-se do time de } \\
\text { desenvolvimento: resultados } \\
\text { técnicos; custo do produto; e o } \\
\text { cumprimento dos prazos } \\
\text { planejados. }\end{array}$ \\
\hline $\begin{array}{l}\text { Melhoria } \\
\text { contínua e } \\
\text { performance }\end{array}$ & $\begin{array}{l}\text { Toda mudança é uma oportunidade de melhoria e } \\
\text { aprendizado, a metodologia de gerenciamento de } \\
\text { melhoria mais utilizada é baseada no ciclo } \\
\text { planejar, executar, verificar e agir corretivamente } \\
\text { (ciclo PDCA). }\end{array}$ & $\begin{array}{l}\text { As unidades utilizam o PDCA, e } \\
\text { monitoram a performance do } \\
\text { produto fazendo ajustes. Também } \\
\text { tem o software ISO SYSTEM. }\end{array}$ \\
\hline $\begin{array}{l}\text { Sistema de } \\
\text { informação }\end{array}$ & $\begin{array}{l}\text { É utilizada como ferramenta de apoio, facilitando a } \\
\text { manipulação dos dados para o emprego de } \\
\text { técnicas e métodos disponíveis na área, sua } \\
\text { principal vantagem é a velocidade de } \\
\text { processamento e análise de dados, facilitando a } \\
\text { geração de relatórios. }\end{array}$ & $\begin{array}{l}\text { Existe um banco de dados no } \\
\text { "Sistema de automação de } \\
\text { produção" e ferramentas } \\
\text { estatísticas. }\end{array}$ \\
\hline
\end{tabular}

Fonte: Elaborado pelo autor.

Realizando uma análise das principais variáveis da tabela $26 \mathrm{com}$ a fase de projeto do processo nas unidades de análise, percebe-se que o "trabalho em equipe" é relevante para se conduzir esta fase do PDP, devido principalmente à natureza do processo siderúrgico de possuir equipamentos complexos (Alto Forno, Aciaria, Laminação, etc.) que necessitam de conhecimentos específicos (especialistas) para cada rota de fabricação do produto. Devido a esta complexidade organizacional, a área de engenharia de produto se estrutura por tipo de projetos de produtos a ser desenvolvido, e os gerentes de projetos são engenheiros qualificados com no mínimo cinco anos de experiência em processo siderúrgico. Logo, a utilização de 
uma equipe multifuncional nesta etapa do desenvolvimento de novos produtos facilita o trabalho dos gerentes de projetos, em termos de compartilhamento de conhecimentos junto aos especialistas de manufatura.

No tópico "colaboração e comunicação", identifica-se uma facilidade na troca de informações na organização, que gera agilidade no entendimento e solução de interferências operacionais, durante o experimento industrial. Esta facilidade está relacionada a utilização de algumas práticas, tais como: realizar reuniões periódicas, acompanhar na área o desenvolvimento do experimento e checar os projetos via relatórios.

Nos quesitos "aprendizagem do time" no PDP e "necessidade de padrões claros", as unidades são beneficiadas pela característica do setor siderúrgico de possuir todos os procedimentos normalizados. A constante manutenção das certificações de qualidade, que documentam de forma clara todas as atividades relacionadas ao projeto do processo e que exigem o treinamento das pessoas envolvidas a cada modificação nos procedimentos.

A "produtividade do time" no projeto do processo está diretamente relacionada em cumprir às condições estabelecidas na reunião de abertura do desenvolvimento de novo produto (prazo planejado, custo do produto, e resultados técnicos). A área de engenharia de produto é a responsável pela condução da fase de projeto do processo, e emite relatório bimestral com o status dos projetos à área de marketing que coordena de maneira geral o PDP.

As práticas de "melhoria contínua" na fase de projeto do processo acontecem de duas maneiras em ambas as unidades analisadas, uma quando ocorrem dificuldades durante esta fase, que podem causar atrasos ou impedimentos ao andamento do processo, logo se evita e minimiza os seus efeitos ao longo do desenvolvimento industrial. A outra melhoria acontece quando o novo produto é implantado e ao se monitorar o seu desempenho e constatar baixo rendimento, são feitos ajustes de conformidade e rendimento para posterior liberação como especificação automática. Somando-se a estas práticas de melhoria, existe um software direcionado as organizações credenciadoras da norma ISSO 9001, ISO SYSTEM, no qual são documentadas as propostas de melhorias, como são tratadas as não conformidades detectadas nas auditorias e o planejamento do treinamento do pessoal envolvido. 
O "sistema de informação" tem como principal vantagem na fase de projeto do processo, de acelerar a capacidade de processar um enorme número de dados simultaneamente, tornando a disponibilização das informações demandadas, praticamente on-line para os envolvidos no processo e facilitando a gestão, ainda mais em empresas do setor siderúrgico que lidam com muitas variáveis de processo.

Apesar de o setor siderúrgico possuir sistemas de informação, integrando as áreas de produção, na fase de projeto do processo é de suma importância que a equipe multidisciplinar do PDP tenha uma visão comum de todas as atividades do projeto do processo e suas respectivas variáveis, e compartilhe informações e recursos para se obter melhores resultados. Por isso, a importância da participação dos especialistas dos equipamentos, responsável pelas rotas de fabricação do novo produto, nas reuniões para expor as limitações de processo e acompanhar 0 desenvolvimento do produto nas suas respectivas áreas.

Um tópico considerado crítico na fase de projeto do processo no setor siderúrgico é o "grau de inovação tecnológica", que consiste na capacidade da empresa em desenvolver novos produtos ou novos processos, decorrentes da incorporação de novas tecnologias. O estado tecnológico dos equipamentos pode limitar a fabricação de determinados produtos, devido às exigências, cada vez maiores, das especificações dos clientes. No entanto, percebe-se que há um acúmulo de competências tecnológicas inovadoras, quanto à capacidade de introduzir mudanças técnicas incrementais em processos de fabricação, desenvolvimento de produtos e melhoria do desempenho dos equipamentos (PAULA, 2005). Além disso, vale a pena destacar que existe uma preocupação do setor com inovação tecnológica, uma prova disso é a quantidade de patentes depositadas no Brasil, conforme dados da pesquisa ANPEI.

Finalizando esta seção, é importante destacar que devido alta gerência ter atribuições de tomar decisões e solucionar problemas de interface organizacional no PDP, ainda não houve necessidade de se interferir no andamento da fase de projeto do processo, pois o próprio gerente de projeto "peso leve" resolve junto ao time de desenvolvimento. Como conseqüência, há indícios que as unidades por terem o projeto do processo estruturado de forma matricial, com auxílio de sistemas informatizados, trabalho em equipe, e baseado em normas de qualidade, propicia a alta gerência a tomada de decisões em conjunto com a equipe de projeto. 
Esta seção buscou realizar uma análise da fase de projeto do processo no PDP, apresentando as características das unidades de análise, os detalhes do processo de desenvolvimento de produtos das empresas, e realizando uma análise comparativa entre a fase de projeto do processo das unidades de análise com a literatura. O próximo capítulo busca extrair os principais pontos conclusivos. 


\section{CONCLUSÕES E SUGESTÕES PARA TRABALHOS FUTUROS}

Após a análise dos resultados da parte empírica e as considerações finais que seguem neste capítulo, acredita-se ter atingido o objetivo geral e os específicos deste trabalho, de se obter uma caracterização geral do PDP e de verificar, com base na literatura, como a fase de projeto do processo no PDP está estruturada, e analisar a importância das variáveis com a fase de projeto do processo em duas unidades de análise do segmento de aços planos do setor siderúrgico brasileiro. Além disso, por meio da abordagem de estudo de caso, conseguiu-se identificar práticas organizacionais, relacionadas à literatura, focando na condução do desenvolvimento industrial do PDP e suas respectivas interfaces organizacionais, envolvendo as áreas de marketing, engenharia do produto e manufatura.

As macros fases propostas (que constam na Figura 18 de estrutura metodológica do trabalho no Capítulo 4) foram realizadas desde a elaboração do referencial teórico sobre o tema, passando pela investigação empírica e finalizando com a comparação das unidades de análise. Vale deixar em evidência, que a escolha da abordagem metodológica utilizada neste trabalho facilitou alcançar os objetivos propostos inicialmente.

No referencial teórico foi realizada uma busca ampla na literatura sobre o PDP, e delineado o contorno do tema de pesquisa "fase de projeto do processo no PDP". A principal dificuldade para realizar a revisão bibliográfica foi a limitação de publicações na literatura específica a fase de projeto do processo no PDP.

A investigação empírica foi dividida em dois momentos. No primeiro procurou-se obter uma visão geral do PDP das unidades de análise, focando nos seguintes tópicos: os tipos de projetos desenvolvidos; se o PDP está estruturado em fases; como são formados os times multidisciplinares; quais os papéis e divisão do trabalho do time; como são utilizados os métodos e técnicas de suporte ao PDP; quais os indicadores de desempenho e medidas de sucesso utilizadas no PDP; se existem práticas de aprendizagem e de melhoria contínua no PDP; quais os motivadores para desenvolver novos produtos; e se existe uma estratégia de mercado para o desenvolvimento de novos produtos.

No segundo momento, após obter-se uma caracterização do PDP das unidades de análise, partiu-se para a fase de projeto do processo no PDP, investigando como 
esta fase está estruturada, e qual a relação das variáveis identificadas na literatura com o projeto do processo, além de compreender como a alta gerência soluciona os problemas de interface organizacional.

As conclusões gerais mostram que relativamente, as unidades de análise apresentaram baixa intensidade de gastos em P\&D. Isto pode indicar que o setor siderúrgico é maduro em termos tecnológicos. As unidades de análise também mostraram um número relativamente pequeno de novos produtos desenvolvidos, e os resultados financeiros com o PDP são também relativamente baixos, de 0,64\% da receita líquida na Planta-1 e 1,21\% na Planta-2. Isso reflete o tipo de mercado em que as unidades de análise atuam, sendo que a Planta-1 com produtos de menor valor agregado e a Planta-2 com produtos de maior valor agregado, como aços galvanizados e revestidos. Entretanto, nota-se que o desenvolvimento de novos produtos apesar de ser de baixa intensidade é considerado estrategicamente importante para as unidades de análise satisfazerem às exigências dos clientes e manter a liderança no segmento de aços planos no mercado interno.

Quanto aos resultados empíricos cabe concluir primeiramente que os procedimentos adotados pelas unidades de análise na condução do PDP, estão alinhados entre si e com a literatura, pois utilizam de práticas padronizadas que auxiliam na estruturação do PDP, tais como: PDP dividido em fases e utilização de revisão de fases, estrutura matricial "peso leve", utilização de métodos e técnicas de suporte, integração das áreas envolvidas, utilização de equipes multidisciplinares, envolvimento da alta gerência, padronização de procedimentos, práticas de aprendizagem do time e de melhoria contínua.

Ainda sobre os resultados empíricos, porém, agora, referentes à fase de projeto do processo e suas variáveis. Destaca-se que na comparação entre as respostas dos questionários aplicados às unidades de análise, houve a mesma compreensão da importância das variáveis, para as mesmas áreas de cada unidade de análise, em relação à fase de projeto do processo. Entretanto, entre as diferentes áreas envolvidas no PDP (marketing, engenharia do produto e manufatura) houve discrepância na interpretação de importância das variáveis técnicas para 0 desenvolvimento de novos produtos.

É interessante ressaltar, que embora estudos tenham sido desenvolvidos para relacionar a influência de variáveis com o sucesso do PDP, há uma necessidade de prestar validação empírica, a fim de identificar com precisão se estes conceitos 
demonstram a realidade e identificar eventuais lacunas na literatura. Logo, este trabalho apresenta algumas conclusões das variáveis relacionadas à fase de projeto do processo, que estão associadas à estrutura organizacional empregada pelas unidades de análise, ou seja, do segmento de aços planos do setor siderúrgico, e que são discutidas a seguir:

- Trabalho em equipe/Integração de variáveis de processo

Conclui-se que o trabalho em equipe é fundamental para se conduzir a fase de projeto do processo, devido à natureza do processo siderúrgico, de ser uma empresa com grandes equipamentos, muito diferentes uns dos outros, que trabalham de forma seqüencial e integrada. Portanto, a utilização de uma estrutura matricial "peso leve" em conjunto com uma equipe multidisciplinar nesta etapa do desenvolvimento facilita o trabalho dos envolvidos, em termos de compartilhamento de conhecimentos e também como forma de integração das áreas envolvidas no PDP. Vale à pena destacar que é de suma importância que a equipe multidisciplinar tenha uma visão comum de todas as atividades do projeto do processo e suas respectivas variáveis, e compartilhe informações e recursos para se obter melhores resultados. Por isso, a importância da participação dos especialistas dos equipamentos, responsáveis pelas rotas de fabricação do novo produto, nas reuniões para expor as limitações de processo e acompanhar o desenvolvimento do produto nas suas respectivas áreas, assim se destaca também a importância da integração de variáveis de processo nesta fase do PDP.

- Métodos e técnicas de suporte ao projeto do processo

Conclui-se que as unidades de análise para controlar o projeto do processo, utilizam de indicadores de desempenho, medidas de sucesso e métodos e técnicas de suporte similares com a literatura sobre o assunto. Além disso, alguns métodos e técnicas de suporte ao projeto do processo, como FMEA, são exigidos pela indústria automobilística. Os indicadores de desempenho mais utilizados pelas unidades de análise são: a análise da lucratividade, o tempo gasto em cada fase do desenvolvimento, e o tempo real versus tempo planejado. Somando-se a estes indicadores existem as medidas de sucesso no projeto do processo, que são: o nível de desempenho do produto, as metas de margem, as metas de lucratividade, e percentual de vendas dos novos produtos. As unidades de análise utilizam ainda de métodos e técnicas de suporte que atendem as suas necessidades, sendo que os principais são: análise de mercado; análise de risco e potencial de falhas; análise de 
viabilidade técnica e econômica; análise de custo de fabricação; Análise dos Modos de Falha e seus Efeitos (FMEA); técnicas estatísticas e metalúrgicas; e Roteiro de Acompanhamento de Experiência (RAE).

- Aprendizagem do time/Padrões claros de condução do projeto do processo/Melhoria contínua

Conclui-se que nos quesitos de aprendizagem do time e padrões claros de condução da fase de projeto do processo, as unidades de análise são beneficiadas pela característica do setor siderúrgico de possuir todos os procedimentos normalizados, devido às exigências das certificações de qualidade, que exigem a documentação das atividades e o treinamento das pessoas envolvidas a cada modificação nos procedimentos. Adicionalmente, as unidades de análise possuem práticas de melhoria contínua no projeto do processo, que acontecem de duas maneiras em ambas as unidades de análise. Uma quando ocorrem dificuldades durante esta fase, que podem causar atrasos ou impedimentos ao andamento do processo, então se corrige os problemas e assim minimiza os seus possíveis efeitos ao longo do desenvolvimento industrial. A outra melhoria acontece quando o novo produto é implantado e ao se monitorar o seu desempenho e constatar-se um baixo rendimento, são feitos ajustes de conformidade e rendimento para posterior liberação como especificação automática.

- Produtividade do time

Conclui-se que, devido aos tipos de projetos desenvolvidos pelas duas unidades de análise serem derivativos ou de melhorias, as unidades de análise terem baixa quantidade de novos produtos desenvolvidos, e o tempo de desenvolvimento destes produtos serem relativamente longos, as medidas utilizadas para o controle da produtividade do time no projeto do processo estão alinhadas com a literatura e basicamente se relacionam em cumprir às condições estabelecidas na reunião de abertura do desenvolvimento de novo produto (prazo planejado, custo do produto, e resultados técnicos).

- Inovação tecnológica

O estado tecnológico dos equipamentos limita a fabricação de determinados 
produtos. Assim, o grau de inovação tecnológica ${ }^{29}$ é considerado crítico na fase de projeto do processo no setor siderúrgico. Isto se agrava com a baixa intensidade de gastos em P\&D apresentadas pelas unidades de análise. No entanto, identifica-se um acúmulo de competências tecnológicas inovadoras, quanto à capacidade de introduzir mudanças técnicas incrementais em processos de fabricação, desenvolvimento de produtos e melhoria do desempenho dos equipamentos. Este aumento constante de competências tecnológicas pode refletir os baixos investimentos em desenvolvimento de produtos e processo no setor siderúrgico. Somando-se a isso, o setor siderúrgico demonstra uma preocupação com a inovação tecnológica, destacando-se no depósito de patentes no Brasil.

A fim de encerrar a conclusão dos resultados empíricos, é importante destacar que devido à alta gerência ter atribuições de tomar decisões e solucionar problemas de interface organizacional no PDP, nunca houve necessidade de se interferir no andamento da fase de projeto do processo, pois o próprio gerente de projeto "peso leve" resolve estes problemas junto ao time de desenvolvimento. Como conseqüência, há indícios que as unidades de análise por terem o projeto do processo estruturado de forma matricial, com auxílio de sistemas informatizados, trabalho em equipe, e baseado em normas de qualidade, propicia à alta gerência tomar decisões em conjunto com a equipe de projeto.

Por fim, destaca-se que o acúmulo de competências tecnológicas na fase do desenvolvimento industrial do PDP é importante, principalmente em empresas que possuem muitas interfaces organizacionais e complexidades no processo de produção.

Finalizando este capítulo, é importante ressaltar que apesar de ter sido utilizada a observação direta como instrumento de coleta de dados, o autor por trabalhar em uma das unidades de análise, teve livre acesso a documentação e contato com as pessoas envolvidas no PDP, e assim obteve mais dados para análise e agilidade na execução da parte empírica do trabalho. No entanto, pelo mesmo motivo do autor trabalhar no setor siderúrgico, teve-se dificuldade para identificar o tema no escopo de trabalho profissional, e de como levar algumas questões técnicas da literatura de

${ }^{29}$ O conceito de grau de inovação tecnológica neste trabalho está ligado a transformações substanciais nos produtos, serviços e processos produtivos decorrentes da incorporação de novas tecnologias. De forma geral, essas mudanças podem vir da aquisição de bens de capital (máquinas, software de gestão etc.) que tragam melhorias intrínsecas, ou investimentos em P\&D, cujos resultados normalmente são mais diferenciados (ARRUDA et. al, 2006). 
PDP para este setor. Na próxima seção apresenta algumas limitações do presente trabalho e sugestões para trabalhos futuros.

\subsection{Sugestões para trabalhos futuros}

O desenvolvimento de novos produtos é um processo complexo e qualquer trabalho neste tema possui limitações. Este trabalho apresentou algumas limitações, a primeira foi devido às duas unidades de análise fazerem parte de uma mesma organização e terem o PDP padronizado, assim os resultados podem não ser conclusivos para uma generalização no segmento de aços planos do setor siderúrgico brasileiro. É interessante destacar também o baixo grau de intensidade tecnológica deste setor, quanto ao desenvolvimento de novos produtos. A segunda limitação foi a impossibilidade de se analisar todas as 32 variáveis encontradas na varredura vertical relacionadas ao projeto do processo citados no Capítulo 2 de referencial teórico, devido a quantidade de variáveis e ao tempo finito para se concluir esta pesquisa.

A análise dos resultados deste trabalho e as limitações citadas acima evidenciam algumas oportunidades para novos trabalhos sobre a condução do desenvolvimento industrial do PDP. Assim sendo, recomenda-se a realização de pesquisas envolvendo unidades de análise com maior grau de intensidade de inovação tecnológica, para verificar como se comporta a relação das variáveis da fase de projeto do processo em setores com maior geração de novos produtos e desenvolvimento de diferentes tipos de projetos (projetos de próxima geração ou plataforma; projetos de inovações radicais; projetos de P\&D avançado; e projetos de alianças ou parceria) e, assim, conseguir gerar conhecimentos para o tema desenvolvimento de novos produtos. Outro assunto, que merece ser pesquisado é a relação das normas de certificação ISO 9001 com o desenvolvimento de novos produtos, ou seja, se as normas de qualidade podem ser consideradas ferramentas de suporte ao PDP e se estruturam o processo para conseguir produtos novos de sucesso. Outro ponto importante identificado neste trabalho foi o acúmulo de competências tecnológicas pelas unidades de análise. Poderia aprofundar-se neste tema e verificar se há relação entre acúmulo de competência tecnológica e baixa intensidade de investimentos em P\&D. 


\section{REFERÊNCIAS BIBLIOGRÁFICAS}

ABDOMEROVIC, M.; BLAKEMORE, G. Project process interactions. International Journal of Project Management, v.20, n.4, p.315-323, 2002.

AKAO, Y. Quality function deployment: integrating customer requirements into product design. Trad. por Glenn H. Mazur, Cambridge, Productivity Press, 1990.

AKGUN, A. E. et al. Antecedents and consequences of unlearning in new product development teams. The Journal of Product Innovation Management, v.23, n.1, p.73-88, 2006.

ALTAMIRANO, A. V. Metodologia para integração do marketing e da manufatura. 245p. Tese (Doutorado) - Departamento de Engenharia de Produção e Sistemas, UFSC, Florianópolis, 1999.

AMARAL, D. C. Colaboração cliente fornecedor no desenvolvimento de produto: integração, escopo e qualidade do projeto do produto - estudo de caso da indústria automobilística brasileira. 192p. Dissertação (Mestrado) Departamento de Engenharia de Produção, UFSCar, São Carlos, 1997.

Arquitetura para gerenciamento de conhecimentos explícitos sobre o processo de desenvolvimento de produto. 229p. Tese (Doutorado) - UFSCar, São Carlos, 2002.

ANTONI, M. et al. Inter-project improvement in product development. International Journal of Quality \& Reliability Management, v.22, n.9, p.876-893, 2005.

APQP. Planejamento avançado da qualidade do produto e plano de controle. Instituto da Qualidade Automotiva, 1997.

ARRUDA, M. et al. Inovação tecnológica no Brasil: a indústria em busca da competitividade global. ANPEI, São Paulo, 2006.

ASSOCIAÇÃO NACIONAL DE PESQUISA, DESENVOLVIMENTO E ENGENHARIA DAS EMPRESAS INOVADORAS. Indicadores de pesquisa e desenvolvimento (P\&D): síntese dos resultados. ANPEI, São Paulo, abril 2007.

ASSOCIAÇÃO BRASILEIRA DE NORMAS TÉCNICAS. NBR ISO 9001: Sistema de gestão da qualidade - Requisitos. Rio de Janeiro, 2000.

NBR ISO TS 16949: Sistema de gestão da qualidade - Requisitos particulares para aplicação da NBR ISO 9001:2000 para organizações de produção automotiva e peças de reposição pertinentes. Rio de Janeiro, 2002.

NBR ISO 14001: Sistema de gestão ambiental - Especificação e diretrizes para uso. Rio de Janeiro, 2004. 
BARKAN, P. Productivity in the process of product development - an engineering perspective. In: Susman, G.I. (ed.) Integrate design for manufacturing for competitive advantage, New York, Oxford University Press, p.56-68, 1992.

BASSO, J. L. Engenharia e Análise do Valor. São Paulo: IMAM, 1991.

BONNER, J. M. et al. Upper management control of new product development projects and project performance. The Journal of Product Innovation Management, v.19, n.3, p.233-245, 2002.

BOOTHROYD, G. et al. Product Design for Manufacture and Assembly. New York: Marcel Dekker Inc., 1994.

BSTIELER, L.; GROSS, C. W. Measuring the effect of environmental uncertainty on process activities, project team characteristics, and new product success. The Journal of Business \& Industrial Marketing, v.18, n.2/3, p.146-161, 2003.

CARTER, D. E.; BAKER, B. S. Concurrent engineering: the product development environment for the 1990s. Reading, Addison-Wesley, 1992.

CHENG, L. C. Caracterização da gestão de desenvolvimento do produto: delineando o seu contorno e dimensões básicas. II Congresso brasileiro de gestão de desenvolvimento do produto. São Carlos, SP, 30 e 31 de agosto, 2000.

CHRONEER, D.; LAURELL-STENLUND, K. Organizational changes in product development in various process industries. Management of Engineering and Technology. PICMET, Portland International Conference, v.1, p.350, 2001.

CLARK, K. B.; FUJIMOTO, T. The power of product integrity. Harvard Business Review, 1990.

Product development performance: strategy, organization and management in the world auto industry. Boston-Mass. Harvard Business School Press, 1991.

CLARK, K. B.; WHEELWRIGHT, S. C. Revolutionizing product development: quantum leaps in speed, efficiency and quality. New York: The Free Press, 1992. Press, 1993.

. Managing new product and process development. New York: The Free

The product development challenge: competing through speed, quality and creativity. Harvard Business Review Book, Hardcover, 1995.

CLAUSING, D. Total quality development: a step-by-step guide to world-class concurrent engineering. New York: ASME Press, p.1-172, 1994.

COLENCI JR, A. Análise e engenharia de valor. São Carlos. Relatório técnico EESC-USP, 1989. 
COOPER, R. G. Winning at new products: accelerating the process from idea to launch. Reading: Perseus Books, 1993.

COOPER, R. G.; KLEINSCHMIDT, E. J. New product performance: what

distinguishes the star products. Australian Journal of Management, v.25, n.1, p.1725, 2000.

CORMICAN, K.; O'SULLIVAN, D. Auditing best practice for effective product innovation management. Technovation, v.24, n.10, p.819-829, 2004.

COSIPA. Relatório anual. São Paulo: Cosipa, 2006.

Normas operacionais e documentos complementares. São Paulo: Cosipa, 2007. 2007. Relatório de desenvolvimento de novos produtos. São Paulo: Cosipa,

COSTA SILVA, A. L. V. Gestão da qualidade para melhoria da eficiência em siderurgia. Contribuição apresentada no IX Encontro de Gestão de Qualidade, ABM, 30 e 31 de agosto, São Paulo, 2000.

CROOM, S. Topic Issues and methodological concerns for operations management research. EDEN Doctoral Seminar on Research Methodology in Operations Management, Brussels, Belgium, 31st Jan.-4th Feb, 2005.

CUNHA, G. D. Uma análise da evolução dos procedimentos de execução do desenvolvimento de produtos. Revista Produto \& Produção, Porto Alegre, v. 7, n. 1, 19p, 2004.

DA SILVA, M. M.; ALLIPRANDINI, D. H. Análise do processo de desenvolvimento de produto: estudo de caso em empresas manufatureiras baseado em um modelo referencial para caracterização e diagnóstico. II Congresso Brasileiro de Gestão de Desenvolvimento de Produto. São Carlos, 2000.

DOOLEY, K.; JOHNSON, D. Changing the new product development process: reengineering or continuous quality improvement? Measuring Business Excellence, v.5, n.4, p.32-38, 2001.

DRIVA, $\mathrm{H}$. et al. Measuring product development performance in manufacturing organizations. International Journal of Production Economics, v.63, n.2, p.147159, 2000.

EISENHARDT, K. M. Building theories from case study research. Academy of Management Review, v.14, n.4, p.535-550, 1989.

ESTORILIO, C. C. A. O trabalho dos engenheiros em situações de projeto de produto: uma análise de processo baseada na ergonomia. 317p. Tese (Doutorado) - USP, São Paulo, 2003. 
FAESSARELA, I. S. et al. Gestão de qualidade: conceitos e ferramentas. Universidade de São Paulo, Escola de Engenharia Mecânica, São Carlos, 1996.

FERRARI, F. M. et al. Ferramentas do processo de desenvolvimento de produto como mecanismos potencializadores da gestão do conhecimento. III Congresso Brasileiro de Gestão de Desenvolvimento de Produto. Florianópolis, 2001.

FLORENZANO, M. C. Gestão de desenvolvimento de produtos: estudo de casos na indústria brasileira de autopeças sobre a divisão de tarefas, capacidade e integração interunidades. 1999. 135p. Dissertação (Mestrado) Universidade Federal de São Carlos, São Carlos, 1999.

FREDERICKS, E. Cross-functional involvement in new product development. Qualitative Market Research: an International Journal, v.8, n.3, p.327-341, 2005.

FREITAS, C. Uma proposta de avaliação da reestruturação do processo de desenvolvimento de produtos baseada em métricas. 124p. Dissertação (Mestrado Profissionalizante) - UFRGS, Porto Alegre, 2004.

GARCIA, R.; CALANTONE, R. A critical look at technological innovation typology and innovativeness terminology: a literature review. Journal of Product Innovation Management, v.19, n.2, p.110-132, 2002.

GIL, A. C. Como elaborar projetos de pesquisa. São Paulo: Atlas, 1999.

GODOY, A. S. Introdução à pesquisa qualitativa e suas possibilidades. Revista de Administração de Empresas, v.35, n.2, p.57-63, 1995.

GOMES, F. M. História da siderurgia no Brasil. Belo Horizonte: ed. Itatiaia; São Paulo: Ed. da Universidade de São Paulo, 1983.

GRIFFIN, A.; PAGE, A. L. An interim report on measuring product development success and failure. Journal of Product Innovation Management, v.10, n.2, p.291308, sep. 1993.

GRIFFIN, A. PDMA research on new product development practices: updating trends and benchmarking best practices. Journal of Product Innovation Management, v.14, n.2, p.429-458, nov. 1997.

. The effect of project and process characteristics on product development cycle time. Journal of Marketing Research, v.34, n.1, p.24-35, 1997.

HAQUE, B. et al. The application of business process modelling to organisational analysis of concurrent engineering environments. Technovation, v.23, n.2, p.147162, 2003.

HART, C. Doing a literature search: a comprehensive guide for the social sciences. London. Sage Publications, 2001. 
HART, S. et al. Industrial company's evaluation criteria in new product development gates. Journal of Product Innovation Management, v.20, n.1, p.22-36, 2003.

HAUSER, J. R.; CLAUSING, D. The house of quality. Harvard Bussiness Review, n.3, p.63-73, 1988.

HOLMES, M. F.; CAMPBELL, R. B. Jr. Improving product development processes along three key vectors leads to greatly improved business performance. MIT Center for Innovation in Product Development Conference, p.117, 2002.

HUANG, X. Managing new product development in the chinese steel industry: an empirical investigation. International Journal Technology Management, v.24, n.5/6, p.557-568, 2002.

HULTINK, E. J.; ROBBEN, H. S. J. Measuring new product success: the difference that time perspective makes. Journal of Product Innovation Management, v.12, n.5, p.392-405, nov. 1995.

IBS. Instituto Brasileiro de Siderurgia. A siderurgia em números - pocket yearbook 2007. Rio de Janeiro: IBS, 2007.

Anuário estatístico da siderurgia brasileira. Rio de Janeiro: IBS, 2007.

Produtos desenvolvidos pela siderurgia nacional. Rio de Janeiro: IBS, 2007. Disponível em : <http:// www.ibs.org.br>. Acesso em: 2007, mar. 20.

KENNY, J. Effective project management for strategic innovation and change in an organizational context. Project Management Journal, v.34, n.1, p.43-53, 2003.

KIM, J.; WILEMON, D. Sources and assessment of complexity in NPD projects. R\&D Management, v.33, n.1, p.15-30, 2003.

KING, B. Better designs in the half the time: implementing QFD quality function deployment in América. 3.ed, Methuen, Goal/QPC, 1989.

KRISHNAN, V.; LOCH, C. H. A retrospective look at production and operations management articles on new product development. Production and Operations Management, v.14, n.4, p.433-441, 2005.

KRISHNAN, V.; ULRICH, K. T. Product development decisions: a review of the literature. Management Science, v.47, n.1, p.1-21, 2001.

LAGER, T. A structural analysis of process development in process industry. R\&D Management, v.32, n.1, p.87-95, 2002.

LAKATOS, E. M.; MARCONI, M. A. Metodologia científica. 2.ed., São Paulo, 1995. 
LARSEN, M.; KIM, J. Integrating statistics into product development. Quality Congress. ASQ World Conference on Quality and Improvement Proceedings, Milwaukee, p.549-560, 2001.

LESTER, D. H. Critical success factors for new product development. Research Technology Management, v.41, n.1, p.36-43, 1998.

LINT, O.; PENNINGS, E. The option approach to the new product development process: a case study at Philips electronics. R\&D Management, v.31, n.2, p.163172, 2001.

MALTZ, E. et al. Influencing R\&D/marketing integration and the use of market information by R\&D managers: intended and unintended effects of managerial actions. Journal of Business Research, v.52, n.1, p. 69-82, 2001.

MARCH-CHORDÀ, I. et al. Product development process in Spanish SMEs: an empirical research. Technovation, v.22, n.5, p.301-312, 2002.

MARCUS, P. F.; KIRSIS, K. M. Many questions, more answers: steel success strategies - Europe 2. Paris: World Steel Dynamics, 50p., 2004a.

MATTAR, F. N. Pesquisa de marketing: metodologia e planejamento. São Paulo: Atlas, 1996.

MAYS, N.; POPE, C. Qualitative research in health care. Londres: BMJ Publishing Group, 1996.

MIGUEL, P. A. C. Estudo de caso na engenharia de produção: estruturação e recomendações para sua condução. Produção, v.17, n.1, p.216-229, 2007.

MOURÃO, M. B. et al. Introdução à siderurgia. Associação brasileira de metalurgia e Materiais. São Paulo, 428p, 2007.

MUNDIM, A. et al. Aplicando o cenário de desenvolvimento de produtos em um caso prático de capacitação profissional. Gestão \& Produção, v.9, n.1, p.1-16, 2002.

NAMBISAN, S. Information systems as a reference discipline for new product development. MIS Quarterly, v.27, n.1, p.1-18, 2003.

NILSSON-WITELL, L. et al. Continuous improvement in product development: improvement programs and quality principles. The International Journal of Quality \& Reliability Management, v.22, n.8, p.753-768, 2005.

NOBELIUS, D. Linking product development to applied research: transfer experiences from an automotive company. Technovation, v.24, n.4, p.321-334, 2004.

O'CONNOR, P. Implementing a stage-gate process: a multi-company perspective. Journal of Product Innovation Management, v.11, n.3, p.183-200, 1994. 
OLIVEIRA, V. C. P. Relatório setorial preliminar do diretório da pesquisa privada no Brasil - setor: siderurgia. Araraquara e Campinas: DPP-FINEPGEEIN-DPCT, 2003.

Reestruturação setorial e capacitação tecnológica na indústria siderúrgica brasileira. 2004. 164p. Dissertação (Mestrado) - Instituto de Geociências, Unicamp, Campinas, 2004.

OZER, M. New product development in Asia: an introduction to the special issue. Industrial Marketing Management, v.35, n.3, p.252-261, 2006.

PAULA, G. M. Privatização e estrutura de mercado na indústria siderúrgica mundial. 1998. Tese (Doutorado) - Instituto de Economia, Universidade Federal do Rio de Janeiro, Rio de Janeiro, 1998.

. Dimensões da estratégia de internacionalização: o caso de quatro grupos siderúrgicos (Minimills). São Paulo: Capitol, 148p., 2001.

Estudo da competitividade de cadeias integradas no Brasil: impacto das zonas de livre comércio. 226p. Nota Técnica. Instituto de Economia, UNICAMP, Campinas, 2002.

Inovação tecnológica na siderurgia brasileira. Inovação. Uniemp, v.1, n.4, p.16-17, 2005.

PINHO, M. S. Reestruturação produtiva e inserção internacional da siderurgia brasileira. 2001. Tese (Doutorado) - Instituto de Economia, Unicamp, Campinas, 2001.

PINHO, M. S.; LOPES, A. L. Dinâmica tecnológica e internacionalização da siderurgia: oportunidades para indústria brasileira. In: FURTADO, J. (org.). Globalização das cadeias produtivas do Brasil. São Carlos: EdUFSCar, 2003.

PORTER, M. E. Vantagem competitiva: Criando e sustentando um desempenho superior. Rio de Janeiro: Campus, 1989.

PRANCIC, E.; MARTINS, R. A. Uma revisão teórica sobre a medição de desempenho do processo de desenvolvimento de produto. IV Congresso Brasileiro de Gestão de Desenvolvimento do Produto. Gramado, RS, 2003.

PRASAD, B. Concurrent engineering fundamentals: integrated product and process organization. New Jersey, Prentice Hall International Series, 1997.

PUENTE, J. et al. A decision support system for applying failure mode and effects analysis. International Journal of Quality \& Reliability Management, Bradford, v.19, n.2, p.137- 151, 2002.

PUGH, S. Total design: integrated methods for successful product engineering. Addison Wesley Pub. Co., 1991. 
Creating innovative products using total design: the living legacy of Stuart Pugh. Massachusetts: Addison-Wesley, 1996.

RIZZO, E. M. S. Introdução aos processos siderúrgicos. Associação brasileira de metalurgia e materiais. São Paulo, 150p., 2005.

ROZENFELD, $\mathrm{H}$. Para integrar a manufatura é importante o domínio dos business process. Máquinas e Metais, p.32-47, outubro 1996.

Reflexões sobre a manufatura integrada por computador. Manufatura de classe mundial: mitos \& realidade. São Paulo, 1996.

Modelo de referência para o desenvolvimento integrado de produtos. Encontro Nacional de Engenharia de Produção. Gramado, RS, 1997.

ROZENFELD, $\mathrm{H}$. et al. O processo de desenvolvimento de produtos. Revista Produtos \& Serviços, São Paulo, Banas, n.312, p.55-64, dez. 2000, (edição especial: Fábrica do futuro: entenda como sua indústria vai ser amanhã).

Gestão de desenvolvimento de produtos: uma referência para a melhoria do processo. São Paulo: Saraiva, 2006.

SANTOS, A. C.; FORCELLINI, F. A. O projeto do processo no PDP na indústria de alimentos. IV Congresso Brasileiro de Gestão de Desenvolvimento do Produto. Gramado, RS, 2003.

SELLTZ, C. et al. Métodos de pesquisa nas relações sociais. São Paulo: EDUSP, 1975.

SHANE, S. A.; ULRICH, K. T. Technological innovation, product development, and entrepreneurship in management science. Management Science, v.50, n.2, p.133144, 2004.

SILVA, S. L. Proposição de um modelo para caracterização das conversões do conhecimento no processo de desenvolvimento de produtos. 2002. 245p. Tese (Doutorado) - USP, São Carlos, 2002.

SONG, M.; NOH, J. Best new product development and management practices in the Korean high-tech industry. Industrial Marketing Management, v.35, n.3, p.262-278, 2006.

SOUSA MENDES, G. H.; TOLEDO, J. C. Uma visão dos principais arranjos organizacionais aplicados ao desenvolvimento de produto. IV Congresso Brasileiro de Gestão de Desenvolvimento do Produto. Gramado, RS, 2003.

SOUZA, R. Case research in operations management. EDEN Doctoral Seminar on Research Methodology in Operations Management, Brussels, Belgium, 31st Jan.4th Feb, 2005. 
STAMATIS, D. H. Failure Mode and Effect Analysis: FMEA from theory to execution. 2.ed. ASQC, Milwaukee: Quality Press, 2003, p.494.

SYAMIL, A. et al. Process performance in product development: measures and impacts. European Journal of Innovation Management, v.7, n.3, p.205-217, 2004.

SYAN, C. S. Introduction to concurrent engineering. In SYAN, C. S.; MENON, U. Concurrent engineering: concepts, implementation and practices. London, England, Chapman \& Hall, p.3-23, 1994.

TATIKONDA, M.V.; ROSENTHAL, S. R. Technology novelty, project complexity, and product development project execution success: a deeper look at task uncertainty in product innovation. IEEE Transactions on Engineering Management, v.47, n.1, p.74-87, 2000.

TATIKONDA, M. V.; MONTOYA-WEISS, M. M. Integrating operations and marketing perspectives of product innovation: The influence of organizational process factors and capabilities on development performance. Management Science, v.47, n.1, p.151-172, 2001.

THIA, C. W. et al. An exploratory study of the use of quality tools and techniques in product development. The TQM Magazine, v.17, n.5, p.406-424, 2005.

THIEME, R. J. et al. Project management characteristics and new product survival. The Journal of Product Innovation Management, v.20, n.2, p.104-119, 2003.

TONIOLI, J. N. A integração entre o processo de desenvolvimento de produto e o gerenciamento da cadeia de suprimentos e sua relação com o papel desempenhado pelo engenheiro de produto. 156p. Dissertação (Mestrado) USP, São Paulo, 2003.

UNIVERSIDADE DE SÃO PAULO. Escola Politécnica. Divisão de Biblioteca. Diretrizes para apresentação de dissertações e teses. Divisão de biblioteca da Epusp, 3.ed., 103p., São Paulo, 2006.

USIMINAS. Relatório anual. Belo Horizonte: Usiminas, 2006.

Contexto da siderurgia mundial e o posicionamento da siderurgia brasileira. São Paulo: Usiminas, 2006.

Normas operacionais e documentos complementares. Belo Horizonte: Usiminas, 2007.

. Relatório de desenvolvimento de novos produtos. Belo Horizonte: Usiminas, 2007.

VALERI, S.G. Estudo do processo de revisão de fases no processo de desenvolvimento de produtos em uma indústria automotiva. 109p. Dissertação (Mestrado) - USP, São Carlos, 2000. 
VAN OORSCHOT, K. E. et al. Field studies into the dynamics of product development tasks. International Journal of Operations \& Production Management, v.25, n.8, p.720-739, 2005.

VASCONCELLOS, E.; HEMSLEY, J.R. Estrutura das organizações: estruturas tradicionais, estruturas para inovação e estruturas matricial. São Paulo:

Pioneira, 218p., 2000.

VOSS, C. et al. Case Research in Operations Management. International Journal of Operations and Production Management, v.22, n.2, p.195-219, 2002.

WINNER, $R$. I. et al. The role of concurrent engineering in weapons system acquisition. IDA Report R-338. Alexandria, Institute of Defense Analysis, 1988.

YIN, R. K. Estudo de caso - planejamento e método. 2.ed. São Paulo: Bookman, 2001.

ZANCUL, E. S. et al. Organização do trabalho no processo de desenvolvimento de produtos: a aplicação da engenharia simultânea em duas montadoras de veículos. Gestão \& Produção, v.13, n.1, p.15-29, jan.-abr., 2006. 


\section{APÊNDICE A - Protocolo de pesquisa}

Este Apêndice contém a estruturação do protocolo de pesquisa, que está dividido em quatro etapas: visão global do projeto; procedimentos de campo; determinação das questões; e guia para elaboração da dissertação.

\section{Visão global do projeto}

O presente trabalho aborda a fase de projeto do processo no PDP no setor siderúrgico brasileiro. Pretende-se através do estudo de caso buscar as práticas de duas unidades de análise do segmento de aços planos, que apresentam complementos à literatura atual, focando na parte do desenvolvimento industrial de novos produtos, nos times envolvidos, na forma de tomada de decisão e nos critérios utilizados para avaliação dos resultados.

\section{Procedimentos de campo}

Após definido os casos a serem analisados, esta etapa inicia com o contato dos casos via telefone, procurando situar os responsáveis pelo PDP da unidade de análise quanto aos objetivos da pesquisa para, em seguida, enviar os questionários (Apêndice B, Apêndice $\mathrm{C}$, Apêndice $\mathrm{E}$ ) via e-mail ao responsável pelo PDP e solicitar que ele retransmita aos engenheiros das áreas envolvidas (marketing, engenharia do produto e manufatura) os questionários a serem respondidos. Depois de recebidas as respostas dos questionários, para finalizar a coleta de dados é realizada uma entrevista semi-estruturada com o responsável pelo PDP (superintendente de engenharia do produto) do caso analisado para verificar o alinhamento dos conceitos entre a hierarquia na empresa e esclarecer dúvidas. $\mathrm{Na}$ visita técnica para realizar a entrevista, é necessário aproveitar para fazer uma análise documental buscando informações referente a estruturação do PDP da unidade de análise e solicitar o questionário respondido ao PINTEC. 


\section{Determinação das questões}

O trabalho se concentra em um objetivo geral e dois específicos. O geral consiste em obter uma caracterização do PDP, e os específicos de verificar, com base na literatura, como a fase de projeto do processo no PDP está estruturada, e qual a importância de algumas variáveis (identificadas no Capítulo 2 de referencial teórico) nesta fase. $O$ trabalho pretende também identificar como são conduzidos os problemas de interface organizacional na fase de projeto do processo.

A fim de se atingir os objetivos específicos apontados, o presente trabalho pretende contribuir com respostas as seguintes questões de pesquisa:

- Como está estruturada a fase de projeto do processo em duas unidades de análise de empresa do segmento de aços planos do setor siderúrgico brasileiro?

- Qual a relação das variáveis consideradas importantes ao PDP com a fase de projeto do processo em duas unidades de análise de empresa do segmento de aços planos do setor siderúrgico brasileiro?

Para conseguirem dados que dêem subsídios para responder as questões acima, é preciso utilizar de forma conjunta quatro instrumentos para coleta de dados: análise documental; checar as normas de qualidade e procedimentos de execução de atividades do PDP; questionários, aplicar os Apêndices B, C e E aos engenheiros envolvidos com o PDP; entrevista, aplicar no nível de superintendência para verificar o alinhamento dos conceitos entre a hierarquia na unidade de análise e esclarecer dúvidas; e observação direta, visitar as áreas envolvidas e se possível participar de reuniões de desenvolvimento de novos produtos.

\section{Guia para a elaboração da dissertação}

Para facilitar na elaboração da dissertação, é viável enquanto se faz a coleta de dados já ir escrevendo de forma estruturada os dados obtidos e fazendo análises preliminares dos resultados obtidos, e conseqüentemente publicando-os. Lembrando que a dissertação deve ser elaborada de forma adequada e ter um esquema conceitual claro, que demonstre confiabilidade nos procedimentos para possibilitar repetibilidade da pesquisa, apresentando os mesmos resultados. 


\section{APÊNDICE B - Questionário para compreensão do Processo de Desenvolvimento de Produtos (PDP) ${ }^{30}$}

\section{Definição de Projeto}

1. De onde surgem as idéias e como são selecionadas as melhores?

2. Qual é o principal critério para aprovação do projeto?

3. Como está estruturada a definição do escopo, quanto aos participantes, quem decide e como é finalizado?

4. Existe uma estratégia para os produtos e como se relacionam a empresa?

5. Como é o gerenciamento do portfólio?

6. Quais são as metas do projeto?

\section{Organização do projeto}

1. Existe um gerente de projeto? Qual é o seu papel?

2. Como estão organizadas fisicamente as pessoas envolvidas no PDP?

3. Como é a hierarquia organizacional do projeto?

4. São formados times específicos? Como? Por quem?

5. Qual é o grau de autonomia das pessoas / times?

6. O pessoal é treinado? Qual é o nível exigido?

\section{Liderança e gerenciamento de projetos}

1. Existe um modelo para desenvolvimento de produtos?

2. Quais são as fases do PDP? Quais são os gates e quando ocorrem?

3. Quem são os responsáveis por tomada de decisão no PDP?

4. Qual é o papel dos gerentes funcionais, do gerente de processo e da gerência sênior (alta diretoria)?

5. Como são feitas as revisões de processo? Quais são os critérios para transição de fase?

\footnotetext{
${ }^{30}$ Adaptado do roteiro para compreensão do PDP utilizado no trabalho de: VALERI, S.G. Estudo do processo de revisão de fases no processo de desenvolvimento de produtos em uma indústria automotiva. 109p. Dissertação (Mestrado) - USP, São Carlos, 2000.
} 


\section{Resolução de problemas e testes}

1. Existe um procedimento para resolução de problemas? Se sim, como é? Quem? Quando?

2. Se não, como são resolvidos os problemas (quem, quando, autoridade)?

3. Como os protótipos são usados?

4. Quando e onde são feitos os testes pilotos?

\section{Revisão de gerência e controle}

1. Quando ocorrem as revisões de fase?

2. Existe um processo definido? Como é tomada a decisão?

3. Que critérios utilizam para a tomada de decisão? Está ligado à estratégia? Quais são os principais focos das revisões?

4. Existe diferença entre revisões técnicas e gerenciais?

5. Que gerentes decidem e em que fases?

6. Quem provém as informações para tomada de decisões?

7. Existe a possibilidade do projeto de ser parado?

\section{Correções}

1. Como são gerenciadas as mudanças de engenharia?

2. No caso de redirecionamento de projeto, como ocorre?

3. Como são resolvidos os conflitos interfuncionais?

4. Como são tratados os desvios de planejamento/prazos? 


\section{APÊNDICE C - Tabela para avaliação das principais variáveis}

\section{encontradas na literatura}

Grau de importância para a fase de projeto do processo no PDP: 0 - nenhuma relação, 1 - baixa relação, 3 - média relação, 9 - alta relação.

\begin{tabular}{|c|c|c|c|c|c|}
\hline \multicolumn{6}{|c|}{ ANALISADO PELA ÁREA COMERCIAL } \\
\hline \multirow{2}{*}{$\begin{array}{l}\text { PRINCIPAIS TÓPICOS ENCONTRADOS NA REVISÃO } \\
\text { BIBLIOGRÁFICA SOBRE PROCESSO DE } \\
\text { DESENVOLVIMENTO DE PRODUTOS }\end{array}$} & \multicolumn{4}{|c|}{ Fases do Processo de Desenvolvimento de Produtos } & \multirow[b]{2}{*}{ TOTAL } \\
\hline & $\begin{array}{l}\text { Desenvolvimento } \\
\text { do conceito }\end{array}$ & $\begin{array}{l}\text { Planejamento } \\
\text { do produto }\end{array}$ & $\begin{array}{l}\text { Engenharia do } \\
\text { produto/processo }\end{array}$ & $\begin{array}{c}\text { Produção } \\
\text { piloto/aumento da } \\
\text { produção }\end{array}$ & \\
\hline Ambiente de incerteza no PDP & 3 & 3 & 3 & 3 & 12 \\
\hline Aprendizagem do time no PDP & 9 & 9 & 9 & 9 & 36 \\
\hline Colaboração e comunicação no PDP & 9 & 9 & 9 & 9 & 36 \\
\hline Cumprimento de prazos no PDP & 3 & 9 & 9 & 9 & 30 \\
\hline Definição de responsabilidades no PDP & 9 & 3 & 3 & 3 & 18 \\
\hline Diretriz para gerentes de projeto & 9 & 9 & 9 & 9 & 36 \\
\hline Duração do ciclo de desenvolvimento de produtos & 9 & 9 & 9 & 9 & 36 \\
\hline Entender os problemas das áreas envolvidas no PDP & 9 & 9 & 9 & 9 & 36 \\
\hline Envolvimento da alta gerência no PDP & 9 & 9 & 9 & 9 & 36 \\
\hline Estratégia no PDP & 9 & 9 & 9 & 9 & 36 \\
\hline Evitar perda de conhecimento (experiência adquirida no PDP) & 9 & 9 & 9 & 9 & 36 \\
\hline Fatores de sucesso no PDP & 9 & 9 & 9 & 9 & 36 \\
\hline Gerenciamento de projetos & 9 & 9 & 9 & 9 & 36 \\
\hline Gestão do PDP & 9 & 9 & 9 & 9 & 36 \\
\hline Indicadores de desempenho & 3 & 9 & 9 & 9 & 30 \\
\hline Inovação tecnologica para PDP & 9 & 3 & 9 & 9 & 30 \\
\hline Integração do PDP & 9 & 9 & 9 & 9 & 36 \\
\hline Interação das variáveis de processo & 9 & 9 & 9 & 9 & 36 \\
\hline Mecanismo de controle da alta gerência para o PDP & 9 & 9 & 9 & 9 & 36 \\
\hline Melhoria contínua e performance no PDP & 9 & 9 & 9 & 9 & 36 \\
\hline Mudancas organizacionais no desenvolvimento de produtos & 3 & 3 & 3 & 3 & 12 \\
\hline Necessidade de padrões claros no PDP & 9 & 9 & 9 & 9 & 36 \\
\hline Planejamento de processo no PDP & 9 & 9 & 9 & 9 & 36 \\
\hline Processos de projeto e produto complexos & 9 & 9 & 9 & 9 & 36 \\
\hline Product development business process (integrando os & 9 & 9 & 9 & 9 & 36 \\
\hline Produtividade do time no PDP & 9 & 9 & 9 & 9 & 36 \\
\hline Sistema de informação no PDP & 9 & 9 & 9 & 9 & 36 \\
\hline Stage-Gate e revisão de fases & 9 & 9 & 9 & 9 & 36 \\
\hline Times multifuncionais no PDP & 3 & 9 & 9 & 9 & 30 \\
\hline Tomada de decisão no PDP & 9 & 9 & 9 & 9 & 36 \\
\hline Trabalho de equipe no PDP & 9 & 9 & 9 & 9 & 36 \\
\hline Utilização de ferramentas estatísticas no PDP & 9 & 9 & 9 & 9 & 36 \\
\hline TOTAL & 258 & 264 & 270 & 270 & 1062 \\
\hline
\end{tabular}

\begin{tabular}{|c|c|c|c|c|c|}
\hline \multicolumn{6}{|c|}{ ANALISADO PELA ÁREA DE ENGENHARIA DO PRODUTO } \\
\hline \multirow{2}{*}{$\begin{array}{c}\text { PRINCIPAIS TÓPICOS ENCONTRADOS NA REVISÃO } \\
\text { BIBLIOGRÁFICA SOBRE PROCESSO DE DESENVOLVIMENTO } \\
\text { DE PRODUTOS }\end{array}$} & \multicolumn{4}{|c|}{ Fases do Processo de Desenvolvimento de Produtos } & \multirow[b]{2}{*}{ TOTAL } \\
\hline & $\begin{array}{l}\text { Desenvolvimento } \\
\text { do conceito }\end{array}$ & $\begin{array}{l}\text { Planejamento } \\
\text { do produto }\end{array}$ & $\begin{array}{c}\text { Engenharia do } \\
\text { produto/processo }\end{array}$ & \begin{tabular}{|c|}
$\begin{array}{c}\text { Produção } \\
\text { piloto/aumento da } \\
\text { produção }\end{array}$ \\
\end{tabular} & \\
\hline Ambiente de incerteza no PDP & 3 & 3 & 1 & 1 & 8 \\
\hline Aprendizagem do time no PDP & 3 & 9 & 9 & 3 & 24 \\
\hline Colaboração e comunicação no PDP & 3 & 9 & 9 & 9 & 30 \\
\hline Cumprimento de prazos no PDP & 9 & 3 & 3 & 3 & 18 \\
\hline Definição de responsabilidades no PDP & 3 & 9 & 9 & 9 & 30 \\
\hline Diretriz para gerentes de projeto & 3 & 3 & 3 & 1 & 10 \\
\hline Duração do ciclo de desenvolvimento de produtos & 9 & 3 & 3 & 9 & 24 \\
\hline Entender os problemas das áreas envolvidas no PDP & 3 & 9 & 9 & 9 & 30 \\
\hline Envolvimento da alta gerência no PDP & 9 & 9 & 9 & 3 & 30 \\
\hline Estratégia no PDP & 9 & 1 & 1 & 1 & 12 \\
\hline Evitar perda de conhecimento (experiência adquirida no PDP) & 1 & 3 & 9 & 1 & 14 \\
\hline Fatores de sucesso no PDP & 3 & 9 & 3 & 1 & 16 \\
\hline Gerenciamento de projetos & 3 & 3 & 3 & 1 & 10 \\
\hline Gestão do PDP & 3 & 3 & 9 & 1 & 16 \\
\hline Indicadores de desempenho & 3 & 1 & 3 & 1 & 8 \\
\hline Inovação tecnologica para PDP & 3 & 3 & 3 & 9 & 18 \\
\hline \begin{tabular}{|l|} 
Integração do PDP \\
\end{tabular} & 0 & 1 & 1 & 1 & 3 \\
\hline Interação das variáveis de processo & 0 & 3 & 9 & 9 & 21 \\
\hline Mecanismo de controle da alta gerência para o PDP & 3 & 3 & 3 & 1 & 10 \\
\hline Melhoria contínua e performance no PDP & 3 & 9 & 9 & 1 & 22 \\
\hline Mudanças organizacionais no desenvolvimento de produtos & 3 & 3 & 3 & 0 & 9 \\
\hline Necessidade de padrões claros no PDP & 3 & 9 & 9 & 3 & 24 \\
\hline Planejamento de processo no PDP & 3 & 9 & 9 & 1 & 22 \\
\hline Processos de projeto e produto complexos & 1 & 1 & 1 & 1 & 4 \\
\hline Product development business process & 9 & 3 & 0 & 0 & 12 \\
\hline Produtividade do time no PDP & 9 & 9 & 9 & 3 & 30 \\
\hline Sistema de informação no PDP & 3 & 9 & 9 & 9 & 30 \\
\hline Stage-Gate e revisão de fases & 3 & 9 & 9 & 3 & 24 \\
\hline Times multifuncionais no PDP & 1 & 9 & 9 & 3 & 22 \\
\hline Tomada de decisão no PDP & 0 & 9 & 9 & 3 & 21 \\
\hline Trabalho de equipe no PDP & 9 & 9 & 9 & 9 & 36 \\
\hline Utilização de ferramentas estatísticas no PDP & 0 & 1 & 9 & 9 & 19 \\
\hline \begin{tabular}{|l|l|} 
TOTAL \\
\end{tabular} & 120 & 176 & 193 & 118 & 607 \\
\hline
\end{tabular}


ANALISADO PELA ÁREA DE MANUFATURA

\begin{tabular}{|c|c|c|c|c|c|}
\hline \multirow{2}{*}{$\begin{array}{c}\text { PRINCIPAIS TÓPICOS ENCONTRADOS NA REVISÃO } \\
\text { BIBLIOGRÁFICA SOBRE PROCESSO DE DESENVOLVIMENTO } \\
\text { DE PRODUTOS }\end{array}$} & \multicolumn{4}{|c|}{ Fases do Processo de Desenvolvimento de Produtos } & \multirow[b]{2}{*}{ TOTAL } \\
\hline & $\begin{array}{c}\text { Desenvolvimento } \\
\text { do conceito }\end{array}$ & $\begin{array}{c}\text { Planejamento } \\
\text { do produto }\end{array}$ & $\begin{array}{c}\text { Engenharia do } \\
\text { produto/processo }\end{array}$ & \begin{tabular}{|c|} 
Produção \\
piloto/aumento da \\
produção
\end{tabular} & \\
\hline Ambiente de incerteza no PDP & 9 & 9 & 1 & 1 & 20 \\
\hline Aprendizagem do time no PDP & 9 & 9 & 9 & 9 & 36 \\
\hline Colaboração e comunicação no PDP & 9 & 9 & 9 & 9 & 36 \\
\hline Cumprimento de prazos no PDP & 3 & 9 & 9 & 3 & 24 \\
\hline Definição de responsabilidades no PDP & 1 & 9 & 9 & 3 & 22 \\
\hline \begin{tabular}{|l} 
Diretriz para gerentes de projeto \\
\end{tabular} & 9 & 3 & 3 & 1 & 16 \\
\hline Duração do ciclo de desenvolvimento de produtos & 1 & 9 & 9 & 1 & 20 \\
\hline Entender os problemas das áreas envolvidas no PDP & 9 & 9 & 9 & 3 & 30 \\
\hline Envolvimento da alta gerência no PDP & 9 & 3 & 1 & 1 & 14 \\
\hline Estratégia no PDP & 1 & 9 & 9 & 3 & 22 \\
\hline Evitar perda de conhecimento (experiência adquirida no PDP) & 1 & 9 & 9 & 1 & 20 \\
\hline Fatores de sucesso no PDP & 9 & 9 & 9 & 9 & 36 \\
\hline Gerenciamento de projetos & 1 & 9 & 9 & 3 & 22 \\
\hline Gestão do PDP & 9 & 9 & 9 & 1 & 28 \\
\hline Indicadores de desempenho & 1 & 9 & 9 & 3 & 22 \\
\hline Inovação tecnologica para PDP & 1 & 1 & 9 & 9 & 20 \\
\hline Integração do PDP & 9 & 9 & 9 & 9 & 36 \\
\hline Interação das variáveis de processo & 1 & 9 & 9 & 3 & 22 \\
\hline Mecanismo de controle da alta gerência para o PDP & 9 & 9 & 3 & 1 & 22 \\
\hline Melhoria contínua e performance no PDP & 3 & 9 & 9 & 9 & 30 \\
\hline Mudanças organizacionais no desenvolvimento de produtos & 1 & 3 & 9 & 1 & 14 \\
\hline Necessidade de padrões claros no PDP & 9 & 9 & 9 & 9 & 36 \\
\hline Planejamento de processo no PDP & 3 & 9 & 3 & 3 & 18 \\
\hline Processos de projeto e produto complexos & 1 & 9 & 9 & 9 & 28 \\
\hline Product development business process & 9 & 3 & 9 & 1 & 22 \\
\hline Produtividade do time no PDP & 1 & 9 & 9 & 9 & 28 \\
\hline Sistema de informação no PDP & 9 & 3 & 9 & 1 & 22 \\
\hline Stage-Gate e revisão de fases & 3 & 3 & 9 & 1 & 16 \\
\hline Times multifuncionais no PDP & 9 & 3 & 9 & 1 & 22 \\
\hline Tomada de decisão no PDP & 3 & 9 & 9 & 1 & 22 \\
\hline Trabalho de equipe no PDP & 9 & 9 & 9 & 9 & 36 \\
\hline Utilização de ferramentas estatísticas no PDP & 9 & 3 & 9 & 1 & 22 \\
\hline TOTAL & 170 & 232 & 254 & 128 & 784 \\
\hline
\end{tabular}

PROCESSO DE DESENVOLVIMENTO DE PRODUTOS

\begin{tabular}{|c|c|c|c|c|}
\hline Principais Tópicos & MARKETING & $\begin{array}{l}\text { ENGENHARIA } \\
\text { DO PRODUTO }\end{array}$ & MANUFATURA & TOTAL \\
\hline Trabalho de equipe no PDP & 36 & 36 & 36 & 108 \\
\hline Colaboração e comunicação no PDP & 36 & 30 & 36 & 102 \\
\hline Aprendizagem do time no PDP & 36 & 24 & 36 & 96 \\
\hline Entender os problemas das áreas envolvidas no PDP & 36 & 30 & 30 & 96 \\
\hline Necessidade de padrões claros no PDP & 36 & 24 & 36 & 96 \\
\hline Produtividade do time no PDP & 36 & 30 & 28 & 94 \\
\hline Fatores de sucesso no PDP & 36 & 16 & 36 & 88 \\
\hline Melhoria contínua e performance no PDP & 36 & 22 & 30 & 88 \\
\hline Sistema de informação no PDP & 36 & 30 & 22 & 88 \\
\hline Duração do ciclo de desenvolvimento de produtos & 36 & 24 & 20 & 80 \\
\hline Envolvimento da alta gerência no PDP & 36 & 30 & 14 & 80 \\
\hline Gestão do PDP & 36 & 16 & 28 & 80 \\
\hline Interação das variáveis de processo & 36 & 21 & 22 & 79 \\
\hline Tomada de decisão no PDP & 36 & 21 & 22 & 79 \\
\hline Utilização de ferramentas estatísticas no PDP & 36 & 19 & 22 & 77 \\
\hline Planejamento de processo no PDP & 36 & 22 & 18 & 76 \\
\hline Stage-Gate e revisão de fases & 36 & 24 & 16 & 76 \\
\hline Integração do PDP & 36 & 3 & 36 & 75 \\
\hline Times multifuncionais no PDP & 30 & 22 & 22 & 74 \\
\hline Cumprimento de prazos no PDP & 30 & 18 & 24 & 72 \\
\hline Definição de responsabilidades no PDP & 18 & 30 & 22 & 70 \\
\hline Estratégia no PDP & 36 & 12 & 22 & 70 \\
\hline Evitar perda de conhecimento (experiência adquirida no PDP) & 36 & 14 & 20 & 70 \\
\hline Product development business process & 36 & 12 & 22 & 70 \\
\hline Gerenciamento de projetos & 36 & 10 & 22 & 68 \\
\hline Inovação tecnologica para PDP & 30 & 18 & 20 & 68 \\
\hline Mecanismo de controle da alta gerência para o PDP & 36 & 10 & 22 & 68 \\
\hline Processos de projeto e produto complexos & 36 & 4 & 28 & 68 \\
\hline Diretriz para gerentes de projeto & 36 & 10 & 16 & 62 \\
\hline Indicadores de desempenho & 30 & 8 & 22 & 60 \\
\hline Ambiente de incerteza no PDP & 12 & 8 & 20 & 40 \\
\hline Mudanças organizacionais no desenvolvimento de produtos & 12 & 9 & 14 & 35 \\
\hline TOTAL & 1062 & 607 & 784 & 2453 \\
\hline
\end{tabular}


FASE DE PROJETO DO PROCESSO

\begin{tabular}{|c|c|c|c|c|}
\hline Principais Tópicos & MARKETING & $\begin{array}{l}\text { ENGENHARIA } \\
\text { DO PRODUTO }\end{array}$ & MANUFATURA & TOTAL \\
\hline Colaboração e comunicação no PDP & 18 & 18 & 18 & 54 \\
\hline Trabalho de equipe no PDP & 18 & 18 & 18 & 54 \\
\hline Aprendizagem do time no PDP & 18 & 12 & 18 & 48 \\
\hline Entender os problemas das áreas envolvidas no PDP & 18 & 18 & 12 & 48 \\
\hline Inovação tecnologica para PDP & 18 & 12 & 18 & 48 \\
\hline Interação das variáveis de processo & 18 & 18 & 12 & 48 \\
\hline Necessidade de padrões claros no PDP & 18 & 12 & 18 & 48 \\
\hline Produtividade do time no PDP & 18 & 12 & 18 & 48 \\
\hline Melhoria contínua e performance no PDP & 18 & 10 & 18 & 46 \\
\hline Sistema de informação no PDP & 18 & 18 & 10 & 46 \\
\hline Utilização de ferramentas estatísticas no PDP & 18 & 18 & 10 & 46 \\
\hline Duração do ciclo de desenvolvimento de produtos & 18 & 12 & 10 & 40 \\
\hline Fatores de sucesso no PDP & 18 & 4 & 18 & 40 \\
\hline Stage-Gate e revisão de fases & 18 & 12 & 10 & 40 \\
\hline Times multifuncionais no PDP & 18 & 12 & 10 & 40 \\
\hline Tomada de decisão no PDP & 18 & 12 & 10 & 40 \\
\hline Evitar perda de conhecimento (experiência adquirida no PDP) & 18 & 10 & 10 & 38 \\
\hline Gestão do PDP & 18 & 10 & 10 & 38 \\
\hline Integração do PDP & 18 & 2 & 18 & 38 \\
\hline Processos de projeto e produto complexos & 18 & 2 & 18 & 38 \\
\hline Cumprimento de prazos no PDP & 18 & 6 & 12 & 36 \\
\hline Definição de responsabilidades no PDP & 6 & 18 & 12 & 36 \\
\hline Gerenciamento de projetos & 18 & 4 & 12 & 34 \\
\hline Indicadores de desempenho & 18 & 4 & 12 & 34 \\
\hline Planejamento de processo no PDP & 18 & 10 & 6 & 34 \\
\hline Envolvimento da alta gerência no PDP & 18 & 12 & 2 & 32 \\
\hline Estratégia no PDP & 18 & 2 & 12 & 32 \\
\hline Product development business process & 18 & 0 & 10 & 28 \\
\hline Diretriz para gerentes de projeto & 18 & 4 & 4 & 26 \\
\hline Mecanismo de controle da alta gerência para o PDP & 18 & 4 & 4 & 26 \\
\hline Mudanças organizacionais no desenvolvimento de produtos & 6 & 3 & 10 & 19 \\
\hline Ambiente de incerteza no PDP & 6 & 2 & 2 & 10 \\
\hline TOTAL & 540 & 311 & 382 & 1233 \\
\hline
\end{tabular}




\section{APÊNDICE D - Roteiro de entrevista não-estruturada}

O roteiro apresentado abaixo foi utilizado na condução da entrevista nãoestruturada, efetuada com o superintendente de engenharia de produto, para verificar o alinhamento dos conceitos sobre a fase de projeto do processo entre a hierarquia na empresa e esclarecer dúvidas.

Questões Gerais:

1. Qual é a questão fundamental do PDP no setor siderúrgico? É organizacional ou estratégica?

$\checkmark$ Como a estrutura organizacional/estratégica do PDP se mobiliza?

$\checkmark$ Como é realizada a liderança e capacitação no PDP?

$\checkmark$ Quais os métodos e técnicas de suporte ao PDP que são utilizados?

Questões específicas à fase de Projeto do Processo:

2. Qual a vantagem de se ter uma equipe de desenvolvimento dividida por tipos de produtos/processos?

3. Quais as vantagens/desvantagens de se trabalhar com uma estrutura organizacional do tipo "peso leve"?

4. Como é realizado o processo de aprendizagem do time envolvido na fase de Projeto do Processo?

5. Como é medida a produtividade dos envolvidos no time multidisciplinar?

6. A característica de processo contínuo do setor siderúrgico facilita a integração e o entendimento das limitações das áreas envolvidas na fase de projeto do processo?

7. As reuniões de PDP facilitam a integração das áreas envolvidas e solução de problemas?

8. Como é feita a tomada de decisões na fase de projeto de Processo? Quem é o responsável pela tomada de decisões?

9. Há práticas de melhoria contínua e/ou performance na fase de Projeto do Processo?

10. As normas de qualidade e documentos complementares que estruturam o PDP, qual é a principal finalidade destes documentos (Padronização)?

11. Quais são os fatores utilizados que determinam o sucesso e/ou fracasso na condução da fase de Projeto do Processo? Por quê? 


\section{APÊNDICE E - Questionário para análise da fase de projeto do processo no PDP}

\section{Projeto do Processo}

1. O que você entende pela fase de Projeto do Processo no desenvolvimento de produtos? Quais as etapas e atividades que fazem parte desse processo?

2. Como está estruturada a gestão da fase de Projeto do Processo?

3. Quais são as atividades e responsabilidades de sua área na fase de Projeto de Processo?

4. São formados times específicos para a fase de Projeto do Processo? Como são estruturados e conduzidos?

5. Como acontece a integração interfuncional das áreas envolvidas na fase do Projeto do Processo?

6. Como é realizado o processo de aprendizagem do time envolvido na fase de Projeto do Processo?

7. Tem algum acompanhamento da produtividade dos times? Quais são?

8. Como são analisados e solucionados os problemas/dificuldades de interações das equipes envolvidas na fase de Projeto do Processo?

9. Como é feita a colaboração e comunicação entre os envolvidos na fase de Projeto do Processo? Tem algum coordenador e/ou procedimento?

10. A fase de Projeto do Processo está devidamente documentada e acessível? Como é realizada a documentação e onde fica disponível para consulta?

11. Existem padrões claros para condução da fase de Projeto do Processo? Como é elaborada essa padronização?

12. Como acontece a interação das variáveis de processo envolvidas na fase de Projeto do Processo?

13. Como é feita a tomada de decisões na fase de Projeto de Processo? Quem é o responsável pela tomada de decisões?

14. Existe envolvimento da alta gerência nesta fase de Projeto do Processo? Como e quando acontece?

15. Quais são os fatores utilizados que determinam o sucesso e/ou fracasso na condução da fase de Projeto do Processo? Por quê? 
16. Há alguma prática de melhoria contínua e/ou performance na fase de Projeto do Processo? Cite as mais importantes?

17. São utilizados indicadores de performance para a fase de Projeto do Processo? Quais e como são utilizados?

18. É utilizado algum sistema de tecnologia de informação na fase de Projeto do Processo? Qual? Quais os benefícios dessa ferramenta?

19. Qual a influência da inovação tecnológica no Projeto do Processo? 
ANEXO A - Etapas do processo de fabricação de aços planos das unidades de análise

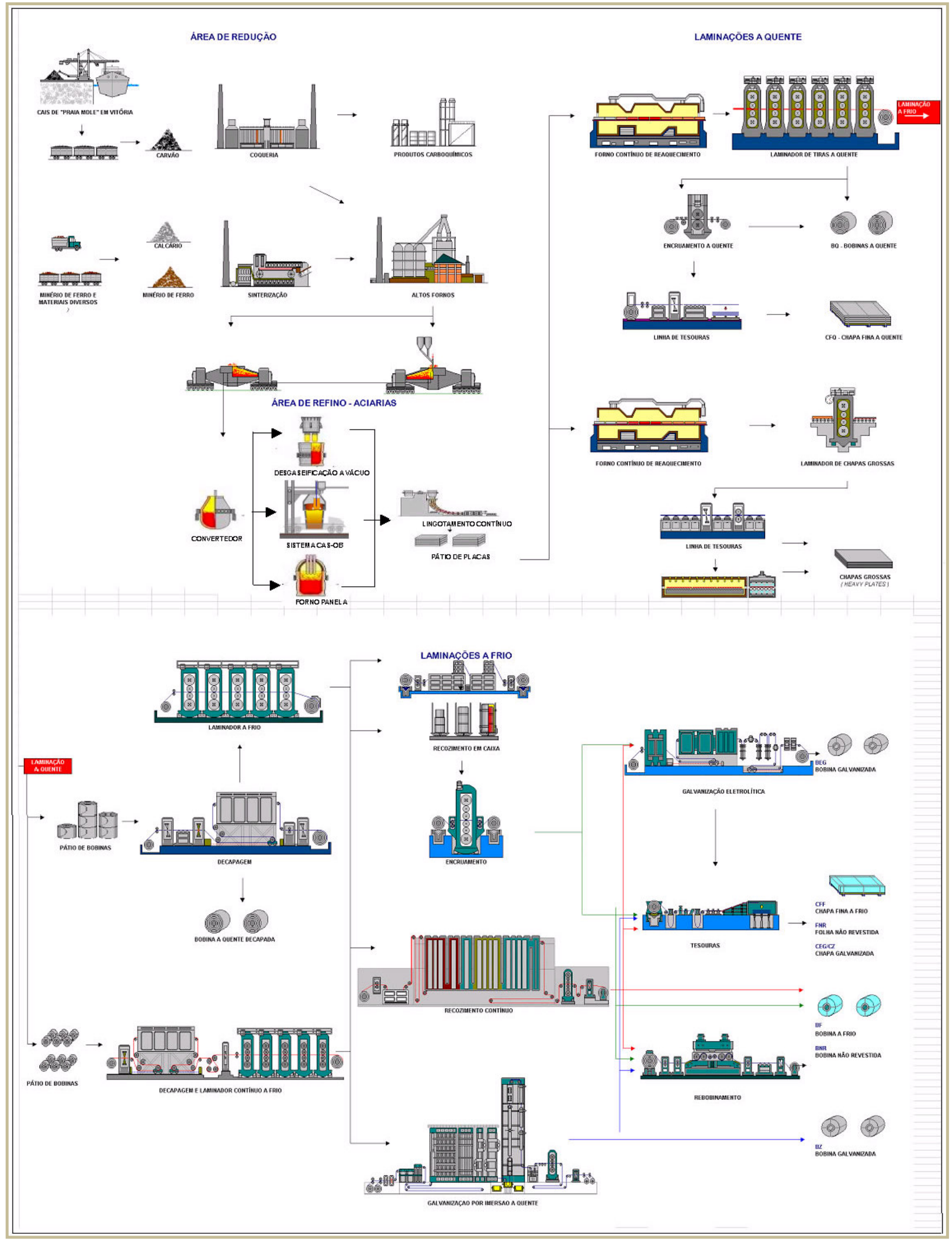




\section{ANEXO B - Roteiro de Acompanhamento de Experiência (RAE)}

Os dados de entrada de um projeto são analisados pela unidade responsável pela sua coordenação, os projetos são discutidos com as áreas operacionais para elaboração do experimento em escala industrial, assumindo uma das seguintes denominações: Roteiro de Acompanhamento de Experiências (RAE); Plano de Estudo (PE); Projeto de Qualidade (PQ); e Prática Operacional (PO).

Os planos de experimento são registrados com a sua sigla (RAE, PE, PQ ou PO), seguida de uma letra complementar que indica a linha de fabricação do produto ( $G$, $Q$ ou $F$, para indicar chapas grossas, tiras laminadas a quente e tiras laminadas a frio, respectivamente) e um conjunto de dois números separados por barra, sendo que o primeiro número indica a ordem, crescente e reiniciada anualmente e 0 segundo número indica o ano de início do projeto.

Os planos de experimento devem conter os seguintes itens quando apropriados:

$\checkmark$ Objetivo da experiência;

$\checkmark$ Aplicação do produto, devendo-se destacar quando este se destina à fabricação de peça que exigir segurança em trabalho;

$\checkmark$ Dados dos pedidos utilizados no experimento;

$\checkmark$ Norma de especificação de qualidade;

$\checkmark$ Aspectos dimensionais do produto;

$\checkmark$ Propriedades mecânicas objetivadas;

$\checkmark$ Composição química objetivada;

$\checkmark$ Condições de processo;

$\checkmark$ Condições de amostragem;

$\checkmark$ Ensaios químicos, mecânicos e metalográficos;

$\checkmark$ Áreas, pessoal envolvido e suas atribuições. 